\title{
A survey of the East Palaearctic Lycosidae (Aranei). 8. The genera Pirata Sundevall, 1833 and Piratula Roewer, 1960 in the Russian Far East
}

\author{
Обзор восточно-палеарктических пауков-волков (Aranei: \\ Lycosidae). 8. Рода Pirata Sundevall, 1833 и Piratula Roewer, 1960 \\ в фауне Аальнего Востока России
}

\author{
Mikhail M. Omelko, ${ }^{1,2}$, Yuri M. Marusilk ${ }^{3}$ \& Seppo Koponen ${ }^{4}$ \\ М.М. Омелько ${ }^{1,2}$, Ю.М. Марусик ${ }^{3}$, С. Копонен ${ }^{4}$
}

\footnotetext{
${ }^{1}$ Gornotayezhnaya Station FEB RAS, Gornotayezhnoe Vil., Ussuriyski Dist., Primorski krai 692533 Russia. E-mail: omelkom@gmail.com

${ }^{2}$ Far Eastern Federal University, Sukhanova 8, Vladivostok 690950 Russia.

${ }^{3}$ Institute for Biological Problems of the North, Portovaya Str. 18, Magadan 685000 Russia. E-mail: yurmar@mail.ru

${ }^{4}$ Zoological Museum, University of Turku, FI-20014 Turku Finland. E-mail: sepkopo@utu.fi

${ }^{1}$ Горнотаёжная станция ДВО РАН, с. Горнотаёжное, Уссурийский район, Приморский край 692533 Россия.

2 Дальневосточный Федеральный университет, Суханова 8, Владивосток 690950 Россия.

${ }^{3}$ Институт Биологических Проблем Севера ДВО РАН, ул. Портовая 18, Магадан 685000, Россия.

${ }^{4}$ Зоологический музей, университет Турку, FI-20014 Турку, Финляндия.
}

KEY WORDS: Aranei, wolf spiders, Siberia, Primorski krai, new species, new synonymy, new combination. КЛЮЧЕВЫЕ СЛОВА: Aranei, пауки-волки, Сибирь, Приморье, новый вид, новый синоним, новая комбинация.

ABSTRACT. Spiders belonging to Pirata from the Russian Far East have been surveyed and 14 species are illustrated. Morphological analysis of the northern Holarctic species of Pirata revealed that the genus Piratula can be removed from synonymy with Pirata. New diagnoses are provided for the two genera. Species and genus specific characters were surveyed. Twenty-five species occurring in the northern Holarctic are transferred into Piratula and 22 new combinations are established: Piratula hygrophila (Thorell, 1872), P. borea (Tanaka, 1974) comb.n., P. canadensis (Dondale \& Redner, 1981) comb.n., P. cantralli (Wallace \& Exline, 1978) comb.n., P. clercki (Bösenberg \& Strand, 1906) comb.n., $P$. denticulata (Liu, 1987) comb.n., $P$. gigantea (Gertsch, 1934) comb.n., P. hiroshii (Tanaka, 1986) comb.n., P. hokkaidensis (Tanaka, 2003) comb.n., P. hurkai (Buchar, 1966) comb.n., P. insularis (Emerton, 1885) comb.n., P. iriomotensis (Tanaka, 1989) comb.n., P. knorri (Scopoli, 1763), P. latitans (Blackwall, 1841), P. longjiangensis (Yan et al., 1997) comb.n., P. meridionalis (Tanaka, 1974) comb.n., P. minuta (Emerton, 1885) comb.n., P. montigena (Liu, 1987) comb.n., P. piratoides (Bösenberg \& Strand, 1906) comb.n., P. procurva (Bösenberg \& Strand, 1906) comb.n., P. serrulata (Song \& Wang, 1984) comb.n., P. tanakai (Brignoli, 1983) comb.n., P. tenuisetacea (Chai, 1987) comb.n., P. yaginumai (Tanaka, 1974) comb.n. and P. yesoensis (Tanaka, 1985) comb.n. It is highly likely that the southern Nearctic genus Sosilaus
Simon, 1898 should also be removed from synonymy with Pirata.

Two African species were transferred from Pirata to Trochosa: Trochosa fabella (Karsch, 1879), comb.n. and Trochosa mossambicus (Roewer, 1960), comb.n. Three species names are synonymized with Pirata subpiraticus (Bösenberg \& Strand, 1906): P. haploapophysis Chai, 1987, syn.n., P. blabakensis Barrion \& Litsinger, 1995, syn.n. and P. luzonensis Barrion \& Litsinger, 1995, syn.n. Pirata zelotes Wallace \& Exline, 1978 is synonymised with $P$. praedo Kulczyński, 1885. One new species, Piratula logunovi sp.n. is described from Maritime Province, Russia. One species of Pirata (P. subpiraticus) and three species of Piratula ( $P$. canadensis, $P$. piratoides and $P$. tanakai) are reported from Russia for the first time.

РЕЗЮМЕ. Сделан обзор видов рода Pirata с Дальнего Востока, 14 видов проиллюстрированы. Морфологический анализ видов, рассматриваемых в роде Pirata из северной Голарктики, показал, что род Piratula может быть убран из синонимии с Pirata. Даны новые диагнозы для этих родов. Рассмотрены родовые и видовые признаки. 25 видов из северной Голарктики перемещены в Piratula и установлено 22 новых комбинации. Два африканских вида перемещены из Pirata в Trochosa: Trochosa fabella (Karsch, 1879), comb.n., Trochosa mossambicus (Roewer, 1960), comb.n. Три вида синонимизиро- 
ванны с Pirata subpiraticus (Bösenberg \& Strand, 1906): P. haploapophysis Chai, 1987, syn.n., P. blabakensis Barrion \& Litsinger, 1995, syn.n. and $P$. luzonensis Barrion \& Litsinger, 1995, syn.n. Pirata zelotes Wallace \& Exline, 1978 синонимизирована с P. praedo Kulczyński, 1885. Один новый вид Piratula logunovi sp.n. описан из Приморского края. Один вид из рода Pirata (P. subpiraticus) и три вида рода Piratula впервые указаны для фауны России: $P$. canadensis, $P$. piratoides and $P$. tanakai.

\section{Introduction}

Pirata Sundevall, 1833 s. lat. is one of the most species-rich genera of lycosid spiders with 90 species distributed globally except for the Australasian region and Antarctica [Platnick, 2011]. Most of the species (ca. 60) are restricted to the Holarctic. Thirteen species are known from Europe (including some misplaced taxa), about 25 are restricted to the Nearctic region, and 28 species occurs in the south-east Palaearctic (China, Japan, Korea and the Russian Far East) [cf. Platnick, 2011].

The genus has never received a worldwide revision. The most comprehensive study was by Wallace \& Exline [1978] who revised all the Nearctic species. Unfortunately the quality of their illustrations (black and white photographs) was not very good. Regional revisions include Japanese taxa [Tanaka, 2009], and data concerning Chinese Pirata were summarized in Song et al. [1999] (although one species was overlooked).

Taxonomically, species attributed to the genus are rather well studied in Europe thanks to numerous publications including identification guides. It is also well studied in northern North America due to the monographs by Dondale \& Redner [1990] and Paquin \& Dupérré [2003].

The highest species diversity of Pirata s. lat. occurs in the southeastern part of the Palaearctic. Within a relatively small territory (Japan, Korea, northeastern China and the southern part of the Russian Far East) more than 25 species have been reported [Song et al., 1999; Marusik, 2007; Tanaka, 2009], with most of them being endemic. Unfortunately, many of these species are known only from their original descriptions and figures, which have been reproduced from one publication to the next. These figures lack many details in the shape of the tegular apophysis. The embolic division is illustrated only for a few of the species, and the illustrations of the epigynes of most species are very schematic. These do not facilitate identification of the species with any degree of confidence. Because Pirata species are rather common in the Russian Far East and because their identification is rather difficult, in part for the reasons discussed above, we decided to undertake this study, the main goals of which were to determine how many species occur in the region and to illustrate the important taxonomic features using SEM and digital photography.

\section{Material and methods}

The material treated here was largely collected by the authors in Maritime Province (Russia).

Specimens were photographed using an Olympus Camedia E-520 camera attached to an Olympus SZX16 stereomicroscope. The images were montaged using "CombineZM" image stacking software. Photographs were taken in dishes of different size with paraffin at the bottom. Different sized holes were made in the bottom to keep the specimens in the correct position. Figures had been made previously and in some instances we were unable to make scale bars.

For most species chaetotaxy of leg I was examined in 3-4 specimens of both sexes except for Pirata subpiraticus (1 female studied), P. tenuitarsis (1 female studied), Piratula borea (1 male and 2 females studied), P. logunovi (1 female studied), P. tanakai (1 male studied).

Abbreviations used in the figures:

$A a$ - apical arm; Co - conductor; $B a$ - basal arm; Bt - basal tooth of Ta; Em - embolus; It inner tooth of $\mathrm{Ta} ; \mathrm{Ms}$ - marginal stripe; Ot - outer tooth of $\mathrm{Ta} ; \mathrm{Pt}$ - pocket of tegular apophysis; $\mathrm{Sa}$ subterminal apophysis; $S m$ — submarginal stripe; $S t$ subtegulum; $S d$ - seminal duct; $T a$ - tegular apophysis; $T p$ — terminal apophysis.

Abbreviations used for museums:

GTS - Gornotayezhnaya Station, Gornotayezhnoye Vil., Russia; IBPN - Institute for Biological Problems of the North, Magadan, Russia; MCZ Museum of Comparative Zoology, Harvard University, USA; MMUM — the Manchester Museum, the University of Manchester, UK; ZMMU - Zoological Museum of the Moscow State University, Russia; ZMUT Zoological Museum, University of Turku, Finland.

\section{Taxonomic survey}

Taxonomic significance of the morphological characters in Pirata and Piratula.

SOMATIC CHARACTERS. Size. The two genera have barely any overlap in the length of the carapace, length of femur I, or carapace/femur I ratio (Figs 178179). Most specimens of Pirata have a longer carapace and femur I (cf. Figs 178-179). All Piratula examined had a carapace shorter than $3 \mathrm{~mm}$, while most of the Pirata had a carapace longer than $3 \mathrm{~mm}$.

Carapace. In some cases the pattern on the carapace can be used as additional criterion for species separation, and also to some extent for the separation of the genera. For example, Pirata piraticus (Figs 9-10) has no marginal dark stripes (only rarely do a few specimens have such stripes), while dark stripes are always present in $P$. praedo (Figs 21-22). P. subpiraticus lacks marginal dark stripes also (Figs 30-31). Marginal dark stripes in Piratula are always broader than in Pirata praedo. Piratula species may differ by having a darker cephalic region, or in the relative width of the submarginal light stripes. 


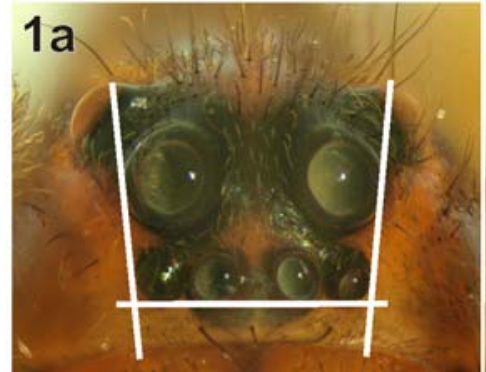

piraticus

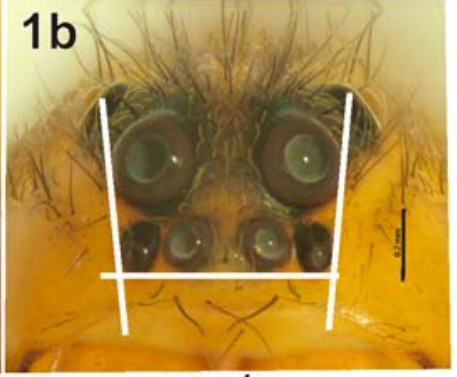

praedo

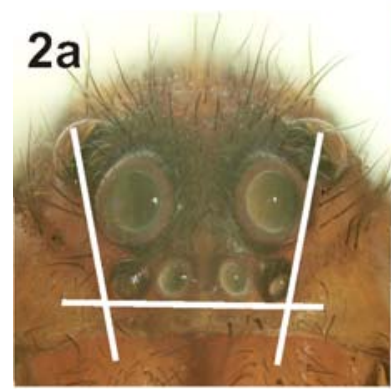

hygrophila

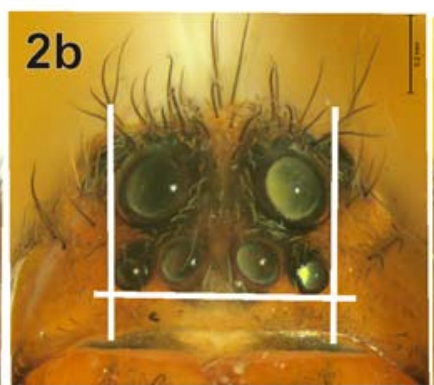

piratoides

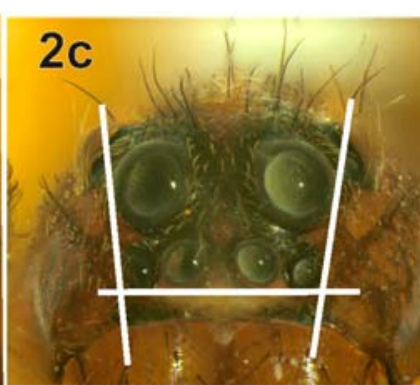

yaginumai

Figs 1-2. Eye arrangement of Pirata piraticus (1a), P. praedo (1b), Piratula hygrophila (2a), P. piratoides (2b) and P. yaginumai (2c). Рис. 1-2. Расположение глаз у Pirata piraticus (1a), P. praedo (1b), Piratula hygrophila (2a), P.piratoides (2b) и P. yaginumai (2c).

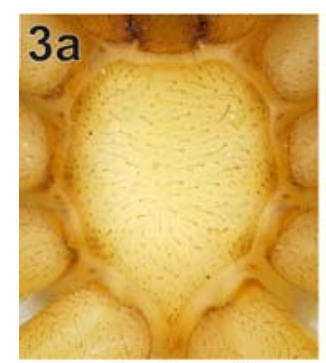

piraticus $\sigma^{\pi}$

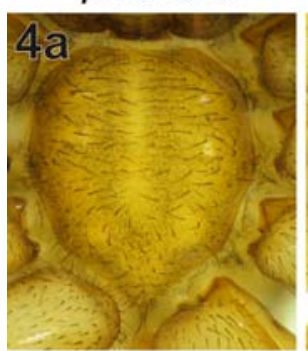

logunovi sp.n. $\sigma^{\pi}$

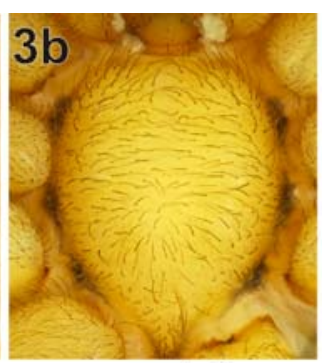

praedo $0^{\pi}$

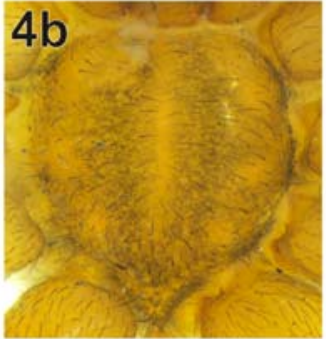

canadensis $\widehat{\sigma}$

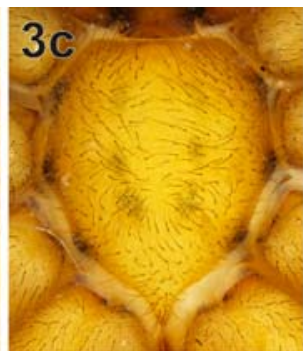

praedo우

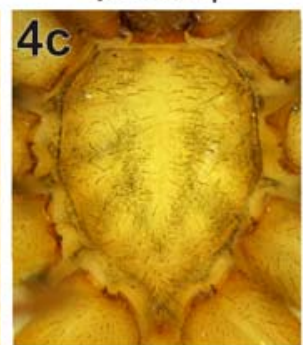

meridionalis $\sigma^{*}$

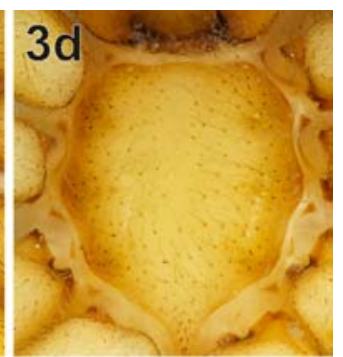

subpiraticus $\widehat{\sigma}$

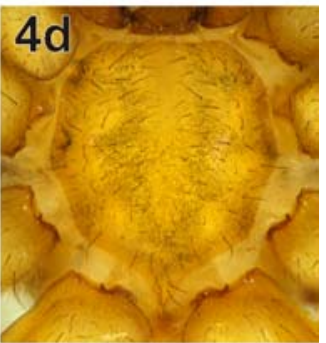

meridionalis +

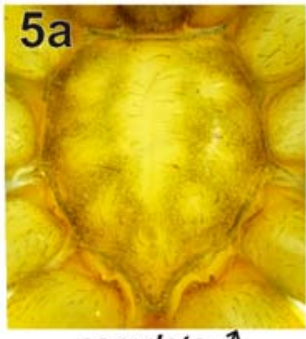

serrulata $\sigma^{\star}$

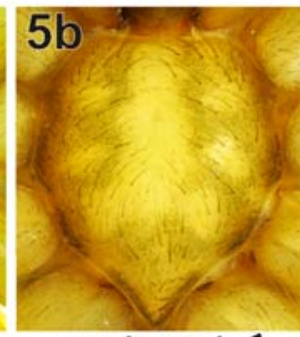

yaginumai $\sigma^{*}$

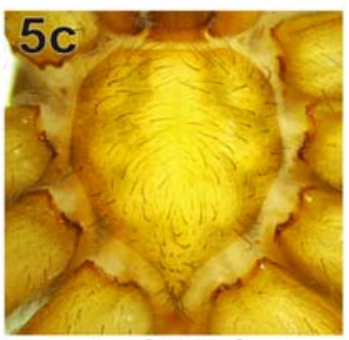

yaginumai 우

Figs 3-5. Sternums of Pirata piraticus (3a), P. praedo (3b-c), P. subpiraticus (3d), Piratula logunovi sp.n. (4a), P. canadensis (4b), P. meridionalis (4c-d), P. serrulata (5a) and P. yaginumai (5b-c).

Рис. 3-5. Стернумы Pirata piraticus (3a), P. praedo (3b-c), P. subpiraticus (3d), Piratula logunovi sp.n. (4a), P. canadensis (4b), P. meridionalis $(4 \mathrm{c}-\mathrm{d})$, P. serrulata $(5 \mathrm{a})$ и $P$. yaginumai $(5 \mathrm{~b}-\mathrm{c})$. 

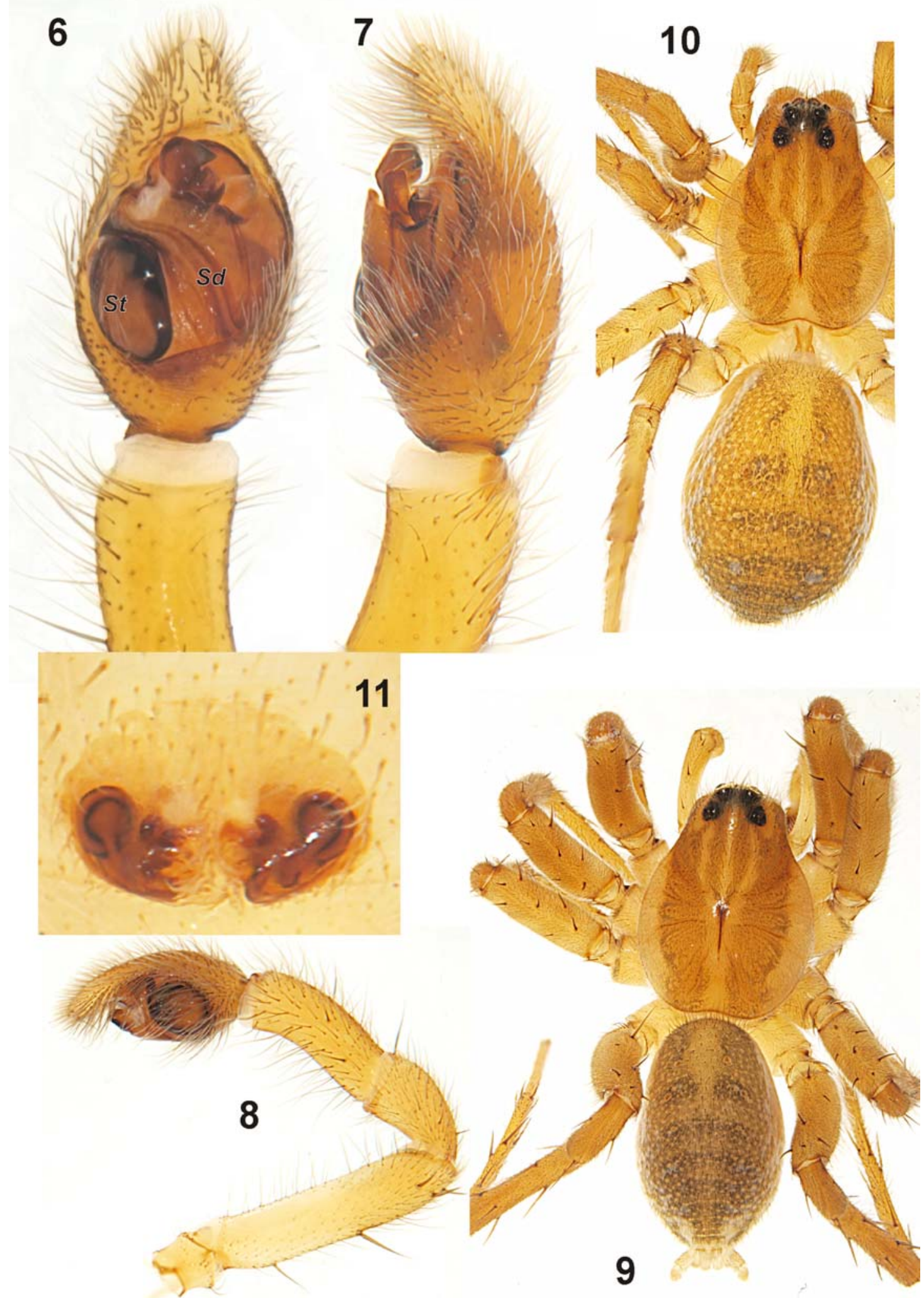

Figs 6-11. Pirata piraticus: 6 - palp, ventral view, 7 - palp, retrolateral view; 8 - whole palp; 9 - general appearance of male; 10 - general appearance of female; 11 - epigyne, ventral view.

Pис. 6-11. Pirata piraticus: 6 - пальпа, вентрально, 7 - пальпа, ретролатерально; 8 - пальпа целиком; 9 - внешний вид самца; 10 - внешний вид самки; 11 - эпигина, вентрально. 

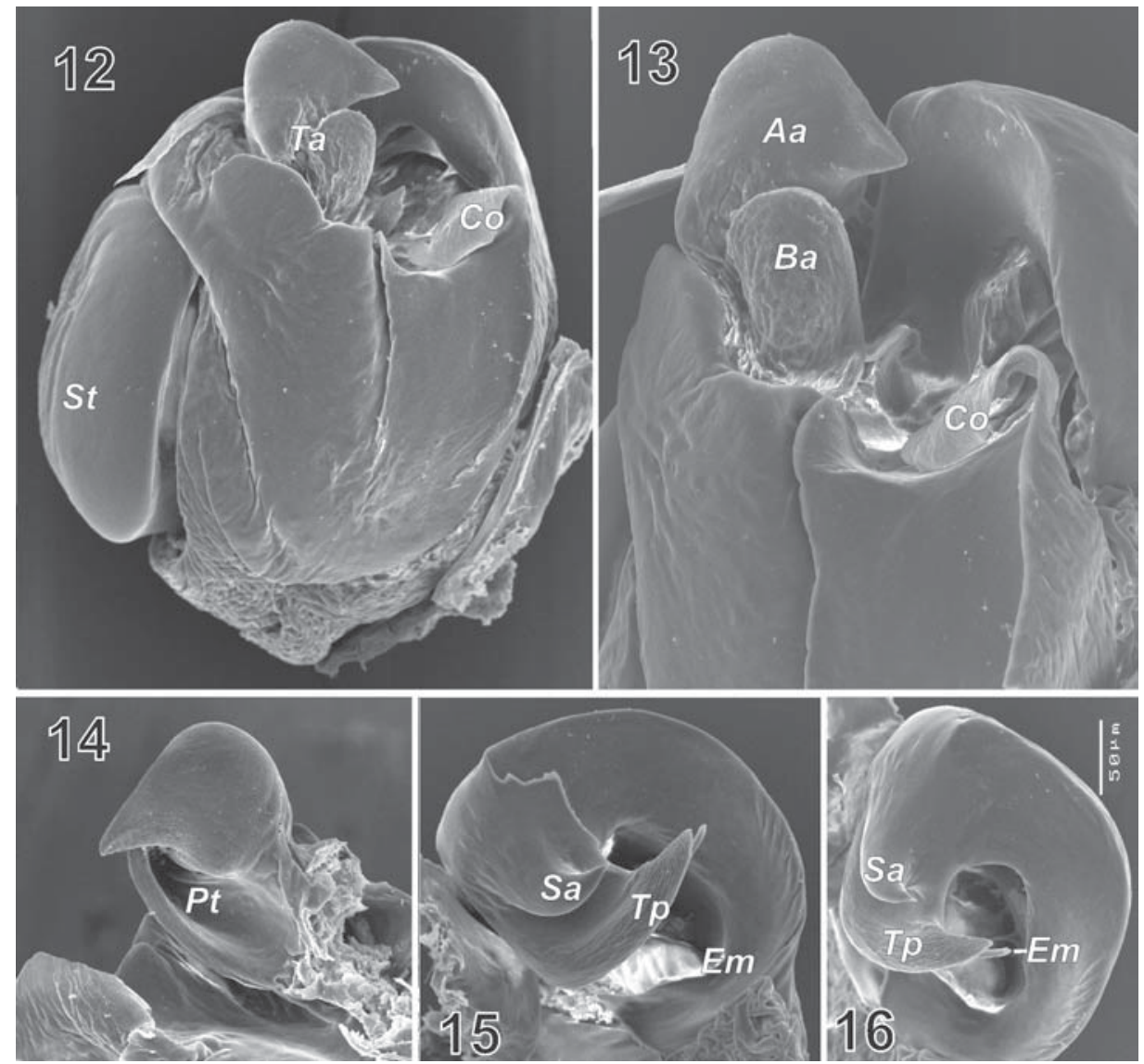

Figs 12-16. Bulbus of Pirata piraticus: 12 - ventral view; 13 - tegular apophysis, retrolateral view, 14 - dorsal view; 15,16 terminal apophysis.

Рис. 12-16. Бульбус Pirata piraticus: 12 — вентрально; 13 - тегулярный отросток, ретролатерально, 14 — дорсально; 15,16 терминальный апофиз.

Eyes. Roewer [1960] considered the eye arrangement as the most important character in distinguishing lycosid genera. Piratula was distinguished from Pirata based on its eyes. One of the characters in the eye formula was a straight or procurved first eye row. The generotypes of both Pirata and Piratula have a straight first eye row, whereas in other species from both genera the eye row may be procurved (cf. Figs 1-2). The relative length of the first and second eye rows is also variable within both genera and so cannot be used as a diagnostic character for distinguishing between them.

Sternum. All the Far Eastern Piratula species have a more or less developed pattern comprised of a light median band or stripe and 3 pairs of sublateral light round spots (Figs 4-5) similar to that observed in Tegenaria (Agelenidae). In Pirata the sternum is uniformly coloured (Figs 3a,b) or sometimes has dark lateral spots (Fig. 3d) or small submedian dots (Fig. 3c).

Legs. Spination in leg I can help in some cases to separate males of species within Pirata and Piratula (cf. Table 1). Spination of leg I in females permits discrimination between the two genera. All the Piratula species examined have one prolateral tibial spine, whereas this is absent in Pirata (cf. Table 2). Some species of Piratula can be distinguished based on the coloration of the legs. For example, $P$. yaginumai has distinct annulations (Fig. 140), whereas in most species the annulations are absent or indistinct. $P$. logunovi sp.n. and P. tanakai have a black femur I in males (Figs 83 and 126).

MALE PALP. There are several characters in the male palp that allow identification of species and genera.

Tibia. Piratula meridionalis has a curved palpal tibia (Fig. 92), whereas in other species it is straight. In Piratula borea the proximal part of the palpal tibia is thicker than the distal (Fig. 49). The spination of the retrolateral part of the male palp is also diagnostic of species in some cases.

Cymbium. The shape, proportions and colour of the cymbium are an aid to species identification in some cases. In several species the tip of the cymbium is conical, whereas in others it is rounded. The relative size (length) of the tip of the cymbium may help to discriminate species (cf. Figs 158-169). The length/ width ratio of the cymbium serves to separate some species. For example, in Piratula logunovi sp.n. it is 1.83 , while in $P$. canadensis the ratio is 1.57 . The upper part of the cymbium is short (cymbial tip height 


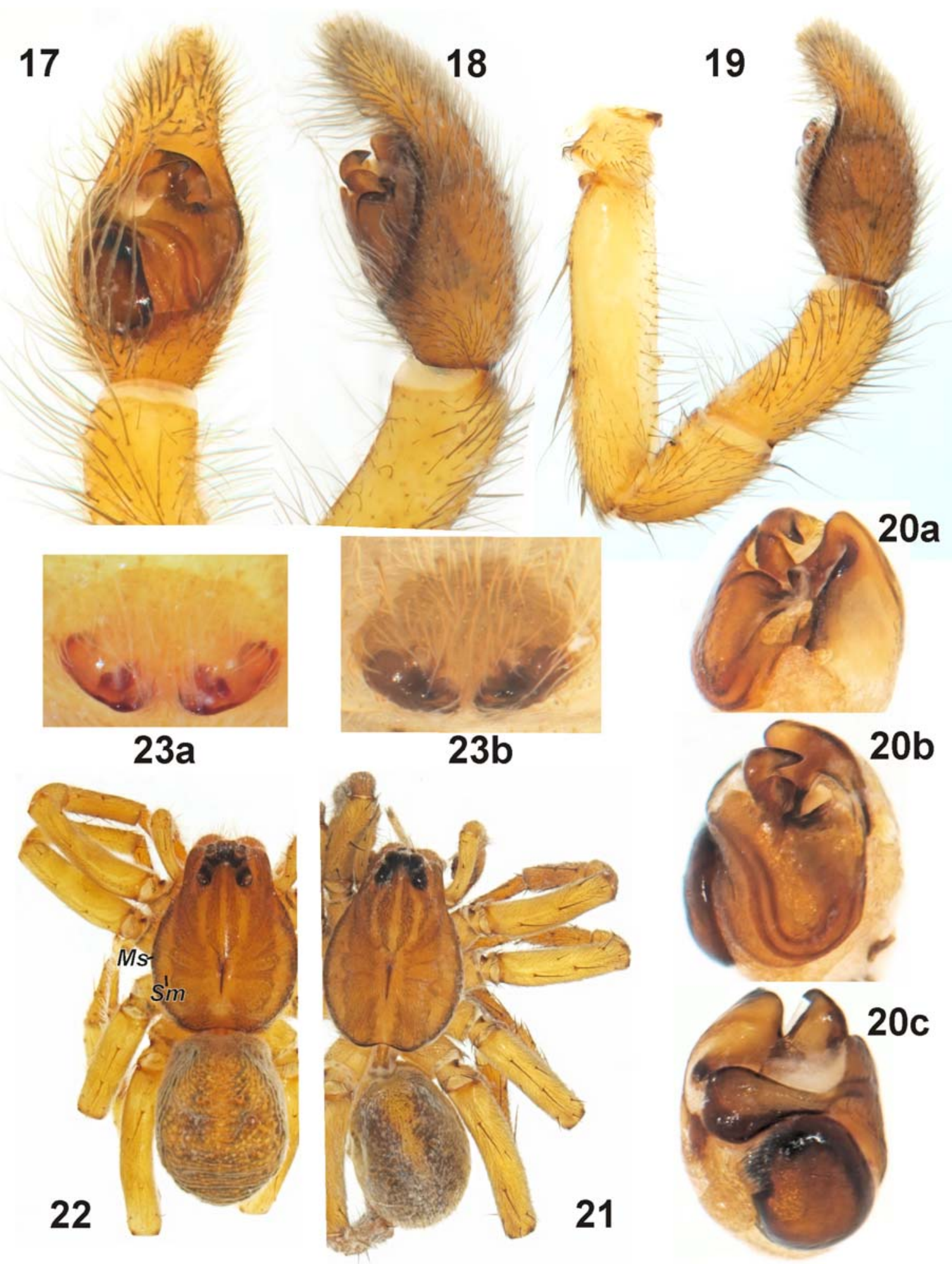

Figs 17-23. Pirata praedo: 17 - palp, ventral view, 18 - palp, retrolateral view; 19 - whole palp; 20a - bulbus, retrolateral view, $20 \mathrm{~b}$ - ventral view, $20 \mathrm{c}$ - view from behind; 21 - general appearance of male; 22 - general appearance of female; $23 \mathrm{a}-\mathrm{b}-$ epigyne, ventral view.

Рис. 17-23. Pirata praedo: 17 - пальпа, вентрально, 18 - пальпа, ретролатерально; 19 - пальпа целиком; 20а — бульбус, ретролатерально, 20b - вентрально, 20c - вид сзади; 21 - внешний вид самца; 22 - внешний вид самки; $23 \mathrm{a}-\mathrm{b}$ - эпигина, вентрально. 
Table 1. Chaetotaxy of Pirata and Piratula males Таблица 1. Хетотаксия Pirata and Piratula males

\begin{tabular}{|c|c|c|c|c|c|}
\hline \multirow{2}{*}{ № } & \multirow{2}{*}{ Species } & \multicolumn{4}{|c|}{ Segment of leg I } \\
\hline & & Femur & Patella & Tibia & Metatarsus \\
\hline & Pirata & & & & \\
\hline 1. & P.piraticus & $3 \mathrm{~d} 1 \mathrm{p} 1 \mathrm{r}$ & $1 \mathrm{p}$ & $2 \mathrm{p} 2 \mathrm{r}(1 \mathrm{r}) 2-2 \mathrm{v}$ & $2 \mathrm{p} 2 \mathrm{r} 2-2 \mathrm{v}$ \\
\hline 2. & P.praedo & $3 d 1 p(2 p) 1 r$ & $1 \mathrm{p} 1 \mathrm{1r}(0 \mathrm{r})$ & $2 \mathrm{p} 2 \mathrm{r} 2-2 \mathrm{v}$ & $2 \mathrm{p} 1 \mathrm{r} 2-2 \mathrm{v}$ \\
\hline 3. & P. subpiraticus & $3 d 1 p(2 p) 2 r$ & $1 p$ & $2 p \operatorname{lr} 2-2 v$ & $1 \mathrm{p} 1 \mathrm{r} 2-2 \mathrm{v}$ \\
\hline & Piratula & & & & \\
\hline 4. & P. borea & $3 \mathrm{~d} 1 \mathrm{p} 1 \mathrm{r}$ & $1 p(0 p) 1 r(0 r)$ & $2 \mathrm{p} 2 \mathrm{r} 2-2 \mathrm{v}$ & $1 \mathrm{p} 1 \mathrm{r} 2-2 \mathrm{v}$ \\
\hline 5. & P. canadensis & $3 d 1 p$ & - & $2 p(1 p) 2-2 v$ & $1 \mathrm{p} 2-2 \mathrm{v}$ \\
\hline 6. & P. hygrophila & $3 \mathrm{~d} 1 \mathrm{p}$ & - & $1 \mathrm{p} 1 \mathrm{r} 2-2 \mathrm{v}$ & $2-2 v$ \\
\hline 7. & P. insularis & $3 \mathrm{~d} 1 \mathrm{p}$ & - & $2 \mathrm{p} 2-2 \mathrm{v}$ & $1 \mathrm{p} 2-2 \mathrm{v}$ \\
\hline 8. & P. logunovi sp.n. & $3 \mathrm{~d} \mathrm{1p}$ & - & $1 \mathrm{p} 1 \mathrm{r} 2-2 \mathrm{v}$ & $2-2 v$ \\
\hline 9. & P. meridionalis & $3 \mathrm{~d} 1 \mathrm{p} 1 \mathrm{r}$ & $1 \mathrm{p} 1 \mathrm{r}$ & $2 \mathrm{p} 2$ r $2-2 \mathrm{v}$ & $2 \mathrm{p} 1 \mathrm{r}(0 \mathrm{r}) 2-2 \mathrm{v}$ \\
\hline 10. & P. piratoides & $3 \mathrm{~d} \mathrm{1p} \mathrm{1r}$ & $1 \mathrm{p}$ & $2 \mathrm{p} 1 \mathrm{r} 2-2 \mathrm{v}$ & $1 \mathrm{p} 1 \mathrm{r} 2-2 \mathrm{v}$ \\
\hline 11. & P. serrulata & $3 \mathrm{~d} 1 \mathrm{p} 1 \mathrm{r}$ & $1 \mathrm{p}$ & $2 \mathrm{p} 1 \mathrm{r} 2-2 \mathrm{v}$ & $1 \mathrm{p} 1 \mathrm{r}(0 \mathrm{r}) 2-2 \mathrm{v}$ \\
\hline 12. & P. tanakai & $3 d 1 p$ & - & $1 \mathrm{p} 2-2 \mathrm{v}$ & $2-2 v$ \\
\hline 13. & P. yaginumai & $3 \mathrm{~d} 1 \mathrm{p} 1 \mathrm{r}$ & $1 p$ & $2 \mathrm{p} 1 \mathrm{r} 2-2 \mathrm{v}$ & $1 \mathrm{p} 2-2 \mathrm{v}$ \\
\hline
\end{tabular}

Table 2. Chaetotaxy of Pirata and Piratula females Таблица 2. Хетотаксия Pirata and Piratula females

\begin{tabular}{|c|c|c|c|c|c|}
\hline \multirow{2}{*}{ № } & \multirow{2}{*}{ Species } & \multicolumn{4}{|c|}{ Segment of leg I } \\
\hline & & Femur & Patella & Tibia & Metatarsus \\
\hline & Pirata & & & & \\
\hline 1. & P. piraticus & $3 d \operatorname{lp} 1 r(0 r)$ & - & $2-2 v$ & $2-2 v$ \\
\hline 2. & P. praedo & $3 d 1 p$ & - & $2-2 v$ & $2-2 v$ \\
\hline 3. & P. subpiraticus & $3 \mathrm{~d} 1 \mathrm{p} 2 \mathrm{r}$ & $1 \mathrm{p}$ & $2-2 v$ & $2-2 v$ \\
\hline \multirow[t]{2}{*}{4.} & P. tenuitarsis & $3 d 1 p$ & - & $2-2 v$ & $2-2 v$ \\
\hline & Piratula & & & & \\
\hline 5. & P. borea & $3 d \operatorname{lp} 1 r(0 r)$ & - & $1 \mathrm{p} 2-2 \mathrm{v}$ & $2-2 v$ \\
\hline 6. & P. canadensis & $3 d 1 p$ & - & $1 \mathrm{p} 2-2 \mathrm{v}$ & $2-2 v$ \\
\hline 7. & P. hygrophila & $3 d 1 p$ & - & $1 \mathrm{p} 2-2 \mathrm{v}$ & $2-2 \mathrm{v}$ \\
\hline 8. & P. insularis & $3 d 1 p$ & - & $1 \mathrm{p} 2-2 \mathrm{v}$ & $2-2 v$ \\
\hline 9. & P. logunovi sp.n. & $3 d 1 p$ & - & $1 \mathrm{p} 2-2 \mathrm{v}$ & $2-2 v$ \\
\hline 10. & P. meridionalis & $3 \mathrm{~d} 1 \mathrm{p} 1 \mathrm{r}$ & - & $1 \mathrm{p} 2-2 \mathrm{v}$ & $2-2 v$ \\
\hline 11. & P. piratoides & $3 \mathrm{~d} \mathrm{1p} \mathrm{1r}$ & - & $1 \mathrm{p} 2-2 \mathrm{v}$ & $2-2 v$ \\
\hline 12. & P. serrulata & $3 d 1 p$ & - & $1 \mathrm{p} 2-2 \mathrm{v}$ & $2-2 v$ \\
\hline 13. & P. yaginumai & $3 \mathrm{~d} 1 \mathrm{p} 1 \mathrm{r}$ & - & $1 \mathrm{p} 2-2 \mathrm{v}$ & $2-2 v$ \\
\hline
\end{tabular}

$<$ median apophysis height; Figs 158, 162-163) in several species and long in others (Figs 159, 169).

Bulbus proportions. The height/width ratio permits the separation of some species. For example, the type species of Piratula (P. hygrophila) has an almost round bulbus.

Subtegulum. The position and relative size of the subtegulum can be used to discriminate between all Far Eastern Pirata and Piratula. The subtegulum in Pirata is large ( $1 / 2$ of the bulbus height, Figs 167-169) and located prolaterally, whereas in Piratula it is short $(<1 / 2$ of the bulbus height) and located more centrally (Figs 158-162, 164-166). In Piratula hygrophila the subtegulum is small, but located on the prolateral side.
Seminal duct course. All Far Eastern Piratula have a subhorizontal seminal duct (Figs 158-162, 164-166), while in Pirata species it is more diagonal (cf. Figs 158-169). In Piratula hygrophila the seminal duct forms a strong loop.

Tegular apophysis. The shape of the tegular apophysis contains many characters that permit discrimination between species and genera. These characters are: proportions; indentation; size, number and position of denticles, relative size to subtegulum, etc.

Embolic division. The terminal apophysis shape and length allow species discrimination in some cases. The subterminal apophysis is a good distinguishable character for most of the Pirata and Piratula 

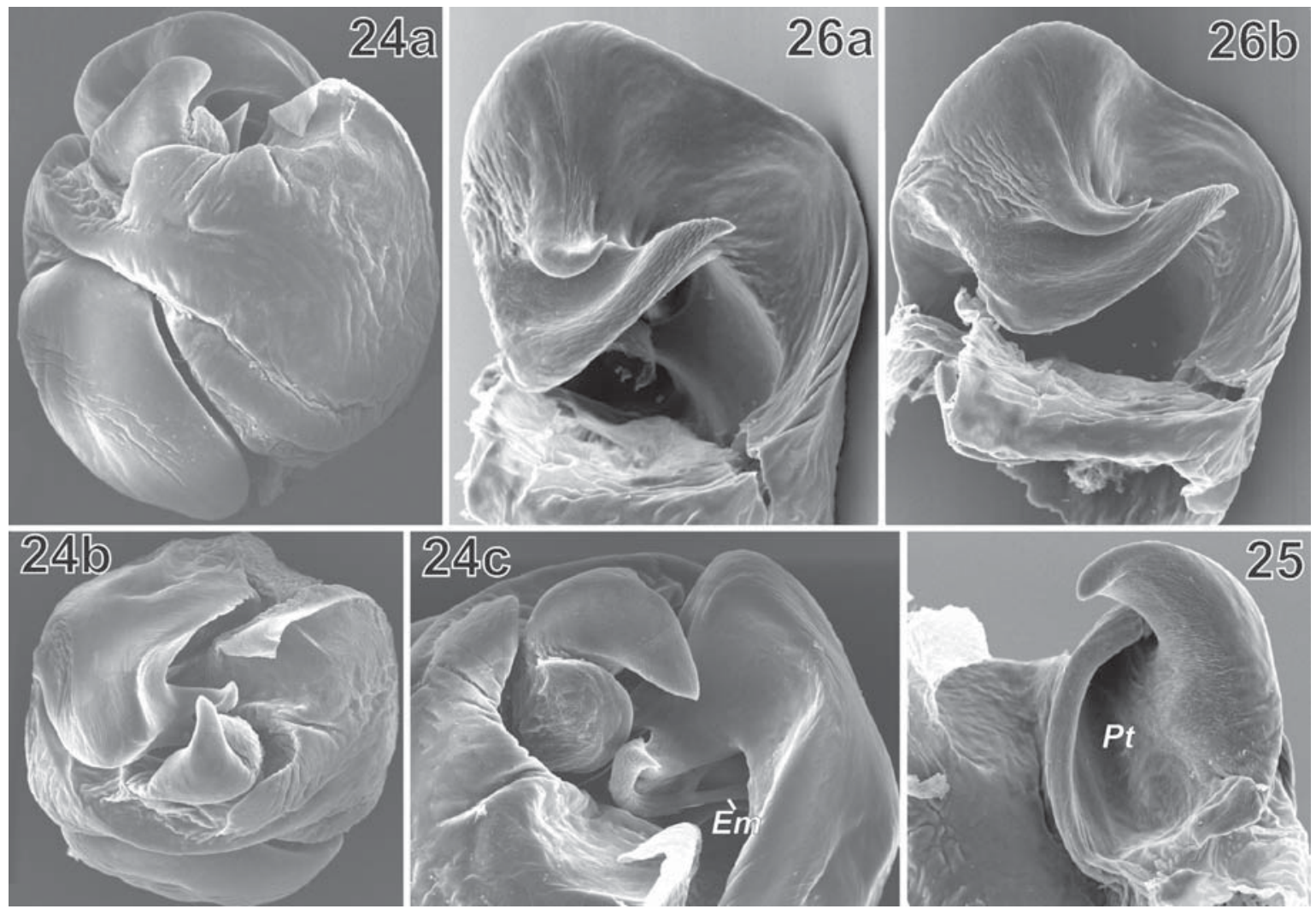

Figs 24-25. Bulbus of Pirata praedo: $24 \mathrm{a}$ - ventral view; $24 \mathrm{~b}$ - terminal part, view from above; $24 \mathrm{c}$ - retrolateral view; $25-$ tegular apophysis, dorsal view; 26a-b - terminal apophysis.

Рис. 24-25. Бульбус Pirata praedo: 24a - вентрально; 24b - терминальная часть, вид сверху; 24c — ретролатерально; 25 тегулярный отросток, дорсально; 26a-b - терминальный апофиз.

species. In Pirata this apophysis is well developed and sharply pointed (except in P. subpiraticus which has a rounded tip), while in Piratula it is small, sometimes ridge or knob-like and not sharply pointed (except in $P$. meridionalis).

EPIGYNE. Unlike other lycosids, the shape of the epigyne is not useful for separating species with certainty. Only in some species of Piratula does it have a characteristic shape. Although species discrimination is rather difficult, the two genera can be separated due to the relative size of the "lateral" receptacula and the "median" (or inner) receptacula. In Pirata they are subequal in length, and the diameter of the "lateral" receptacula is larger than that of the "median" receptacula, whereas in Piratula the "median" receptacula are longer, and often have a greater diameter than the "lateral" receptacula (Figs 146-157).

\section{Pirata Sundevall, 1833}

Type species: Araneus piraticus Clerck, 1757 from Sweden.

Two genera are currently considered as junior synonyms of Pirata: Sosilaus Simon, 1898 (type S. spini- ger Simon, 1898 from USA) and Piratula Roewer, 1960 (type Pirata hygrophila Thorell, 1872 from Sweden). Here we present evidence that Piratula should be re-validated.

DIAGNOSIS. Members of this genus can be distinguished from most other Holarctic lycosid genera by having two dark longitudinal stripes on a median light band on the carapace and by the large subtegulum in the male palp. Only three other genera: Piratula, Trochosa C.L. Koch, 1847 and Trebacosa Dondale \& Redner, 1981 have longitudinal stripes (Figs 9-10, 2021, 50-51, etc). In Trochosa these stripes are parallel, and in Pirata, Piratula and Trebacosa they converge and merge into one another near the fovea. Pirata can be distinguished from Trebacosa by having a larger subtegulum and smaller tegular apophysis. Males of Pirata can be distinguished from those of Piratula by having a large prolateral subtegulum with its height greater than $1 / 2$ of the tegulum height (less than $1 / 2$ in Piratula, cf. Figs 158-169) and a small tegular apophysis, smaller in height than the subtegulum (tegular apophysis higher or subequal to height of subtegulum in Piratula). Females of Pirata can be easily recognized by having no prolateral tibial spine on leg I (one spine in Piratula). Pirata have a light uniformly co- 


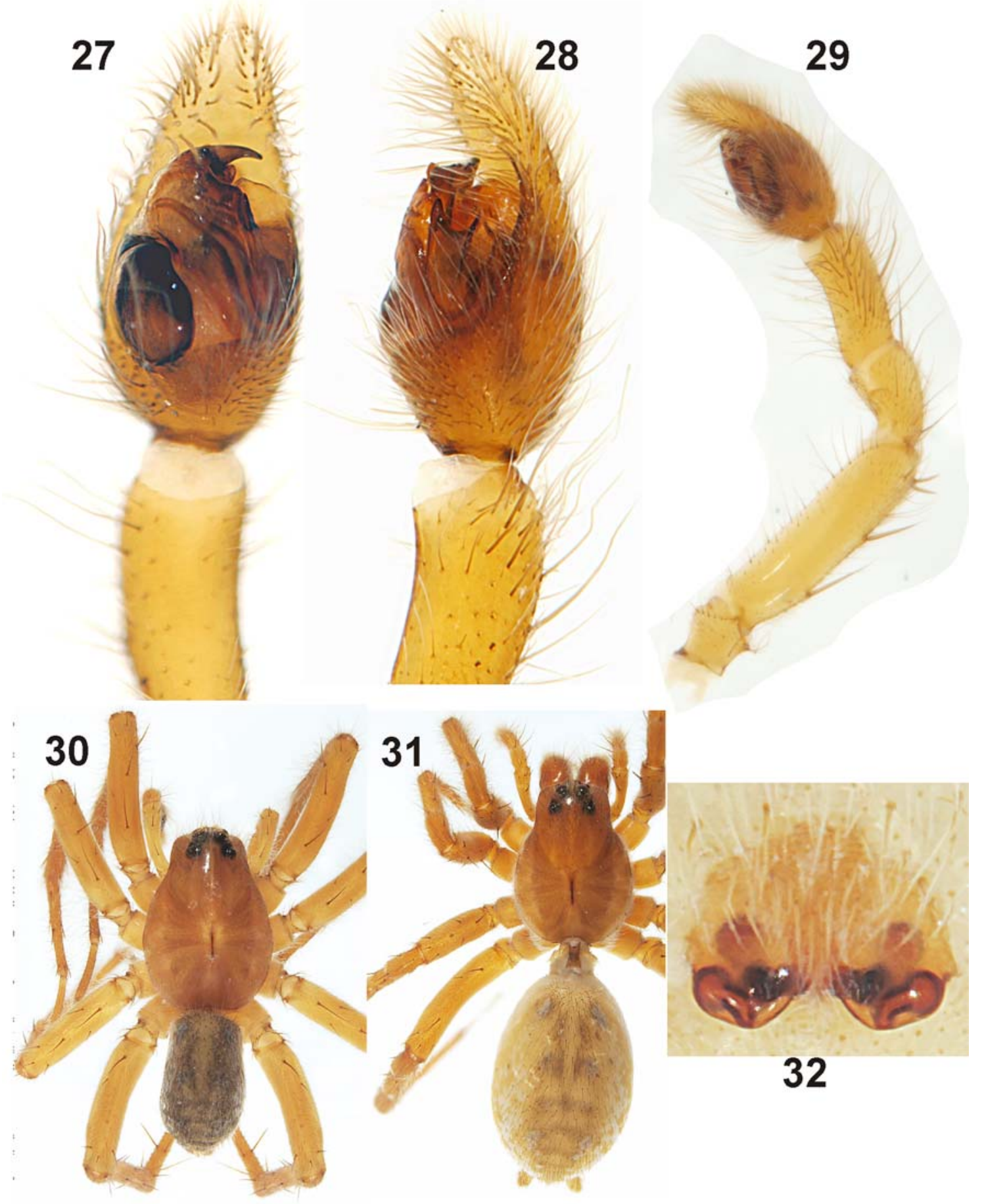

Figs 27-32. Pirata subpiraticus: 27 - palp, ventral view, 28 - palp, retrolateral view; 29 - whole palp; 30 - general appearance of male; 31 - general appearance of female; 32 - epigyne, ventral view.

Рис. 27-32. Pirata subpiraticus: 27 - пальпа, вентрально, 28 - пальпа, ретролатерально; 29 - пальпа, целиком; $30-$ внешний вид самца; 31 - внешний вид самки; 32 - эпигина, вентрально.

loured sternum which lacks any light spots (Piratula has 3 pairs of light sublateral spots). In addition, males of Pirata have no teeth on the upper arm of the tegular apophysis and the lateral arm is not pointed. In most
Piratula the upper arm of the tegular apophysis has one or even two teeth, and the lateral arm of the tegular apophysis is pointed. The two genera can also be differentiated by size (cf. Figs 178-179): most 우 of 

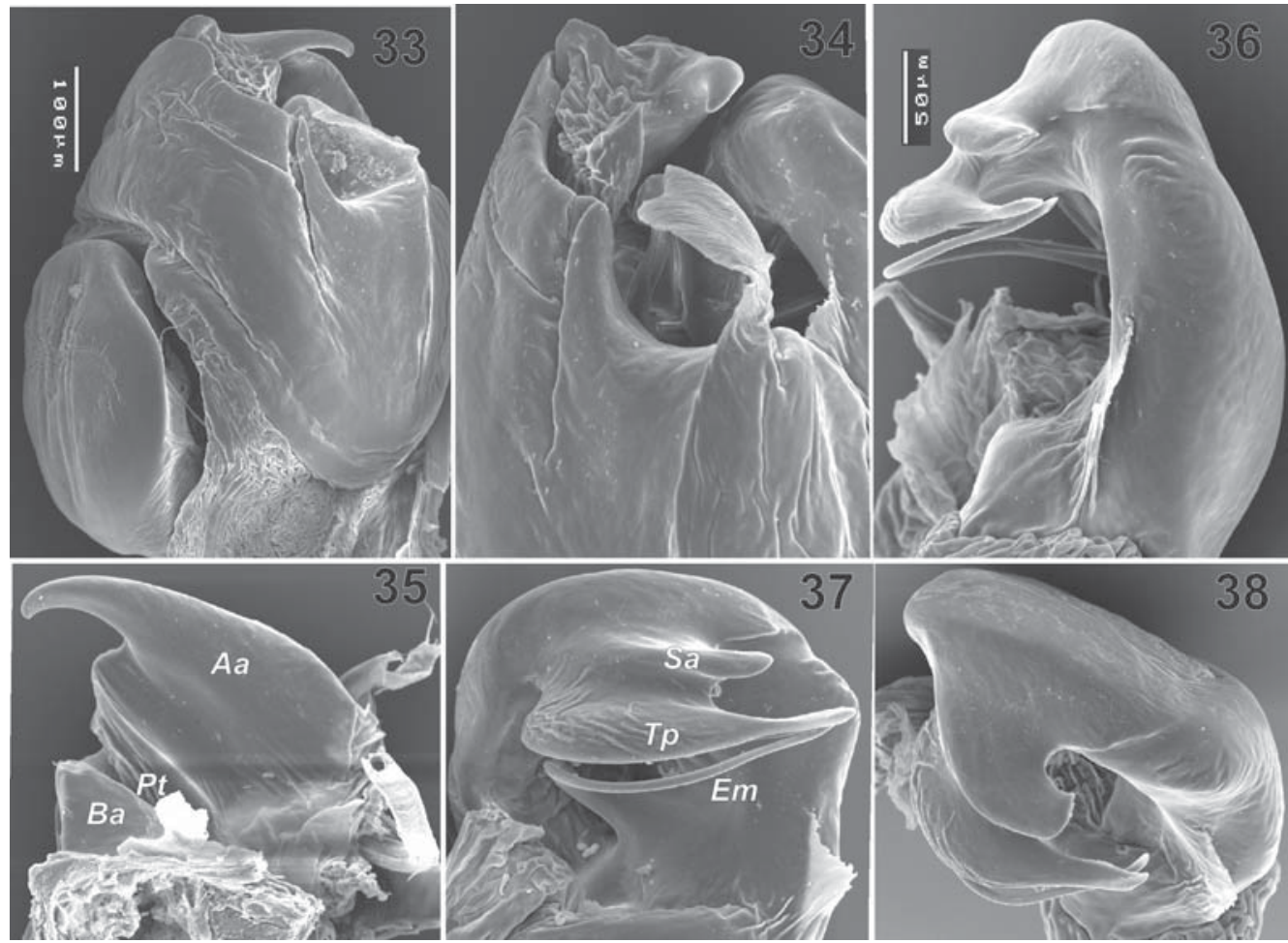

Figs 33-38. Bulbus of Pirata praedo: 33 - ventral view; 34 - terminal part, retrolateral view; 35 - tegular apophysis, dorsal view; 36 - terminal apophysis and embolus; 37 - terminal part, view from above; 38 - terminal apophysis.

Рис. 33-38. Бульбус Pirata praedo: 33 - вентрально; 34 - терминальная часть, ретролатерально; 35 - тегулярный отросток, дорсально; 36 - терминальный апофиз и эмболюс; 37 - терминальная часть, вид сверху; 38 - терминальный апофиз.

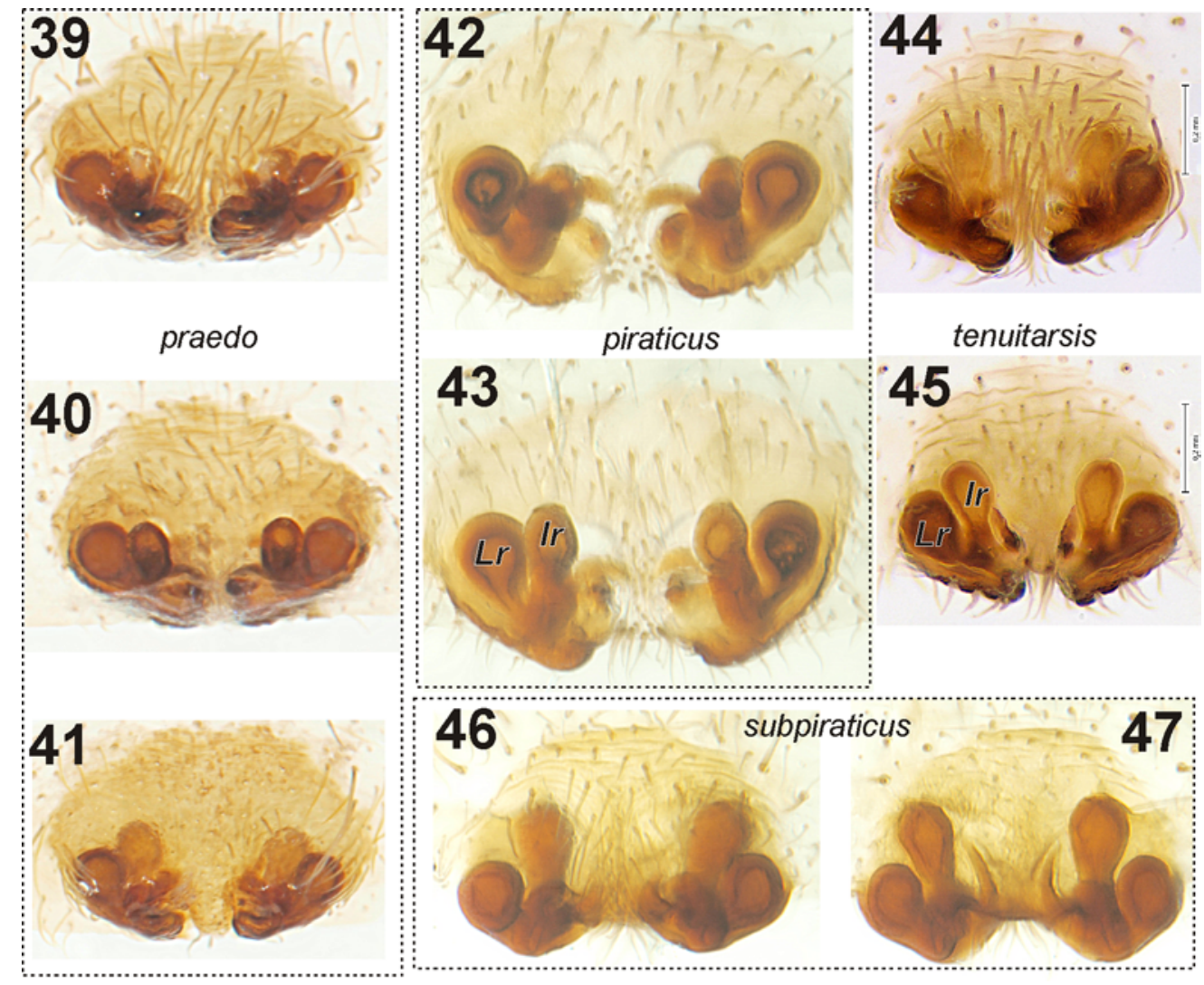

Figs 39-47. Epigynes of Pirata praedo (39-41), P. piraticus (42-43), P. tenuitarsis (44-45), and P. subpiraticus (46-47). Pис. 39-47. Эпигины Pirata praedo (39-41), P. piraticus (42-43), P. tenuitarsis (44-45), and P. subpiraticus (46-47). 


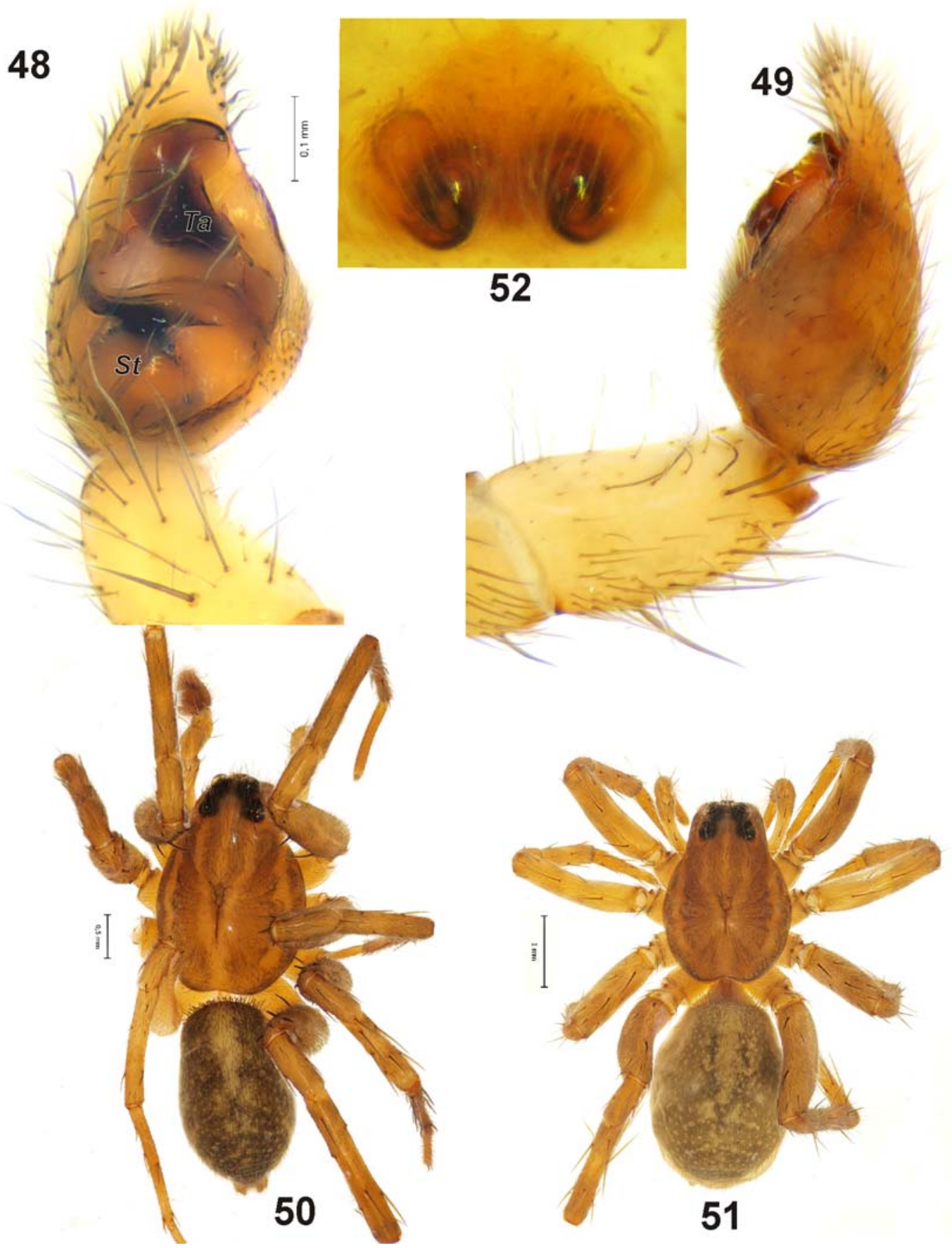

Figs 48-52. Piratula borea: 48 - palp, ventral view, 49 - palp, retrolateral view; 50 - general appearance of male; 51 - general appearance of female; 52 - epigyne, ventral view.

Рис. 48-52. Piratula borea: 48 - пальпа, вентрально, 49 - пальпа, ретролатерально; 50 - внешний вид самца; 51 — внешний вид самки; 52 - эпигина, вентрально.

Pirata (carapace $2.75 \mathrm{~mm}$ and longer) are larger than those of Piratula (less than $3 \mathrm{~mm}$ ).

Misplaced species. Most Pirata species described from outside of the Holarctic and adjacent territories seem to be misplaced. Examination of the figures of the epigynes of two African species assigned to Pirata revealed that they actually belong to Trochosa: Trochosa fabella (Karsch, 1879), comb.n., Trochosa mossambicus (Roewer, 1960), comb.n., both ex Pirata. These species are known only from females and have an anchor-like epigynal septum and parallel stripes on the median bands of the carapace as in the type species of the genus Trochosa (cf. Roewer, 1960: f. 479a-b \& f. 480a-b). Females of Pirata have no epigynal septum. 

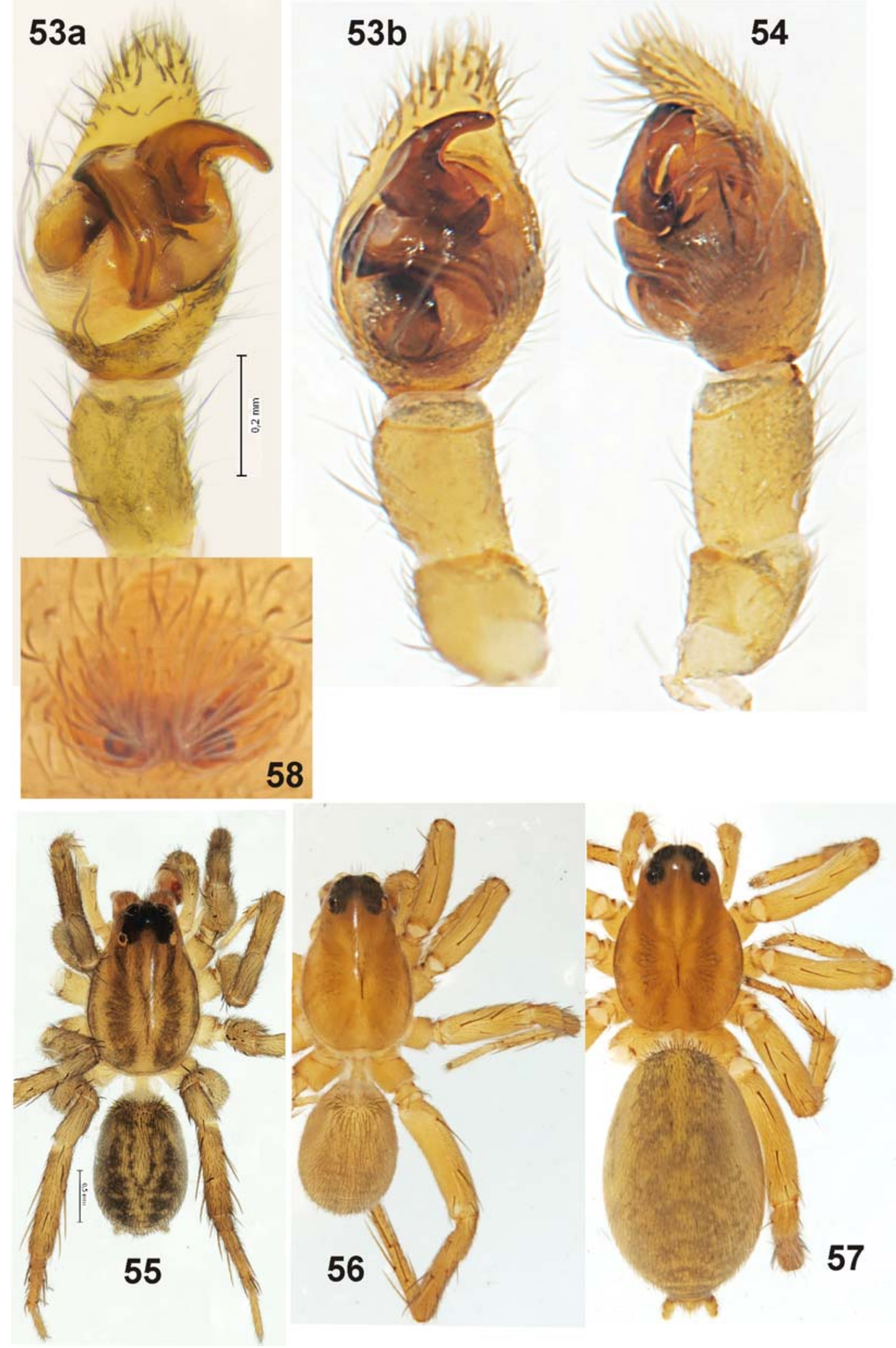

Figs 53-57. Piratula canadensis: 53a - palp, ventral view (male from Kamchatka), 53b - palp, ventral view (male from Bolshekhekhtsyrski State Reservation),54 - retrolateral view; 55 - general appearance of male from Kamchatka; 56 - general appearance of male from Bolshekhekhtsyrski State Reservation; 57 - general appearance of female; 58 - epigyne.

Рис. 53-57. Piratula canadensis: 53a - пальпа, вентрально (самец из Камчатки), 53b - пальпа, вентрально (самец из Большехехцирского заповедника), 54 - ретролатерально; 55 - внешний вид самца из Камчатки; 56 - внешний вид самца из Большехехцирского заповедника; 57 - внешний вид самки; 58 - эпигина. 

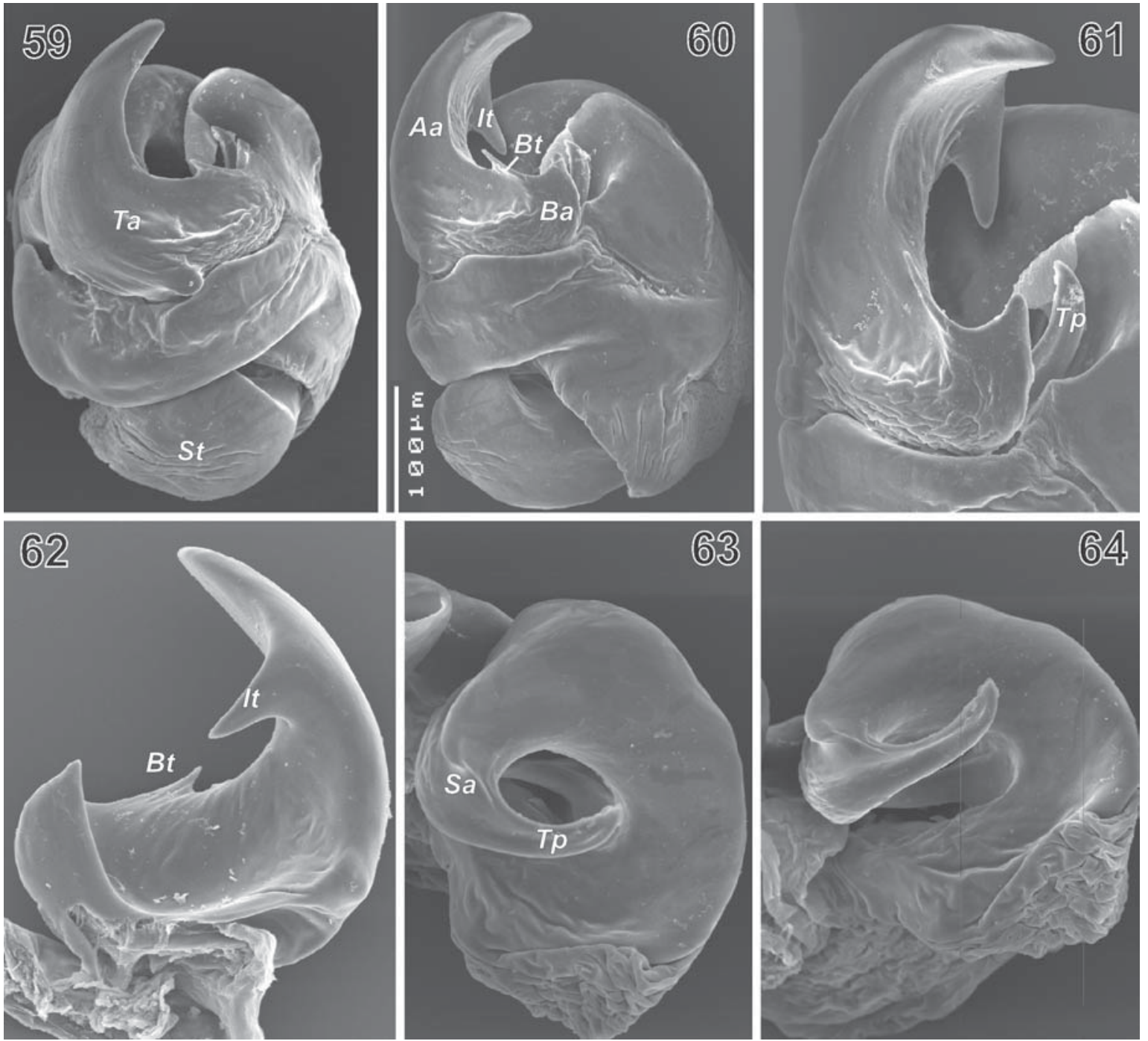

Figs 59-64. Bulbus of Piratula canadensis: 59 - ventral view, 60 - retrolateral view; 61 - tegular apophysis, retrolateral view, 62 - dorsal view; 63, 64 - terminal apophysis.

Рис. 59-64. Бульбус Piratula canadensis: 59 - вентрально, 60 - ретролатерально; 61 - тегулярный отросток, ретролатерально, 62 - дорсально; 63, 64 - терминальный апофиз.

COMPOSITION. The majority of species currently included in Pirata actually belong to Piratula (see below). Here we survey the species that undoubtedly belong to Pirata: Pirata piraticus (Clerck, 1757), $P$. piscatorius (Clerck, 1757), P. praedo Kulczyński, 1885, $P$. subpiraticus (Bösenberg \& Strand, 1906) and $P$. tenuitarsis Simon, 1876.

It is impossible to resolve the assignment of most of the Nearctic Pirata species, as only few of them (viz. Canadian species) have been properly illustrated (cf. Dondale \& Redner, 1990).

It is worth mentioning that the genus Sosilaus Simon, 1898 (type $S$. spiniger Simon, 1898 from USA) which was synonymized with Pirata has distinctly different copulatory organs. It has a small subtegulum, subhorizontal seminal duct and a differently shaped tegular apophysis. Moreover, S. spiniger clearly differs from both Pirata and Piratula in having more spines on leg I: 6 pairs of lateral spines [cf. Chamberlin, 1908; Wallace \& Exline, 1978]. Pirata aspirans Chamberlin, 1904 is very similar to $P$. spiniger and may be conspecific with it. It is very likely that the genus Sosilaus should also be revalidated, but this requires further study.

Pirata piraticus (Clerck, 1757)

Figs 1a, 3a, 6-16, 42-43, 167, 175, Maps 1-2.

P.p.: Holm, 1947: 10, f. 4c, pl. 1, f. 7-8, pl. 9, f. $4\left(\mathrm{O}^{7}+\right)_{\text {). }}$

P.p.: Kronestedt, 1980: 65, f. 2A, 3B, D, 4A, 6A-C, 7D-F, $8 \mathrm{E}-\mathrm{F}, 9 \mathrm{C}-\mathrm{D}\left(\mathrm{O}^{\top}+\mathrm{P}\right)$.

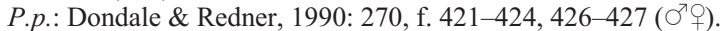

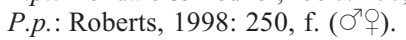



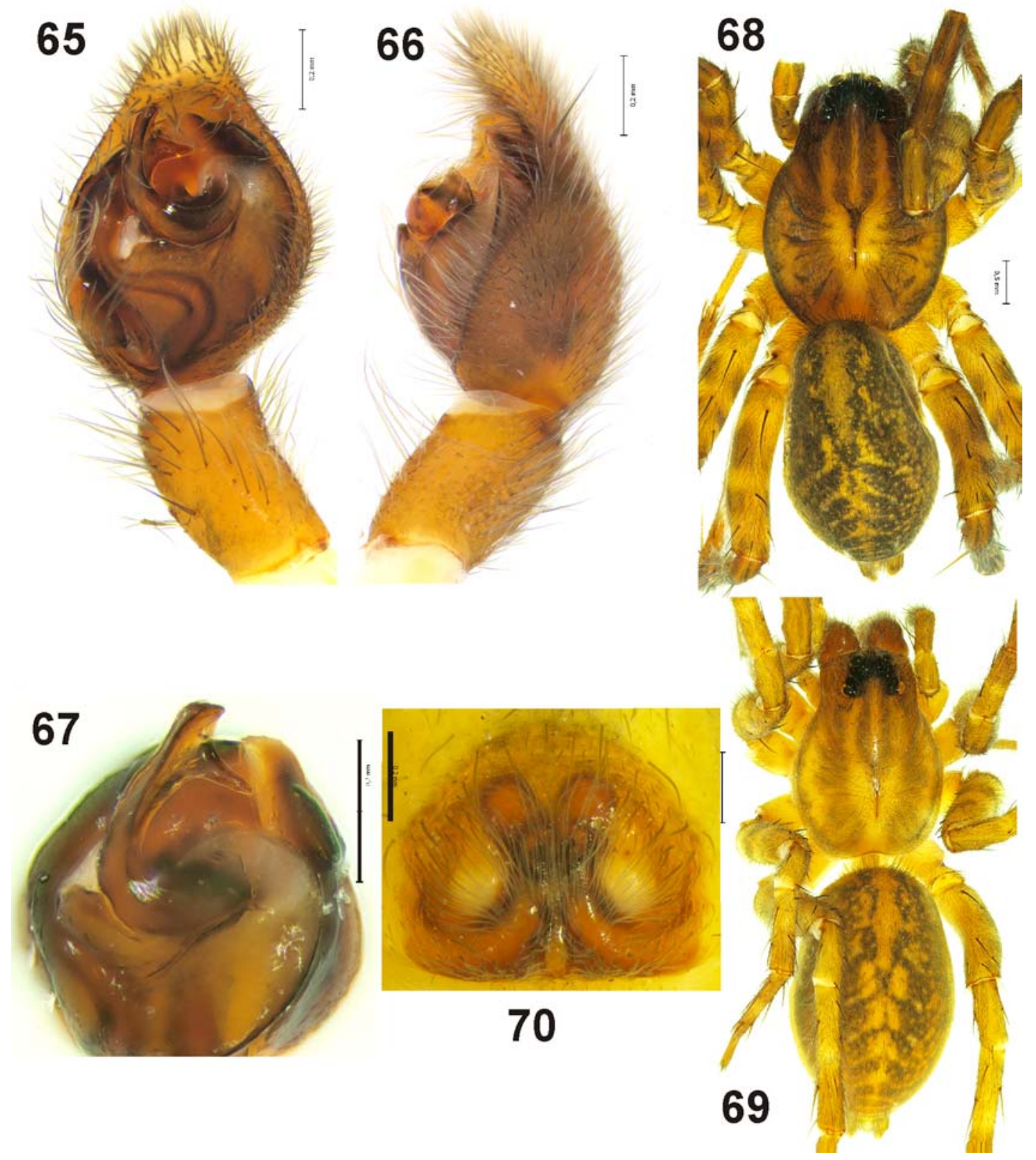

Figs 65-70. Piratula hygrophila: 65 - palp, ventral view, 66 - retrolateral view; 67 - bulbus, retrolateral view; 68 - general appearance of male; 69 - general appearance of female; 70 - epigyne, ventral view.

Рис. 65-70. Piratula hygrophila: 65 - пальпа, вентрально, 66 - ретролатерально; 67 - бульбус, ретролатерально; 68 внешний вид самца; 69 - внешний вид самки; 70 - эпигина, вентрально.

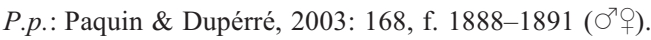
P.p.: Almquist, 2005: 243, f. 238a-f ( $\left(0^{7}+\right)$.

For more references see Platnick [2011].

MATERIAL EXAMINED. RUSSIA: Sakhalin Isl.: 9 o $^{7} 0^{7} 18$ of (ZMMU), SE part, environs of Starodubskoye Vil., Naiba River mouth part, $47^{\circ} 24.992^{\prime} \mathrm{N} 142^{\circ} 45.384^{\prime} \mathrm{E}, 23.07-12.08 .2001$ (Yu.Marusik); $1 \mathrm{O}^{7} 1$ ( (ZMMU), Aniva Distr., Mitsulyovka Vil., 11.06.1985 (A.M. Basarukin); $1 \sigma^{7}$ (ZMMU), Aniva Distr., environs of Lugovoye Vil., 20.06.1985 (A.M.Basarukin). Maritime Prov.: 1 क (ZMMU), Khanka Lake, CE shore, $44^{\circ} 39^{\prime} \mathrm{N} 132^{\circ} 34^{\prime} \mathrm{E}$, 15-16.07.1998 (Y.M. Marusik); $2 \bigcirc^{7} \sigma^{7} 4$ 우 (ZMMU), Nadezhdinskii Dist., De-Phriz Peninsula., 18-20.08.2004 (M.M. Omelko); O $0^{7}+0^{7}+(\mathrm{ZMMU})$, Khanka Lake CW shore, Sosnovy Isl. \& peninsula nearby, $44^{\circ} 52^{\prime} \mathrm{N} 132^{\circ} 07^{\prime} \mathrm{E}, 17.07 .1998$ (Y.M. Marusik); 1 $\sigma^{7} 2$ + 0 (GTS), Spasskii Dist, environs of Novoselskoe Vil., 1521.07.2005 (M.M. Omelko). Irkutsk Area: 2 우 (ZMMU), Dahabilskaya steppe on the left side of Dolinda river of left tributary of Chona River, bog in the steppe, 8-9.07.1926 (M. Tkachenko).

DIAGNOSIS. Among the Far Eastern species it is most similar to $P$. praedo. $P$. piraticus and $P$. praedo have a similar body size but differ from each other by the pattern on the carapace. P. piraticus has no marginal dark stripes whereas $P$. praedo has a dark and thin submarginal stripe. The two species have distinctly different copulatory organs. 


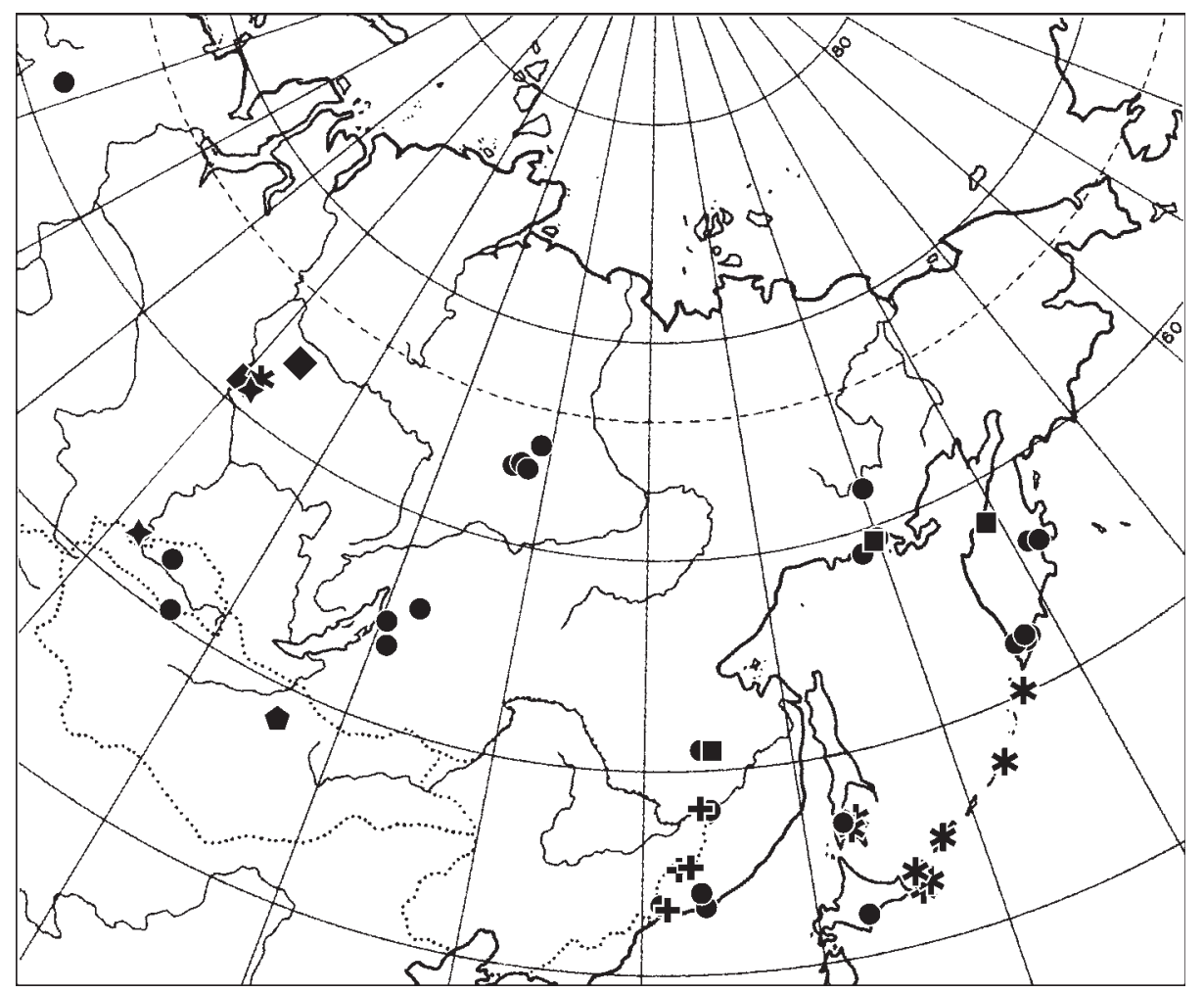

Map 1. Distribution of widespread species of Pirata and Piratula in Siberia and the Russian Far East.

Pirata piraticus $(\boldsymbol{*})$, P. praedo $(\mathbf{\bigcirc})$, P. tenuitarsis $(\bullet)$, Piratula canadensis $(\boldsymbol{\square})$, P. hygrophila $(\bullet)$, P. insularis $(\bullet)$ and P. serrulata $(\mathbf{+})$.

Карта 1. Распространение широкораспространённых видов Pirata and Piratula в Сибири и на Дальнем Востоке.

Pirata piraticus $(\boldsymbol{*})$, P. praedo $(\bullet)$, P. tenuitarsis $(\bullet)$, Piratula canadensis $(\square)$, P. hygrophila $(\downarrow)$, P. insularis $(\bullet)$ and P. serrulata $(\mathbf{+})$.

DESCRIPTION. The species was well described by Kronestedt [1980]. Carapace and abdomen with the typical pattern (Figs 9-10). Dark marginal stripes absent, wide yellow marginal bands. Sternum light yellow with three pairs of dark patches along the edges (Fig. 3a). Eye arrangement as in Fig. 1a. Median row of eyes wider than anterior. Abdomen brown with heart mark and several pairs of white spots almost unnoticeable in alcohol. Legs without annulations. Chaetotaxy of leg I as shown in Tables 1-2. Palp as in Figs 6-8, 12-16. Cymbial length/width ratio 1.83. Tegular apophysis hook-like with rounded basal arm. Tegular apophysis with distinct pocket. Terminal apophysis with well developed pointed subterminal apophysis. Epigyne and vulva as in Figs 11, 42-43.

COMMENTS. It is the type species of the genus.

BIOLOGICAL NOTES. This species occurs in moist habitats like lake shores, rivers banks, ponds and bogs. It is possible that $P$. piraticus may compete with $P$. praedo. These two species have the same size and phenology, and in the Maritime province only one of these occurs in any suitable habitat.

DISTRIBUTION. The species has a circumHolarctic range and occurs throughout all Eurasia and the Nearctic.
Pirata praedo Kulczyński, 1885

Figs 1b, 3b, 3c, 17-26b, 39-41, 169, 177, Maps 1, 2.

P.p.: Logunov, 1992: 60, f. 6 ( ${ }^{\top}+$ ) $)$.

P. shibatai Tanaka, 1995: 47, f. 1-4 (D ${ }^{7}+$ ).

P. zelotes Wallace \& Exline, 1978: 70, f. 13, 140-142, 145 $\left(\sigma^{7}+\right)$. Syn.n.

P. zelotes: Paquin \& Dupérré, 2003: 169, f. 1895-1898 ( $\sigma^{7}+$ ). P. shibatai: Tanaka, 2009: 225, f. 16-17 ( $\mathrm{O}^{\top}+$ ).

P.p.: Marusik et al., 2010: 33, f. 1-29 ( $\sigma^{r}$ ) $)$.

MATERIAL EXAMINED. RUSSIA: Tuva: $6 \sigma^{7} \sigma^{\top} 5$ 우 (ZMMU), Tere-Khol' Lake, Sharlaa Stand, 5001.47'N 9503.45'E, 1050 m, 614.07.1996 (Y.M. Marusik). Buryatia: $1 \sigma^{7}$ (ZMUT), Vitim River, Bargalino, bog, 5.08.1976 (E. Alekseeva); $2 \sigma^{7} \sigma^{\top} 1$ ㅇ (ZMMU),

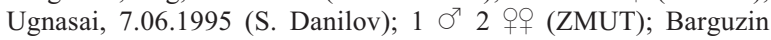

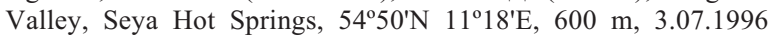
(M. Uusitalo); 3 우 (ISEA), Daurski Reserve, SW shore of BarunTorei Lake, Bulum-Khuduk campground, steppe and lake shore, 13-23.06.1995 (I. Lyubechanski). Khabarovsk Prov.: 2 o $\sigma^{7} 1$ 우 (ZMMU), Bureya River upper reaches, Umalta River, ox-bow in Chosenia forest, 2.06.2001 (L. Trilikauskas). Magadan Area: $5 \sigma^{7} \sigma^{7}$ 5 90 (IBPN), Kolyma River upper reaches, ca $62^{\circ} \mathrm{N}$, Aborigen Field Station, bog near Kolyma River, Summer 1983 (Y.M. Marusik); 3 $\sigma^{\top} \sigma^{7}$ (IBPN), Chelomdzha River, Field Station, Summer 1987 (N.E. Dokuchaev). Kamchatka Area: 1 + (ZMMU Ta-2455), Kamchatka River, $2.5 \mathrm{~km}$ downstream of Krasnaya Vil., 19.08.1930 (V.I. Sytchevskaya); 1 (ZMMU), near Khomnovoye Vil., Kamchatka River, on moist soil, 07.1930 (V.I. Sytchevskaya); 6 q0 (ZMMU Ta-2458), near Khomnovoye Vil., Kamchatka River, on 

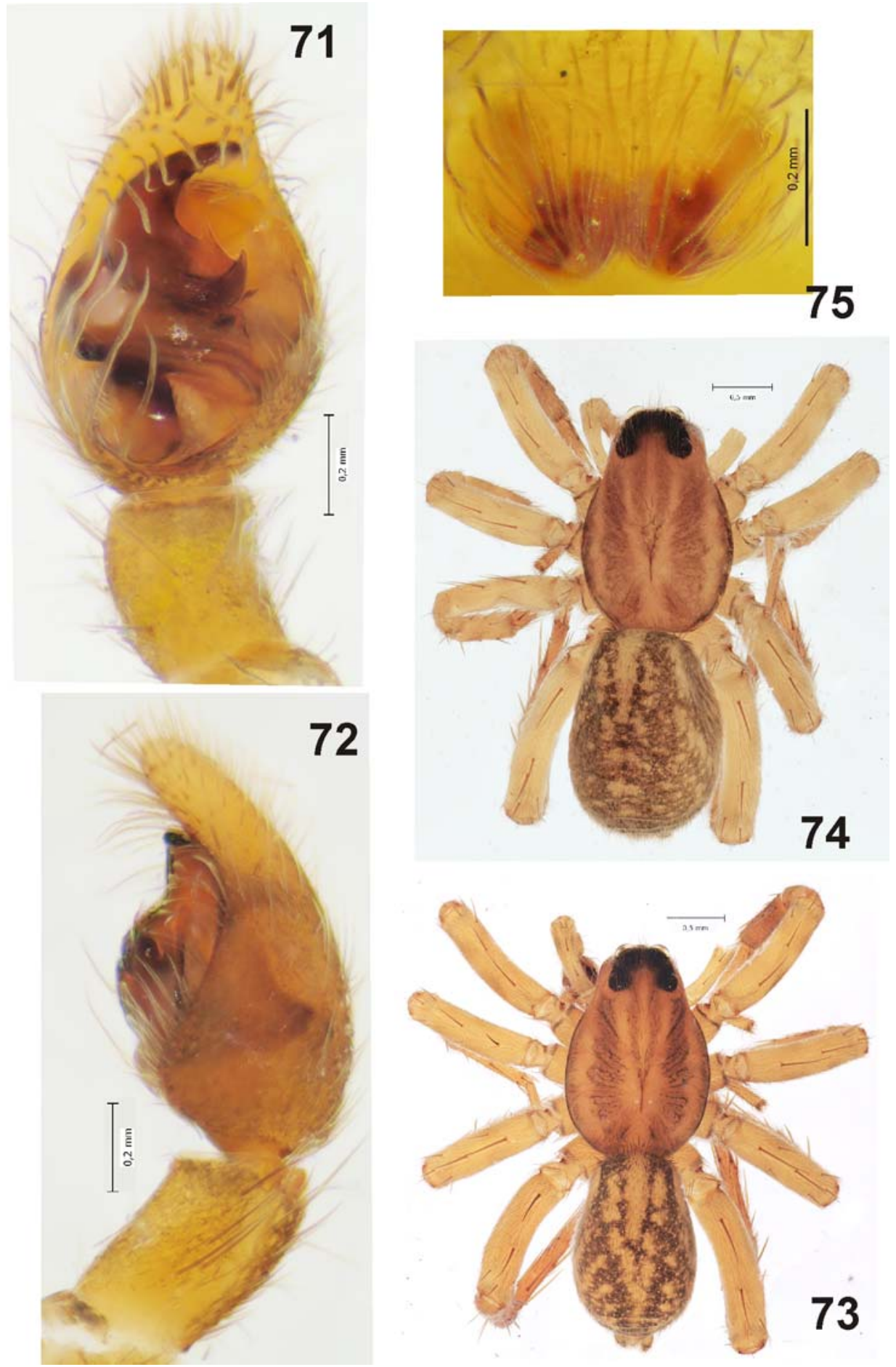

Figs 71-75. Piratula insularis: 71 - palp, ventral view, 72 - palp, retrolateral view; 73 - general appearance of male; 74 - general appearance of female; 75 - epigyne, ventral view.

Pис. 71-75. Piratula insularis: 71 - пальпа, вентрально, 72 - пальпа, ретролатерально; 73 - внешний вид самца; 74 внешний вид самки; 75 - эпигина, вентрально. 


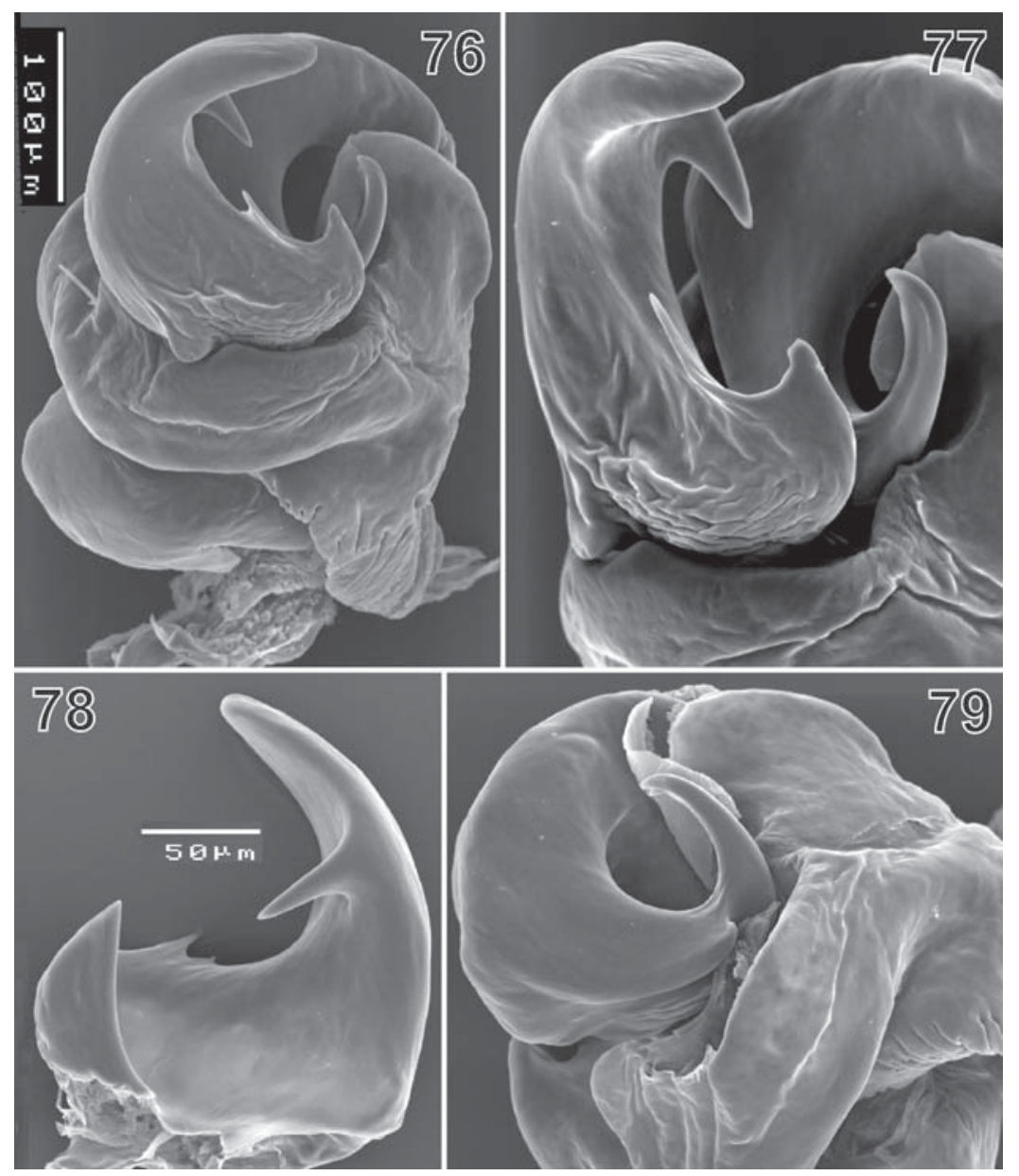

Figs 76-79. Bulbus of Piratula insularis: 76 — ventral view, 77 — tegular apophysis, retrolateral view, 78 — dorsal view; 79 terminal apophysis.

Рис. 76-79. Бульбус Piratula insularis: 76 — вентрально; 77 — тегулярный отросток, ретролатерально, 78 — дорсально; 79 терминальный апофиз.

moist soil, 16.08.1930 (V.I. Sytchevskaya); 194 juv. (ZMMU Ta2461), Kamchatka River, near Yelovka River, 30.08 .1930 (V.I. Sytchevskaya); $4 \sigma^{\top} \sigma^{\top} 2$ 우 (IBPN), 10-12 km N of Paratunka Vil., Yelizovo Forestry, $53.050^{\circ} \mathrm{N} 158.225^{\circ} \mathrm{E}, 15-28.07 .2004$ (A.S. Ryabukin). Maritime Prov.: $4 \sigma^{\top} \sigma^{\top} 2$ o+ (ZMMU), Lazo Reserve, Proselochnaya bay, 8-12.04.2006 (Y. Sundukov); $20^{7} \sigma^{7}$ 1 O (ZMMU), Lazo Dist., Chukhunenko Lake, 19-25.07.2005 (M.M. Omelko); $2 \sigma^{7} \sigma^{7} 3$ q0 (ZMMU), Khasanski Dist., Lotos Lake, 17-18.07.2004 (M.M. Omelko); 2 우 (GTS) Khasanski Dist., environs of Riazanovka Vil., bog, 25-30.06.2009 (M.M. Omelko); $11 \sigma^{7} \sigma^{7} 5$ 우 (GTS), Spasskii Dist., environs of Novoselskoe Vil., 15-21.07.2005 (M.M. Omelko); 30 ○ ○ 20 우 (GTS), Lazovskii Dist., Chukhunenko Lake, 10-25.07.2005 (M.M. Omelko). Sakhalin Area: $1 \sigma^{7}$ (IBPN), Sakhalin Isl., SE part of Sakhalin, environs of Starodubskoye Vil., Naiba River mouth part, $47^{\circ}$ $24.992^{\prime} \mathrm{N} 142^{\circ} 45.384^{\prime} \mathrm{E}, 23.07 .2001$ (Y.M. Marusik). JAPAN, Hokkaido, paratypes of $P$. shibatai: $1 \sigma^{\top} 2$ of (ZMMU), JAPAN, Toyokoro-cho, Ohtsu-shitchi, 27.06.1993 (K. Shibata).

USA, Michigan, holotype $\sigma^{7} \&$ allotype 9 of $P$. zelotes $(\mathrm{MCZ})$ : Livingston Co., E. S. George Reserve, Grid M-28, VII.15.1954 1789H (H.K. Wallace).

DIAGNOSIS. This species is similar to $P$. piraticus. For differences between these two related species, see the diagnosis of $P$. piraticus.
DESCRIPTION. This species was well described by Marusik et al. [2010]. Carapace and abdomen with typical pattern (Figs 21-22). Median band and submarginal stripes yellow. Marginal stripes and submedian bands dark. Sternum sometimes with dark spots. Eye arrangement as in Fig. 1b. Median row of eyes wider than anterior. Abdomen with heart mark, white spots absent. Legs without annulations. Chaetotaxy of leg I as shown in Tables 1-2. Palp as in figs 17-20c. Cymbial length/width ratio 1.96. Tegular apophysis small, as wide as as tall, apical arm very small, pocket of median apophysis well developed. Terminal apophysis with a long, pointed subterminal apophysis (Figs 26a,b). Epigyne and vulva as in Figs 23a, 23b, 39-41.

COMMENTS. Comparison of the holotype male of $P$. zelotes Wallace \& Exline, 1978 with males of $P$. praedo reveals no differences in the shape of the palp and therefore these two names are synonymized here.

BIOLOGICAL NOTES. This species occurs in moist habitats such as lake shores, rivers, ponds and bogs. 

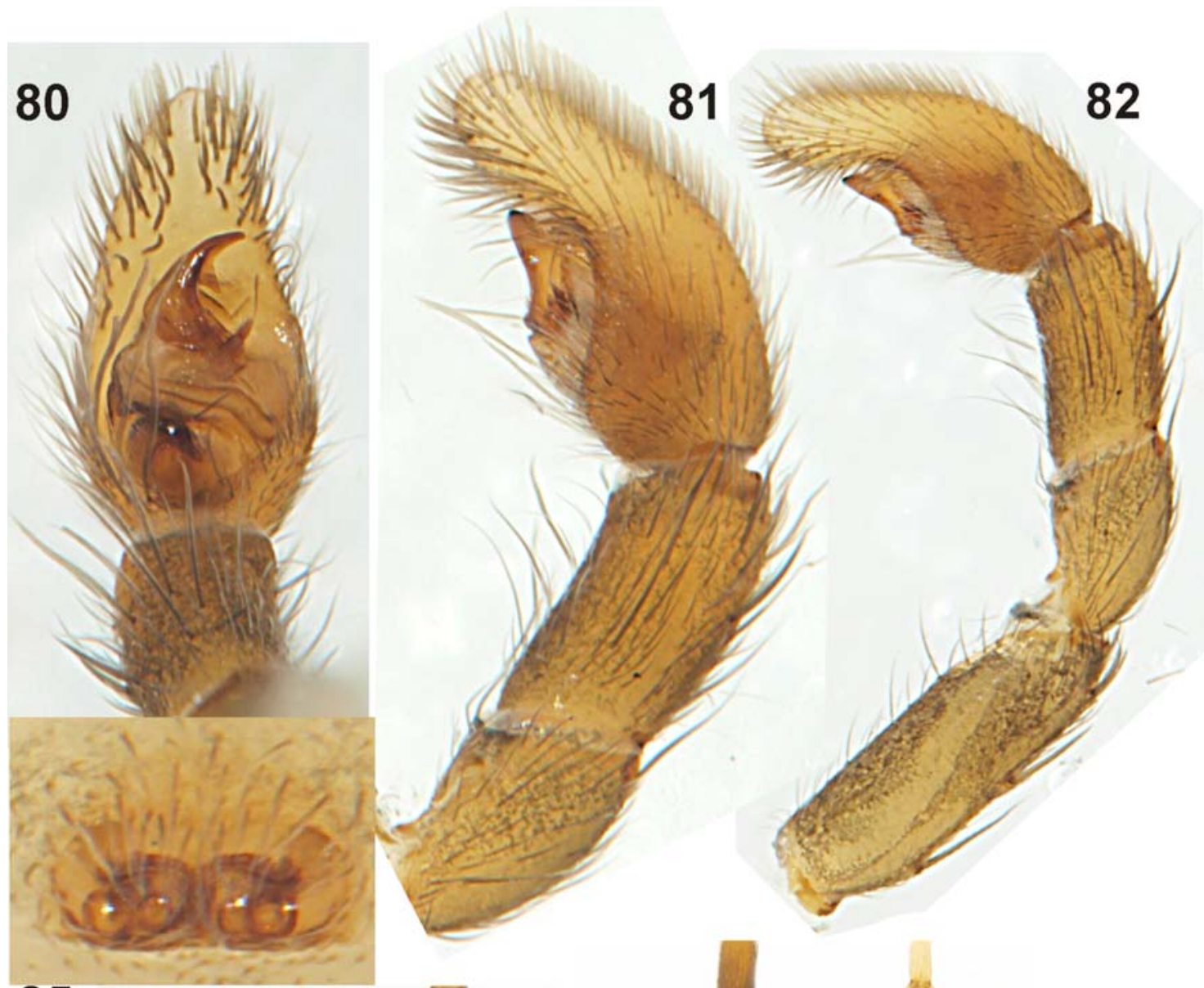

\section{5}

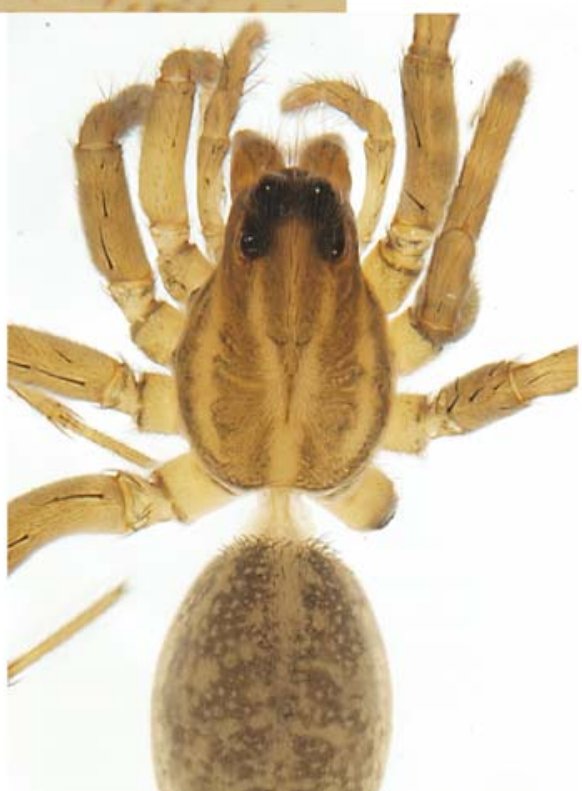

84

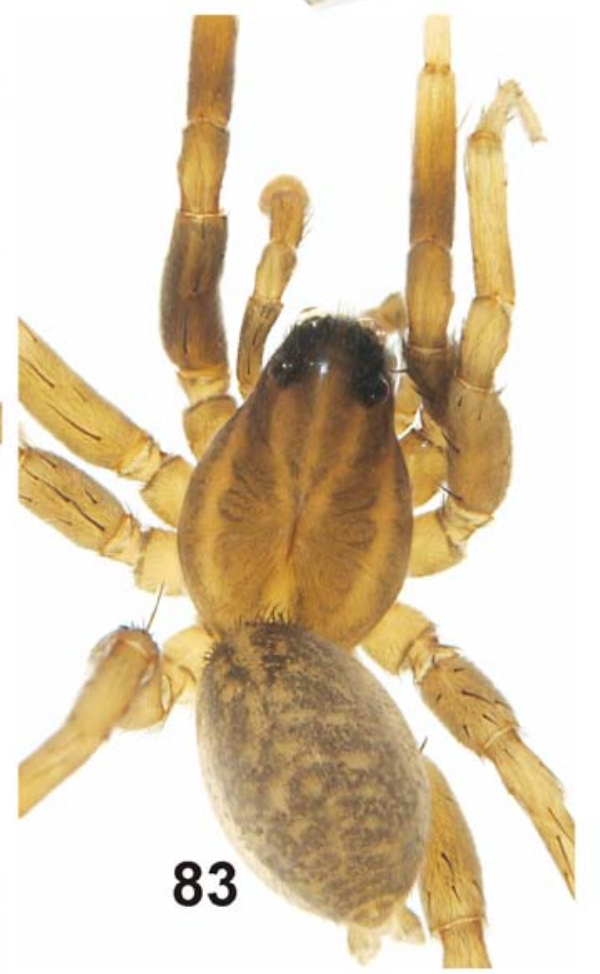

Figs 80-85. Piratula logunovi sp.n.: 80 - palp, ventral view, 81 - palp, retrolateral view; 82 - whole palp; 83 - general appearance of male; 84 - general appearance of female; 85 - epigyne, ventral view.

Рис. 80-85. Piratula logunovi sp.n.: 80 - пальпа, вентрально, 81 - пальпа, ретролатерально; 82 - пальпа целиком; 83 внешний вид самца; 84 - внешний вид самки; 85 - эпигина, вентрально. 
DISTRIBUTION. $P$. praedo is known from the Urals to Kamchatka Peninsula and southward to Tuva, Maritime Province and Hokkaido. In the Nearctic it is known from Yukon Territory to Massachusetts, southward to Illinois [Dondale \& Redner, 1990].

Pirata subpiraticus (Bösenberg \& Strand, 1906) Figs 3d, 27-38, 46-47, 168, 176, Maps 1, 2.

P.s.: Tanaka, 1974: 25, f. 4-6 ( $\left.\sigma^{7}+\right)$.

P. haploapophysis Chai, 1987: 362, f. 1.1-9 ( $\sigma^{7}+$ ). Syn.n.

P.s.: Tanaka, 1988: 39, f. 5-8 ( $\left.\sigma^{\top}+\right)$.

P.s.: Chikuni, 1989: 113, f. $19\left(\mathrm{O}^{\top}+\right)$.

P. blabakensis Barrion \& Litsinger, 1995: 368, f. 216a-f, 217a-h ( $\left.\sigma^{\top}+\right)$. Syn.n.

P. luzonensis Barrion \& Litsinger, 1995: 366, f. 214a-h, 215ah $\left(\sigma^{7}+\right)$. Syn.n.

P.s.: Song et al., 1999: 344, f. 200N, 201E ( $\left.\sigma^{7}+\right)$.

P.s.: Tanaka, 2009: 223, f. 14-15 ( $\left.\sigma^{7}+\right)$.

For more references see Platnick [2011].

MATERIAL EXAMINED. $1 \sigma^{\top}$ (ZMMU), RUSSIA, Maritime Prov., Khasanski Dist., Lotos Lake, 19.07.2004 (M.M. Omelko). 4 O’ $^{\top} 2$ 20 (ZMMU); JAPAN, Osaka Pref., Mozu-umemachi, Sakai-city, 10.07.1979 (H. Tanaka).

DIAGNOSIS. Males of $P$. subpiraticus differ distinctly from other congeners by the shape of their tegular apophysis, which has a long, claw-like outgrowth (Figs 27, 33, 35). Females of this species can be recognized by their long inner pair of receptacula (Figs 46-47) stretching far over the lateral pair of receptacula.

DESCRIPTION. Carapace and abdomen with the typical pattern (Figs 30-31). Marginal stripes yellowish, median band comparatively narrow. Sternum light yellow with three pairs of dark patches along edges (Fig. 3d). Median row of eyes wider than anterior. Abdomen brown with distinct heart mark. Legs without annulations. Chaetotaxy of leg I as shown in Tables 12. Palp as in Figs 27-29, 33-38. Cymbial length/width ratio 2.16. Tegular apophysis unusual for Pirata, with long and thin almost horizontally directed upper part. Pocket of the tegular apophysis slit-like. Subterminal apophysis large and obtuse (Fig. 38). Epigyne and vulva as in Figs 32, 46, 47.

COMMENTS. This species is a new record for Russia, with previous records from Japan, Korea and China. Despite the poor illustrations in the book of Barrion \& Litsinger [1995] it is clear that P. blabakensis Barrion \& Litsinger, 1995, P. luzonensis Barrion \& Litsinger, 1995 and $P$. subpiraticus are conspecific. Therefore, the two former names are treated here as junior synonyms of $P$. subpiraticus. Judging from the figures and description, the Chinese species $P$. haploapophysis Chai, 1987 does not differ from P. subpiraticus and these two names are synonymized.

BIOLOGICAL NOTES. The only specimen of this species was caught in a pitfall trap set on a swampy shore of Lotos Lake. In Japan P. subpiraticus was reported living in small and scanty webs in moist areas of fields or paddy-fields [Tanaka, 1988].

DISTRIBUTION. This species has a South-East Asian distribution and is known from Japan (Hok-

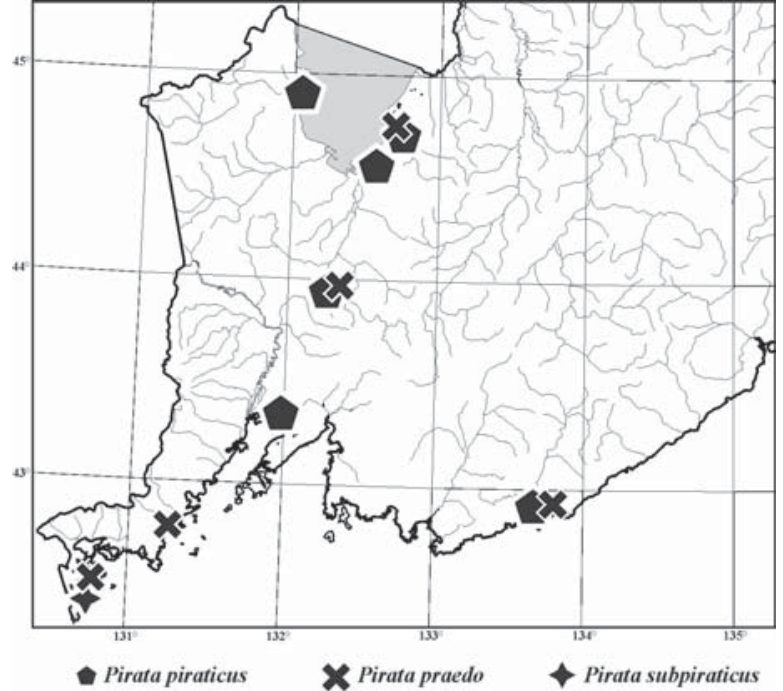

Map. 2. Distribution of species of Pirata in south Primorie: $P$. piraticus $(\boldsymbol{-})$, P. praedo $(\boldsymbol{X})$ and $P$. subpirticus $(\bullet)$.

Карта 2. Распространение видов рода Pirata в южном Приморье: Pirata piraticus (-), P. praedo $(\boldsymbol{X})$ and $P$. subpirticus $(\triangleleft)$

kaido, Honshu Shikoku and Kyushu), South Korea, China, Philippines and Maritime Province of Russia.

Pirata tenuitarsis Simon, 1876

Figs 44-45, Map 1.

P.t.: Kronestedt, 1980: 66, f. 2B, 3A, C, 4B-C, 6D-F, 7A-C, 8A-D, 9A-B, 10A $\left(\sigma^{7}+\right)$.

P.t.: Logunov, 1992: 61, f. $6\left(\sigma^{\top} 0\right)$.

P.t.: Roberts, 1998: 250, f. ( $\left.\sigma^{7}+\right)$.

P.t.: Almquist, 2005: 245, f. 240a-e ( $\sigma^{7}$ ).

For more references see Platnick [2011].

MATERIAL EXAMINED. MONGOLIA: $2 \sigma^{\top} \sigma^{\top} 1$ q (ZMMU), Tov Aimak, $48^{\circ} 22^{\prime} \mathrm{N} 106^{\circ} 18^{\prime} \mathrm{E}, 1100 \mathrm{~m}, 18-23.06 .1997$ (Y.M. Marusik).

DIAGNOSIS. This species is closely related to $P$. piraticus. For differences between these species see Kronestedt [1980].

DESCRIPTION. This species was well described by Kronestedt [1980]. Marginal stripes wide, yellowish. Abdomen brown with heart mark and several pairs of white spots. Legs without annulations. Chaetotaxy of female's leg I as shown in Table 2. Epigyne and vulva as in Figs 44-45.

COMMENTS. This species doesn't occur in the Far East and is documented here for comparison with the other species.

BIOLOGICAL NOTES. As in most of Pirata and Piratula this species occurs in various damp habitats.

DISTRIBUTION. This species occurs from Europe to Mongolia.

Genus Piratula Roewer, 1960

Type species Pirata hygrophila Thorell, 1872 from Sweden. 

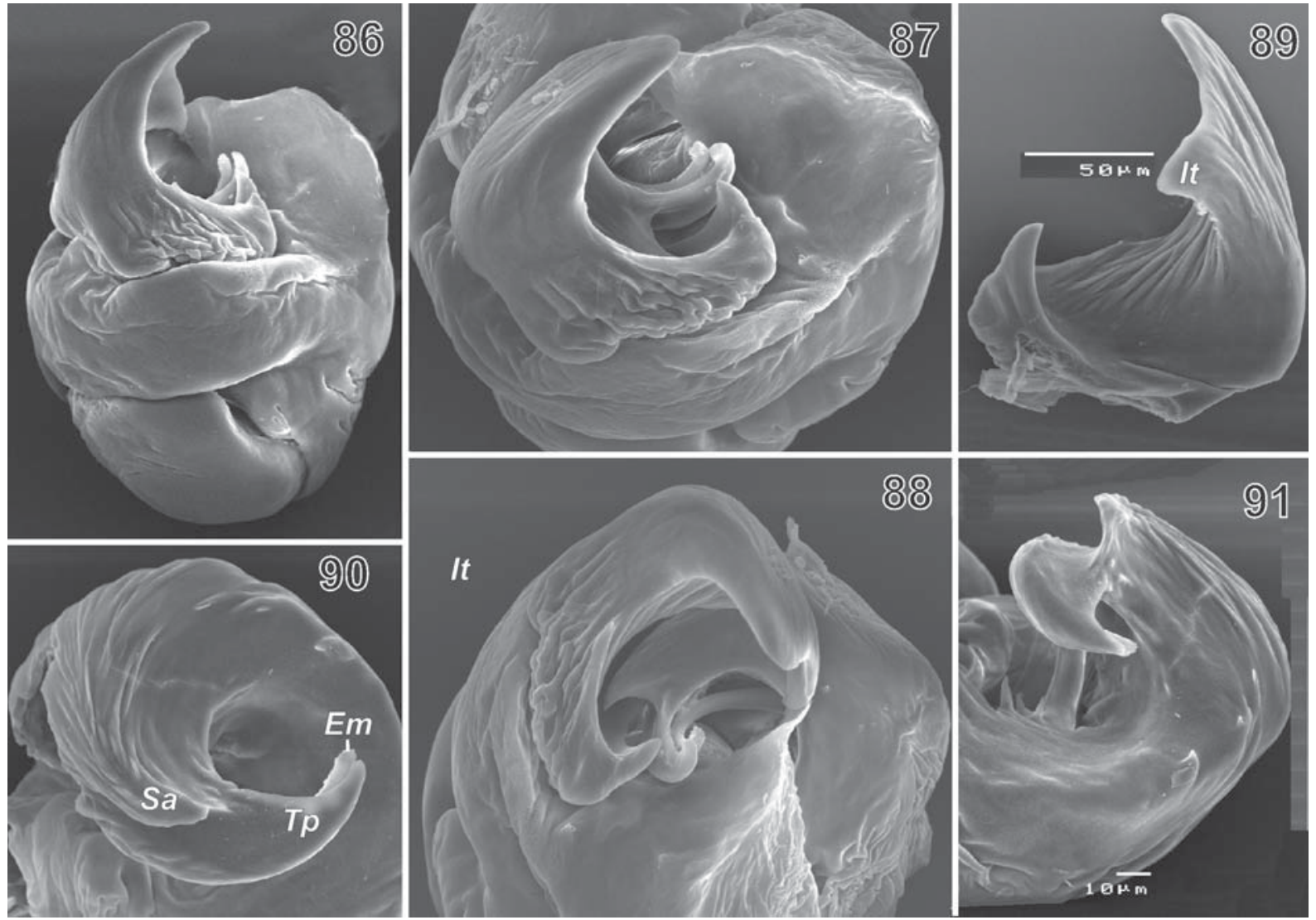

Figs 86-91. Bulbus of Piratula logunovi sp.n. : 86 - ventral view, 87 - tegular apophysis, view from above, 88 - retrolateral view, 89 - apophysis, dorsal view; 90, 91 - terminal apophysis.

Рис. 86-91. Бульбус Piratula logunovi sp.n.: 86 - вентрально; 87 - тегулярный отросток, вид сверху, 88 - ретролатерально, 89 - дорсально; 90, 91 - терминальный апофиз.

COMMENTS. Roewer [1960] distinguished this genus mainly on the basis of its eye formula: procurved first eye row (straight in Pirata) and relative size of AME and ALE (equal in Piratula and AME $>$ ALE in Pirata).

The genus was synonymized with Pirata by Dondale \& Redner [1981] because the two genera have a similar conformation of the embolic part of the pedipalp (the resting embolus lies in a groove formed by the folded margin of the terminal apophysis). Subsequently, Piratula was considered as a valid genus only in two papers, by Zyuzin [1985] and by Logunov [1991]. Zyuzin [1985] confirmed that the two genera differ in their eye arrangement: width of anterior eye row equal to width of PME in Pirata, and shorter in Piratula. Logunov [1991] mentioned differences in eye formula and also indicated differences in the male palps.

Study of several species of Pirata and Piratula revealed that these two genera have many differences in the male palp: relative size and position of subtegulum, size and conformation of the tegular apophysis, shape of terminal apophysis. Some differences were found in sternal patterns and in leg I spination in females. Therefore, we remove Piratula from synonymy with Pirata.
The Far Eastern Piratula and Pirata can be easily distinguished from one another by their size. All Pirat$u l a$ are smaller than Pirata (Figs 178-179).

DIAGNOSIS. Males of Piratula can be easily distinguished from Pirata by their shorter tegular height (less than $1 / 2$ of tegulum height), large $\mathrm{C}$-shaped tegular apophysis (larger than subtegulum) which is longer than wide (cf. Figs 158-169). Most species have a tooth (sometimes two) on the upper arm of the tegular apophysis. Most species can be separated by the pattern on the sternum: uniformly coloured or with dark sublateral spots in Pirata and light sublateral spots in Piratula (cf. Figs 3-5). Females of Piratula can be separated from those of Pirata by having a prolateral tibial spine on leg I (absent in Pirata).

There are several other differences. "Subterminal" apophysis in Pirata is well developed and it is sharply pointed. In Piratula this apophysis is undeveloped and represented by a bulge or ridge. All Pirata have a diagonal course of the seminal duct in the tegulum, whereas in Piratula it is almost transverse (except in $P$. hygrophila where it follows a S-shaped course).

NOTE. Among a relatively homogenous group, the type species of the genus is somewhat dissimilar from the remaining species. Among the Far Eastern species 


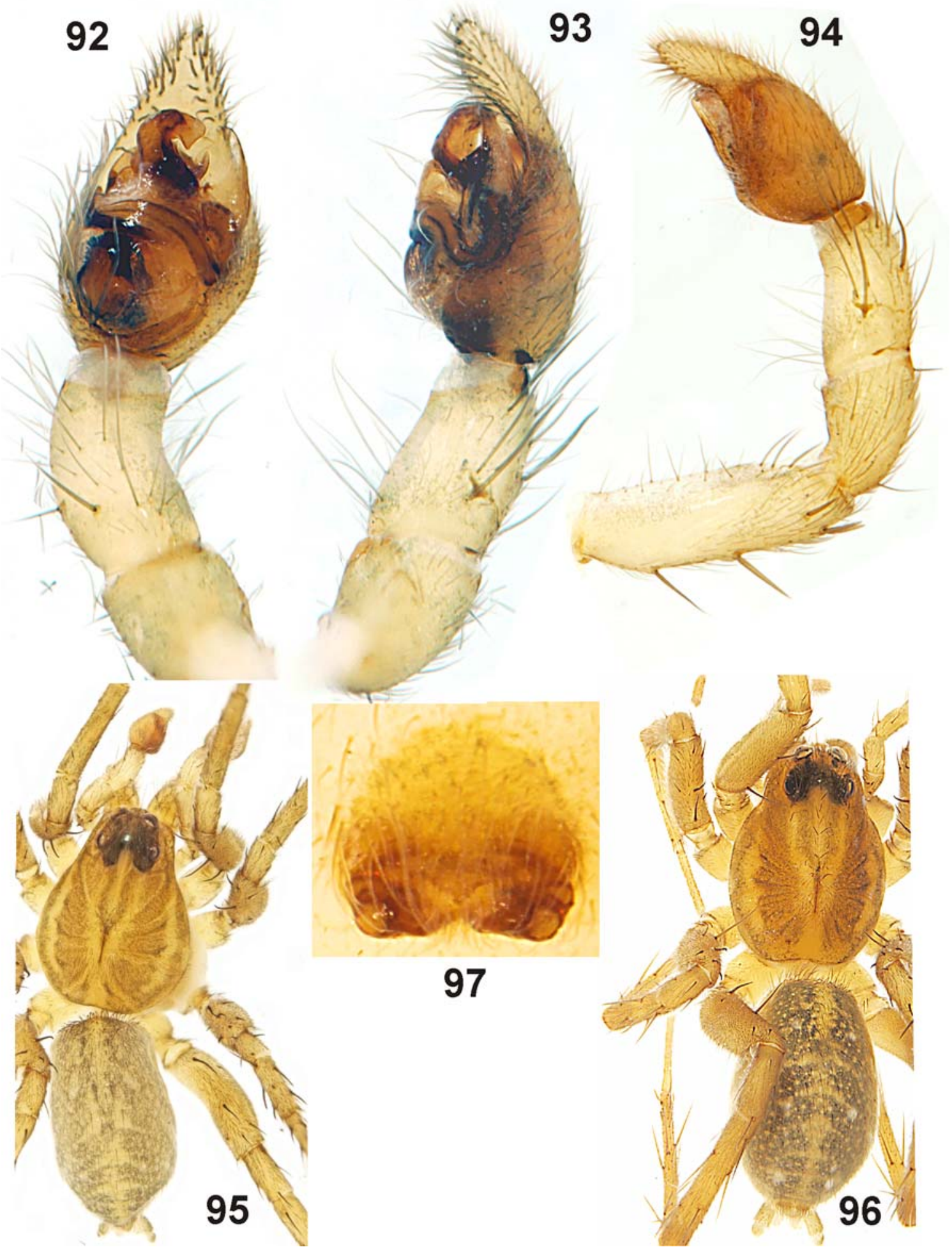

Figs 92-97. Piratula meridionalis: 92 - palp, ventral view, 93 — palp, retrolateral view; 94 - whole palp; 95 — general appearance of male; 96 - general appearance of female; 97 - epigyne, ventral view.

Pис. 92-97. Piratula meridionalis: 92 - пальпа, вентрально, 93 - пальпа, ретролатерально; 94 — пальпа целиком; 95 внешний вид самца; 96 - внешний вид самки; 97 - эпигина, вентрально. 

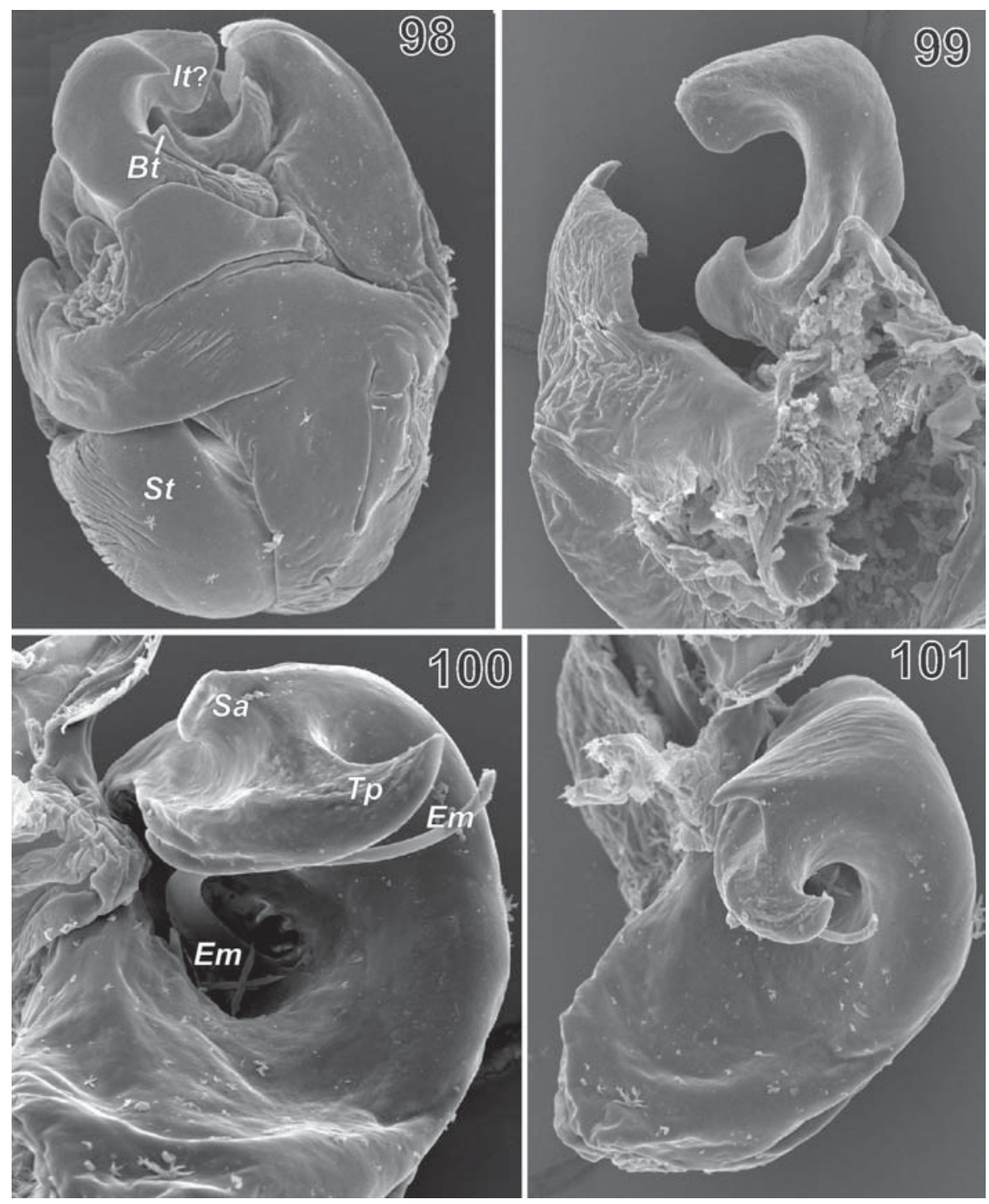

Figs 98-101. Bulbus of Piratula meridionalis: 98 — ventral view; 99 - tegular apophysis, dorsal view; 100,101 — terminal apophysis.

Рис. 98-101. Бульбус Piratula meridionalis: 98 — вентрально; 99 — тегулярный отросток, дорсально; 100,101 — терминальный апофиз.

only Piratula meridionalis deviates in its morphology (shape of the tegular apophysis and sharply pointed subterminal apophysis).

COMPOSITION. Here we transfer to Piratula only 25 species that we were able to examine or species that are well illustrated. Three of them, including the type species were already placed in Piratula by Roewer [1960]. Including the new species described here, the total number of species in the genus is 26: Piratula hygrophila (Thorell, 1872), Piratula borea (Tanaka, 1974) comb.n., Piratula canadensis (Dondale \& Redner, 1981) comb.n., Piratula cantralli (Wallace \& Exline, 1978) comb.n., Piratula clercki (Bösenberg \& Strand, 1906) comb.n., Piratula denticulata (Liu, 1987) comb.n., Piratula gigantea (Gertsch, 1934) comb.n., Piratula hiroshii (Tanaka, 1986) comb.n., Piratula hokkaidensis (Tanaka, 2003) comb.n., Piratula hurkai (Buchar, 1966) comb.n., Piratula insularis (Emerton, 1885) comb.n., Piratula iriomotensis (Tanaka, 1989) comb.n., Piratula knorri (Scopoli, 1763), Piratula latitans (Blackwall, 1841), Piratula logunovi sp.n., Piratula longjiangensis (Yan, Yin, Peng, Bao \& Kim, 1997) comb.n., Piratula meridionalis (Tanaka, 1974) comb.n., Piratula minuta (Emerton, 1885) comb.n., Piratula montigena (Liu, 1987) comb.n., Piratula piratoides (Bösenberg \& Strand, 1906) comb.n., Piratula procurva (Bösenberg \& Strand, 1906) comb.n., Piratula serrulata (Song \& Wang, 1984) comb.n., Piratula tanakai (Brignoli, 1983) comb.n., Piratula tenuisetacea (Chai, 1987) comb.n., Piratula yaginumai (Tanaka, 1974) comb.n. and Piratula yesoensis (Tanaka, 1985) comb.n. - all ex Pirata. Some of these names may be synonyms. 


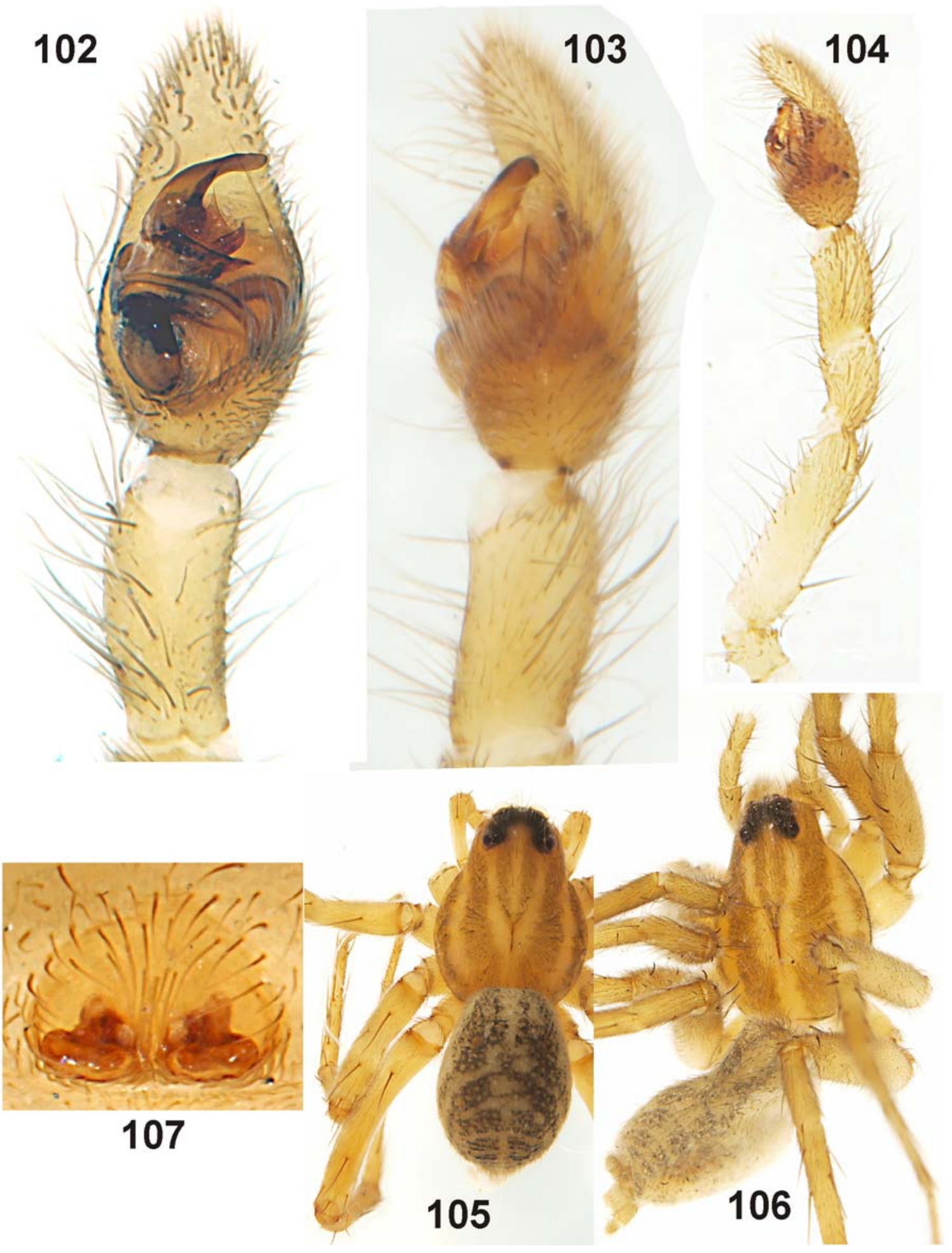

Figs 102-107. Piratula piratoides: 102 - palp, ventral view, 103 — palp, retrolateral view; 104 — whole palp; 105 — general appearance of male; 106 - general appearance of female; 107 - epigyne, ventral view.

Рис. 102-107. Piratula piratoides: 102 — пальпа, вентрально, 103 — пальпа, ретролатерально; 104 — пальпа целиком; 105 внешний вид самца; 106 - внешний вид самки; 107 - эпигина, вентрально. 

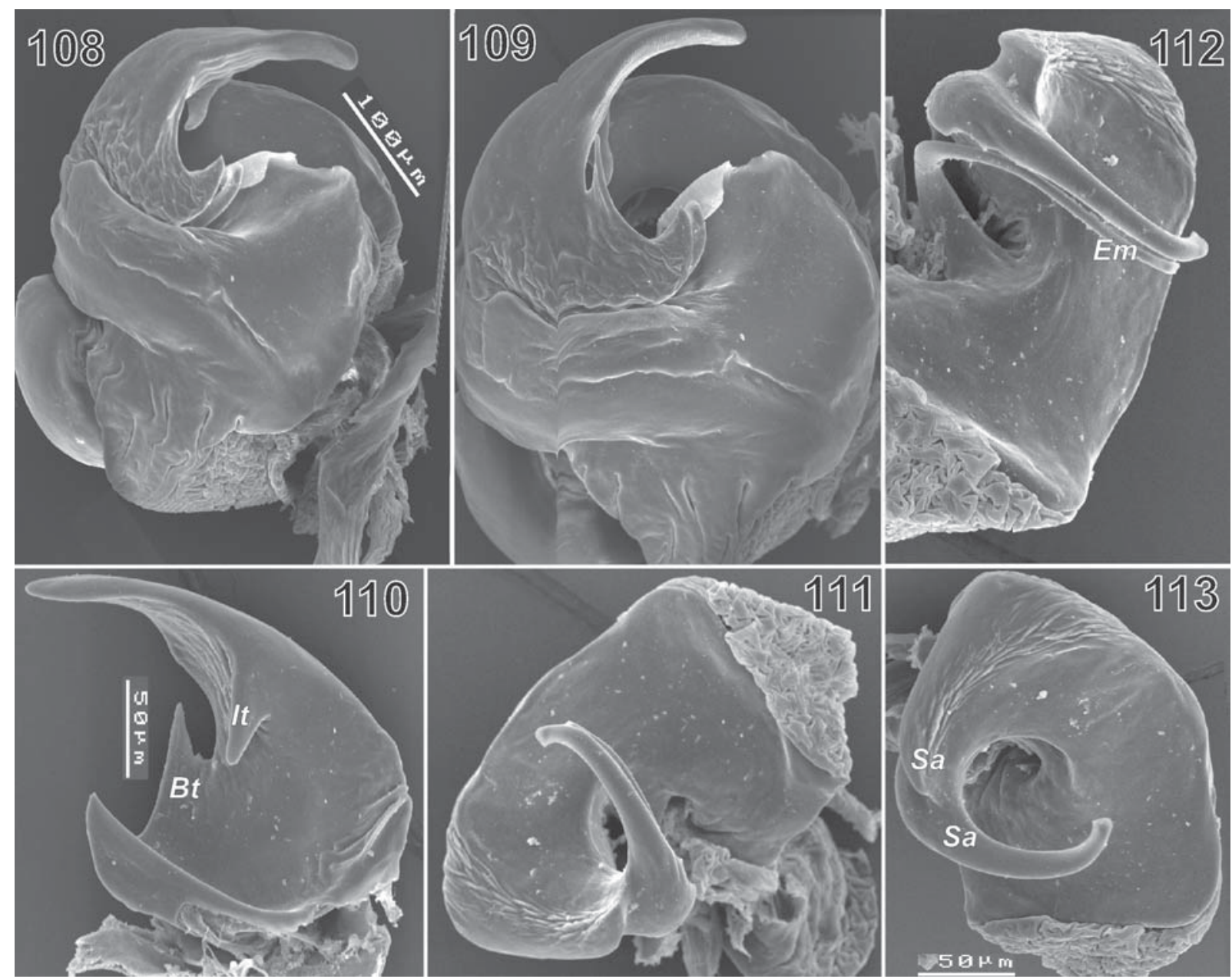

Figs 108-113. Bulbus of Piratula piratoides: 108 - retrolateral view, 109 - ventral view; 110 — tegular apophysis, dorsal view; 111-113 - terminal apophysis.

Рис. 108-113. Бульбус Piratula piratoides: 108 — ретролатерально, 109 — вентрально; 110 — тегулярный отросток, дорсально; 111-113 - терминальный апофиз.

It is worth mentioning that Roewer [1954] listed 15 species of Piratula in his catalogue, some of which we consider correctly placed: $P$. clercki, $P$. piratoides and $P$. procurva, while some of them we consider to belong in true Pirata: $P$. praedo, $P$. subpiraticus. The generic position of the other species is unclear to us. The species listed in the catalogue cannot be considered as former member of Piratula, because that genus was not described at that time.

While describing the new genus, Roewer [1960] assigned only seven species to Piratula: P. hygrophila, P. knorrii, P. latitans, P. kempi (Gravely, 1924), P. sedentaria (Montgomery, 1904), P. chamberlini (Lessert, 1927) and P. werneri Roewer, 1960.

Five Nearctic species listed in Pirata: P. bryantae (Kurata, 1944), P. montanoides Banks, 1892, P. montanus Emerton, 1885, P. sedentarius Montgomery, 1904 and $P$. seminolus Gertsch \& Wallace, 1935 may also belong to Piratula or to undescribed genera. These five species have a small subtegulum and a subhorizontal seminal duct, but the subtegulum is located prolaterally, and the tegular apophysis is not C-shaped.

Piratula borea (Tanaka, 1974), comb.n. Figs $48-52$.

Pirata boreus Tanaka, 1974: 33, f. 18-20 (O'ㅇ).

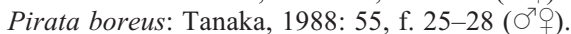

Pirata boreus: Tanaka, 2009: 225, f. 26-27 (O'P).

MATERIAL EXAMINED. JAPAN: $10^{7} 2$ 우 (ZMMU), Akita Prefecture, Tennou-cho, Shitudo Marsh, 21.07.2002 (A. Fukushima).

DIAGNOSIS. By structure of palpal organs males of $P$. borea differs well from all congeners except for P. meridionalis (Tanaka, 1974). These two species have an unusually large tegular apophysis, but in $P$. borea its tip is wide, whereas in P. meridionalis it is comparatively narrow. Females of $P$. borea resemble these of $P$. meridionalis, $P$. serrulata and $P$. logunovi sp.n. but can be distinguished from them by the structure of epigyne and vulva. 


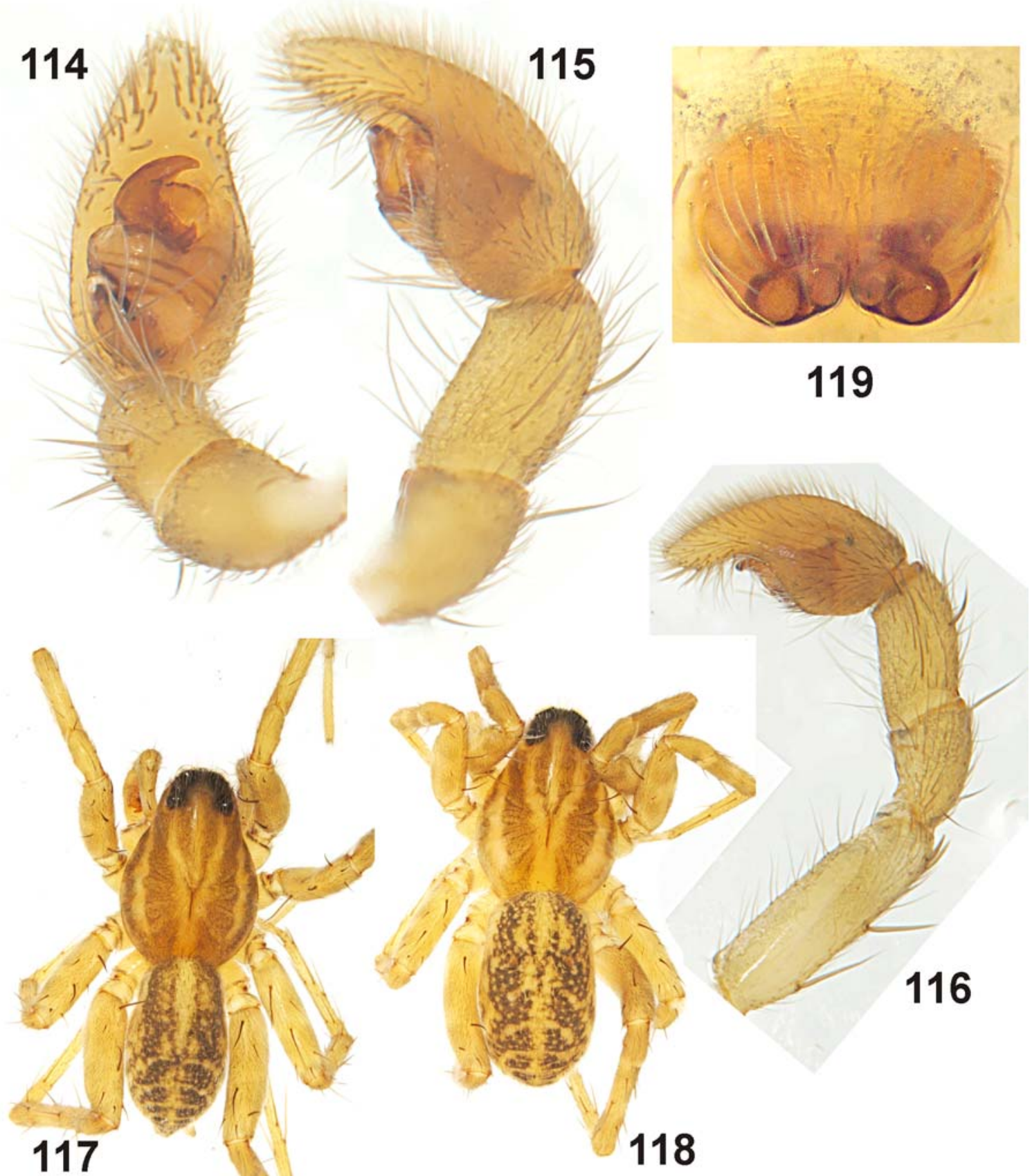

Figs 114-119. Piratula serrulata: 114 - palp, ventral view, 115 — palp, retrolateral view; 116 — whole palp; 117 — general appearance of male; 118 - general appearance of female; 119 - epigyne, ventral view.

Рис. 114-119. Piratula serrulata: 114 - пальпа, вентрально, 115 - пальпа, ретролатерально; 116 — пальпа целиком; 117 внешний вид самца; 118 - внешний вид самки; 119 - эпигина, вентрально.

DESCRIPTION. This species was well described by Tanaka [1974, 1988]. Carapace and abdomen with pattern as in Figs 50-51. Edges of carapace with dark marginal stripes. Submarginal stripes light, as wide as marginal. Submedian bands dark brown. Abdomen brown with distinct heart mark. Legs with indistinct annulations. Chaetotaxy of leg I as shown in Tables 12. Palp as in Figs 48-49. Cymbial length/width ratio
1.68. Tibia curved, shorter than cymbium. Tegular apophysis large with wide tip. Subtegulum located almost centrally. Epigyne as in Fig. 52.

COMMENTS. This species does not occur in the Russian Far East and is documented here for comparison with the other species. Comparative study of material collected from Maritime Province and Japan revealed that the previous record of $P$. borea in Russia 

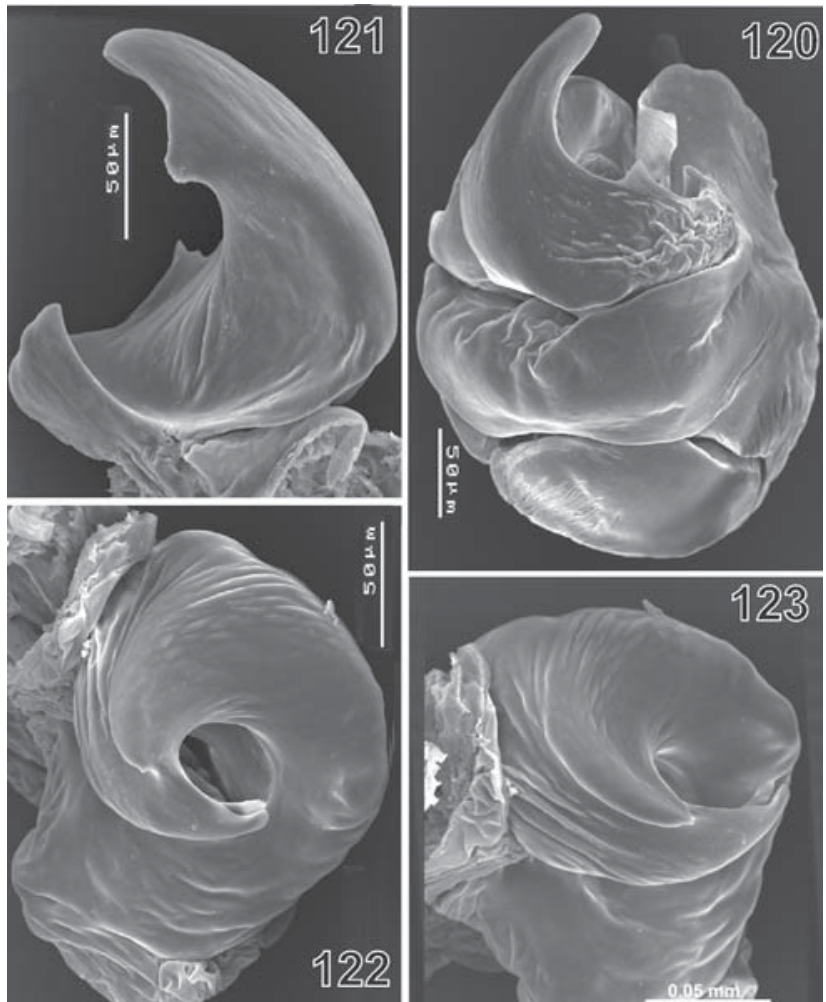

Figs 120-123. Bulbus of Piratula serrulata: 120 - ventral view, 121 - tegular apophysis, dorsal view; 122, 123 - terminal apophysis.

Рис. 120-123. Бульбус Piratula serrulata: 120 - вентрально, 121 - тегулярный отросток, дорсально; 122, 123 - терминальный апофиз.
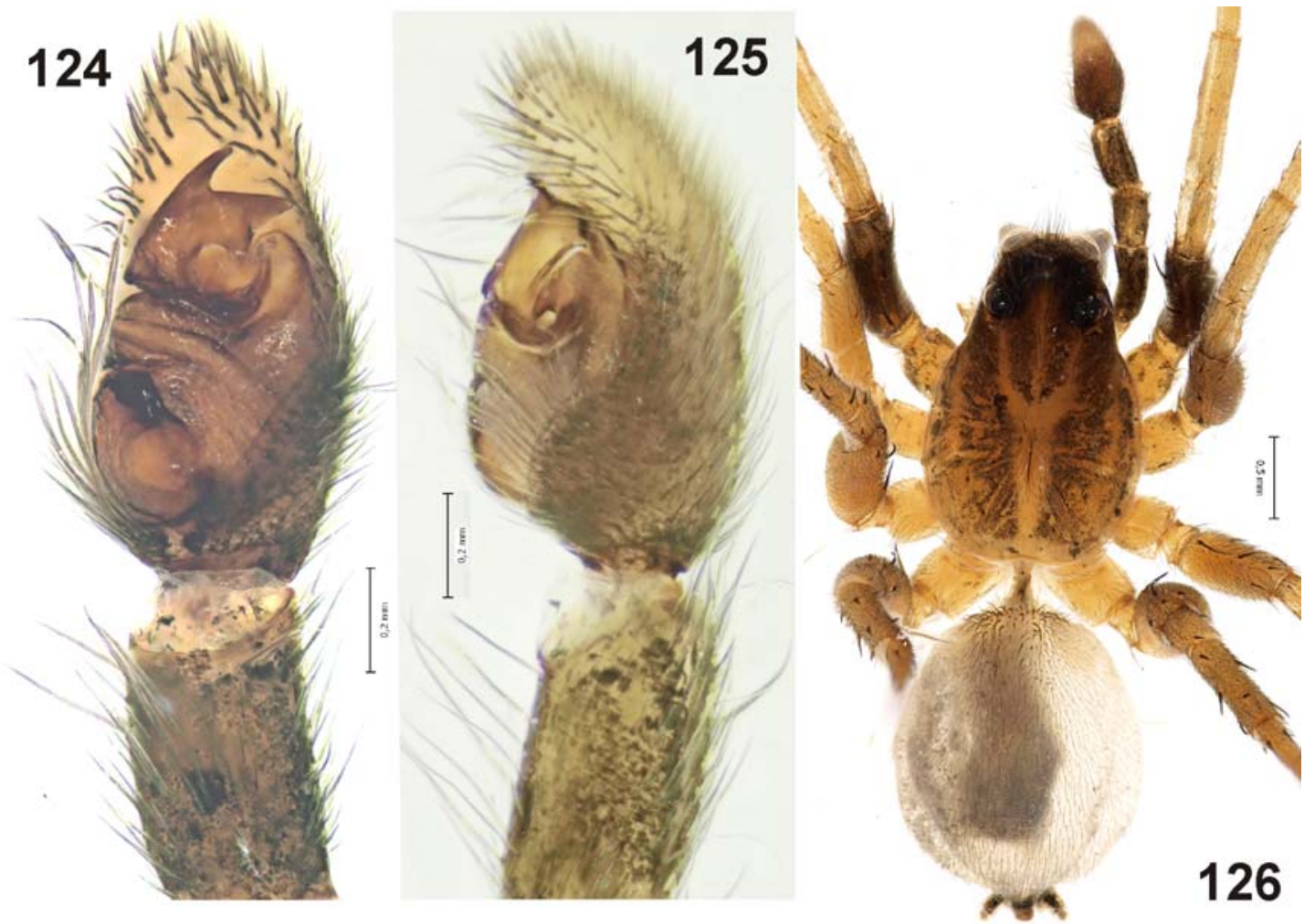

Figs 124-126. Piratula tanakai: 124 - palp, ventral view, 125 — palp, retrolateral view; 117 — general appearance of male. Рис. 124-126. Piratula tanakai: 124 - пальпа, вентрально, 125 - пальпа, ретролатерально; 117 - внешний вид самца. 

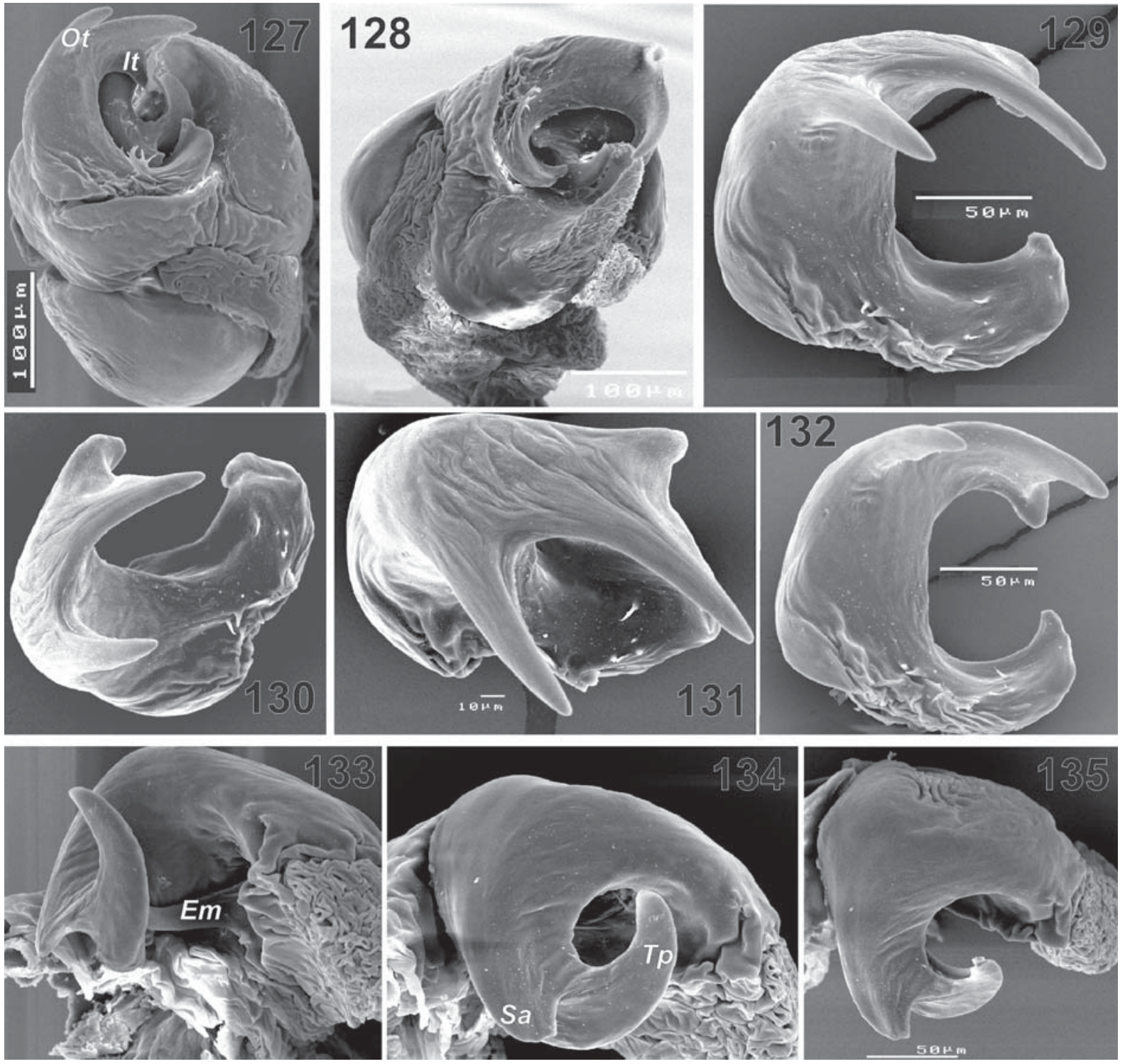

Figs 127-135. Bulbus of Piratula tanakai: 127 - ventral view, 128 - retrolateral view; 129, 132 - tegular apophysis, ventral view, 130 - retrolateral view, 131 - view from above; $133-135$ - terminal apophysis.

Рис. 127-135. Бульбус Piratula tanakai: 127 - вентрально, 128 - ретролатерально; 129, 132 - тегулярный отросток, вентрально, 130 - ретролатерально, 131 - вид сверху; 133-135 - терминальный апофиз.

[Marusik, Koponen, 2000] is the result of a misidentification and these specimens actually belong to $P$. serrulata. Judging from the figures and distribution of these species all records of $P$. borea in China [Song et al., 1999] probably refer to $P$. serrulata .

BIOLOGICAL NOTES. In Japan $P$. borea inhabits the shores of ponds [Tanaka, 1988].

DISTRIBUTION. This species is known from Japan (Hokkaido) and northeastern China (Jilin Province). Records from China most probably refer to another species.
Piratula canadensis (Dondale \& Redner, 1981), comb.n.

Figs 4b, 53-64, 146-147, 158, Map 1.

Pirata c. Dondale \& Redner, 1981: 194, f. 1-8 ( (

Pirata c.: Dondale \& Redner, 1990: 251, f. 366-373 ( $0^{7}+$ ).

Pirata c.: Paquin \& Dupérré, 2003: 167, f. 1870-1873 ( $0^{2}+$ ).

P. aff. canadensis: Marusik et al. 2010: 288.

MATERIAL EXAMINED. RUSSIA: Khabarovsk Prov.: $30^{7} 0^{7}$ (ZMMU), Bureinski Reserve, $3.5 \mathrm{~km}$ downstream of Pravaya Bureya River mouth, 15-16.06.2001 (L. Trilikauskas); 1 (ZMMU), Bureinski Reserve, valley of Levaya Bureya River, near Chaphoz River mouth, lake shore (L. Trilikauskas). Kamchatka Area: $10^{7}$ (ZMMU), Koryakia, environs of Tigil Vil., ca $57^{\circ} 46^{\prime} \mathrm{N}, 158^{\circ} 40^{\prime} \mathrm{E}$, 

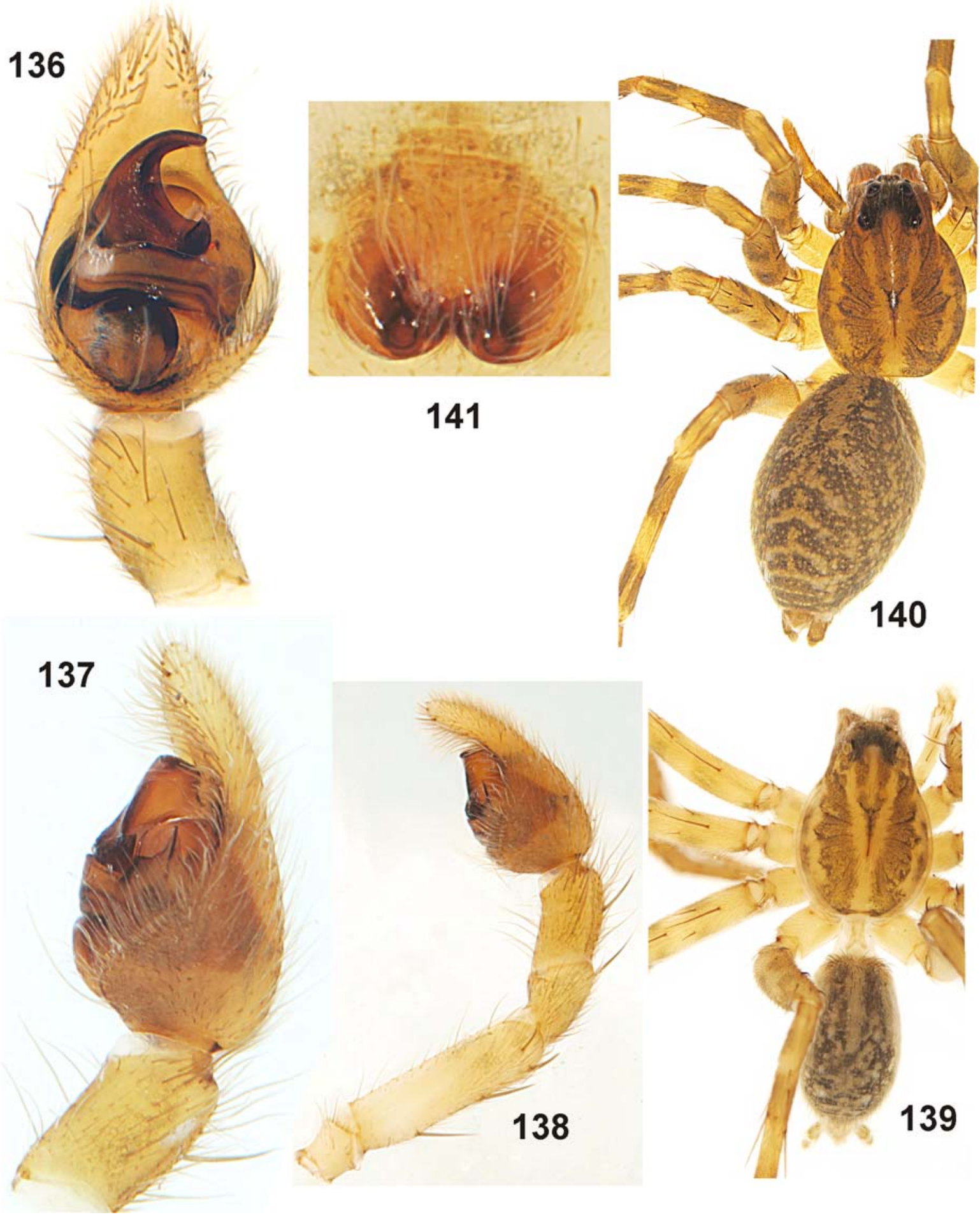

Figs 136-141. Piratula yaginumai: 136 — palp, ventral view, 137 — palp, retrolateral view; 138 — whole palp; 139 — general appearance of male; 140 - general appearance of female; 141 - epigyne, ventral view.

Pис. 136-141. Piratula yaginumai: 136 - пальпа, вентрально, 137 - пальпа, ретролатерально; 138 - пальпа целиком; 139 внешний вид самца; 140 - внешний вид самки; 141 — эпигина, вентрально. 

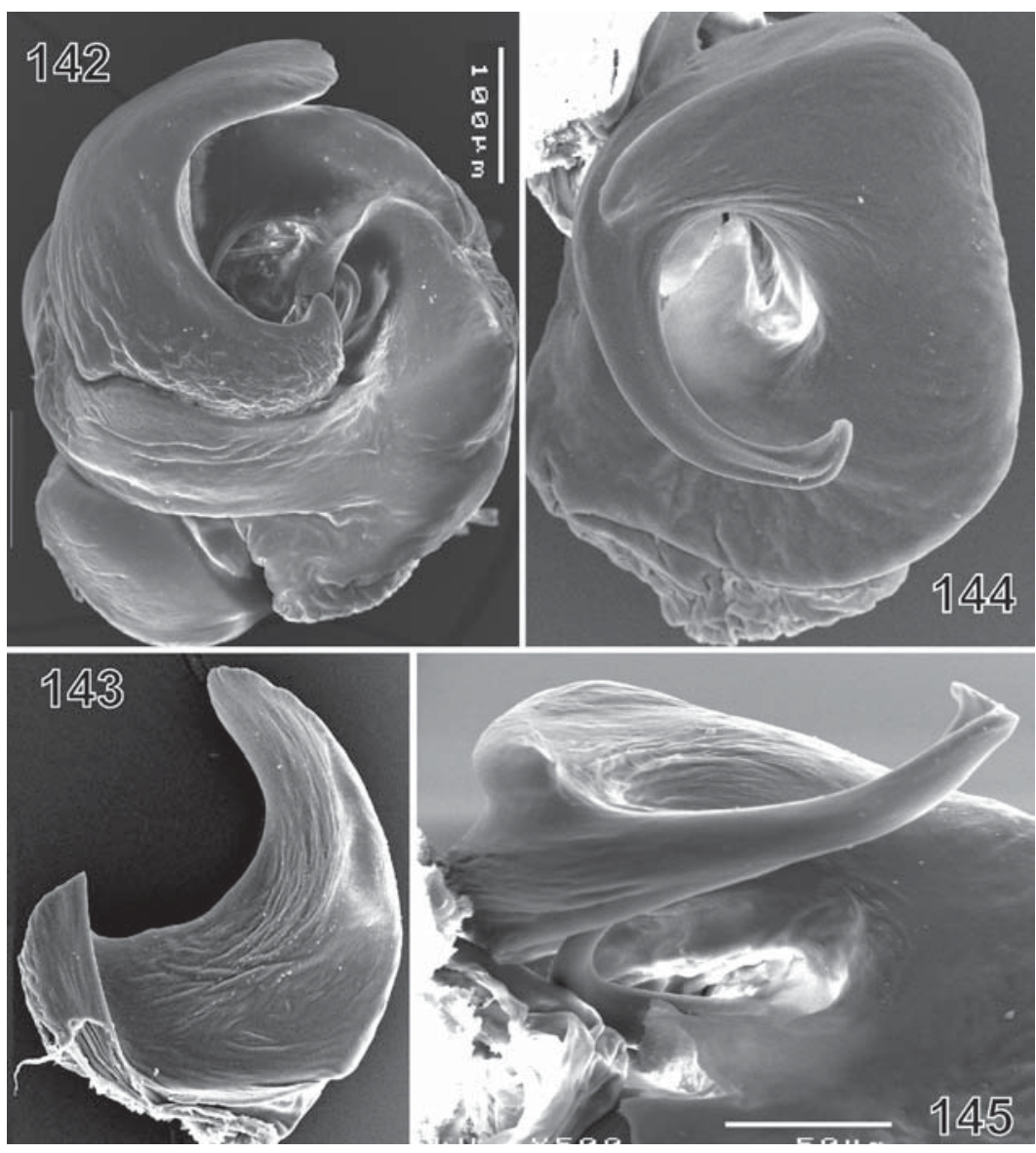

Figs 142-145. Bulbus of Piratula yaginumai: 142 - ventral view, 143 - tegular apophysis, dorsal view; 144, 145 - terminal apophysis.

Рис. 142-145. Бульбус Piratula yaginumai: 142 — вентрально, 143 — тегулярный отросток, дорсально; 144, 145 — терминальный апофиз.

07.07-05.08.2010 (A.S. Ryabukhin). CANADA: 6 우 (ZMUT), Quebec Prov., St. Charles, bog 30.05-1.11.1990 (S. Koponen).

DIAGNOSIS. $P$. canadensis can be easily distinguished from other Piratula by its very small body size (the smallest species in the region - male: $3 \mathrm{~mm}$, female: $3.5 \mathrm{~mm}$ ) and by the structure of the copulatory organs.

DESCRIPTION. This species was well described by Dondale \& Redner [1990]. Carapace and abdomen with pattern as in Figs 55-57. Marginal stripes narrow, almost unnoticeable in specimens from Khabarovsk Province. Submarginal stripes light, as wide as submedian bands, median band light brown. Sternum dark brown with yellowish longitudinal stripe and three pairs of spots (Fig. 4b). Abdomen brown with heart mark. In male from Kamchatka it bears a V-shaped mark behind the heart mark. Legs without annulations. Chaetotaxy of leg I as shown in Tables 1-2. Palp as in Figs 53-54, 59-64. Cymbial length/width ratio 1.57. Tibia straight, shorter than cymbium. Tegular apophysis curved with pointed tip. Inner tooth very long, basal tooth minute. Subterminal apophysis small and ridge-like. Epigyne and vulva as in Figs 58, 146, 147. Receptacula dropletshaped.
COMMENTS. This species was found and recognized for the first time in Russia by our colleague Laimonas Trilikauskas (personal communication). It represents a new species record for Russia, with previous records only from Canada.

BIOLOGICAL NOTES. In Canada this species inhabits sphagnum bogs. Specimens from Khabarovsk Province were found on lake shores.

DISTRIBUTION. This species has an East Asian Nearctic range and occurs in Canada (from British Columbia to Nova Scotia) and the Far East of Russia (Kamchatka and Khabarovsk Province).

Piratula hygrophila (Thorell, 1872)

Figs 2a, 65-70, 163, Map 1. $1\left(O^{7}+\right)$

Pirata hygrophilus: Holm, 1947: 9, f. 7a, pl. 1, f. 3-4, pl. 9, f.

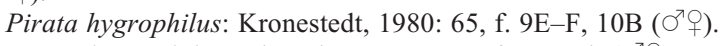

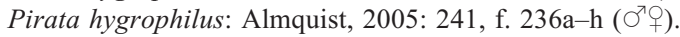

For more references see Platnick [2011].

MATERIAL EXAMINED. KAZAKHSTAN: $190^{7} 0^{7} 20$ 우 (MMUM), East Kazakhstan Area, SW part of Tarbagatai Mt. Range;

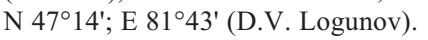




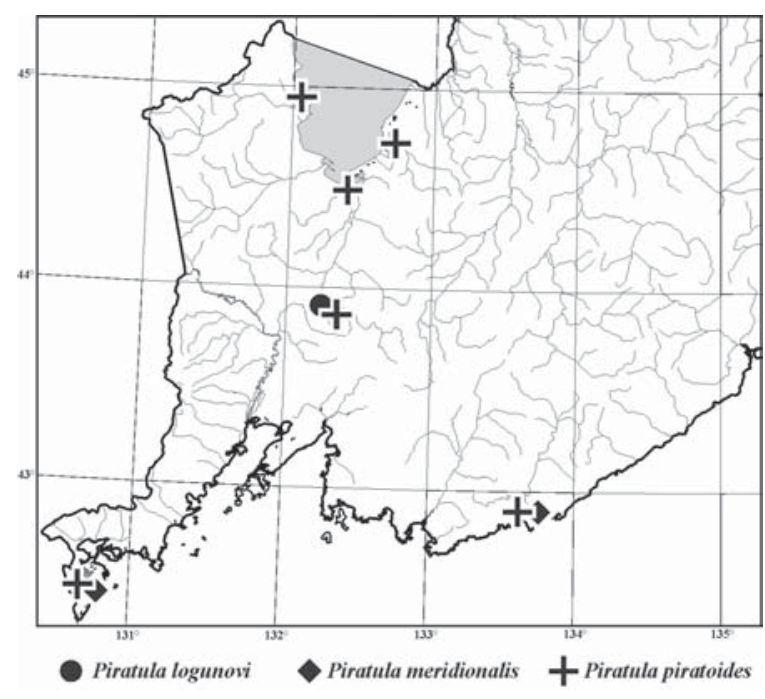

Map. 3. Distribution of species of Piratula in south Primorie: $(+)$.

P. logunovi sp.n. (๑), P. meridionalis $(\diamond)$ and P. piratoides

Карта 3. Распространение видов рода Piratula в южном Приморье: P. logunovi sp.n. (๑), P. meridionalis $(\bullet)$ and P. piratoides $(\mathbf{+})$.

DIAGNOSIS. This species is most similar to $P$. hiroshii Tanaka, 1986 known from Japan. Males can be distinguished by their more curved tegular apophysis. Females are easily differentiated by the structure of the epigyne and vulva.

DESCRIPTION. This species was well described by Nadolny \& Kovblyuk [2011] in the current issue. Carapace and abdomen with pattern as in Figs 68-69. General coloration dark, male darker than female. Marginal stripes narrow, submarginal stripes light and of the same width. Submedian bands dark brown, median band light brown. Eye arrangement as in Fig. 2a. Median row of eyes wider than anterior. Abdomen brown with heart mark and series of strokes (in males) or spots (in females). Legs with distinct annulations. Chaetotaxy of leg I as shown in Tables 1-2. Palp as in Figs 65-67. Cymbial length/width ratio 1.39. Tibia straight, shorter than rather broad cymbium. Tegular apophysis broad, sickle-shaped. Inner tooth very broad, directed almost horizontally. Epigyne as in Fig. 70.

COMMENTS. This species does not occur in the Far East and is documented here because it is the type species of Piratula.

BIOLOGICAL NOTES. This species inhabits fens, bogs and damp meadows [Almquist, 2005].

DISTRIBUTION. This species has a West Palaearctic range and occurs west of the Yenisei River [Marusik et al., 2000].

\section{Piratula insularis (Emerton, 1885), comb.n.} Figs 71-79, 154-155, 166, Map 1.

Pirata piccolo: Holm, 1947: 10, pl. 1, f. 9-10, pl. 9, f. 5 ( ( Pirata piccolo: Kronestedt, 1980: 65, f. 9I, K $\left(\sigma^{7}\right)$.

Pirata i.: Dondale \& Redner, 1990: 255, f. 380-386 (○ㅇ).
Pirata i.: Paquin \& Dupérré, 2003: 167, f. 1878-1881 ( $\sigma^{7}+$ ).

Pirata i.: Almquist, 2005: 241, f. 237a-e ( $\sigma^{\top}+$ ).

For more references see Platnick [2011].

Faunistic records. Pirata piccolo: Eskov [1988].

MATERIAL EXAMINED. FINLAND: $1 \sigma^{7}$ (ZMUT, ARA 27035) Turku, Kärsämäki, Pomponrahka, (I. Oksala); 1 o 2 우 (ZMUT), same locality, 30.06.1966 (M. Saaristo); $4 \sigma^{\top} \sigma^{\top} 1$ q (ZMUT), Tarvasjoki, Juvarahka, 01.09.1968 (M. Saaristo).

DIAGNOSIS. This species is most similar to $P$. canadensis but differs from it by its larger body size. From other congeners it can be distinguished by the structure of the copulatory organs.

DESCRIPTION. This species was well described by Holm [1947], Kronestedt [1980] and in the other papers mentioned above. Carapace and abdomen with pattern as in Figs 73-74. Marginal stripes narrow, dark brown. Submarginal stripes light, as wide as submedian bands, median band light brown. Abdomen brown with heart mark, V-mark in males, series of spots in females. Legs without annulations. Chaetotaxy of leg I as shown in Tables 1-2. Palp as in Figs 71-72, 76-79. Cymbial length/width ratio 1.60 . Tibia more or less straight, shorter than cymbium. Tegular apophysis curved with pointed tip. Inner tooth very long and narrow (Figs 77-78). There are two basal teeth, one of which is comparatively large, another is minute, noticeable only from behind (Fig. 78). Subterminal apophysis small and obtuse. Epigyne and vulva as in Figs 75, 154-155. Receptacula droplet-shaped.

COMMENTS. This species does not occur in the Far East (but only in Middle Siberia) and is documented here for comparison with the other species.

BIOLOGICAL NOTES. This species occurs in humid habitats such as sphagnum bogs and the shores of lakes and streams.

DISTRIBUTION. This species has a Holarctic range and is known in the West Palaearctic (from Europe to Middle Siberia) and the Nearctic [Mikhailov, 1997; Dondale \& Redner, 2010].

\section{Piratula logunovi sp.n.}

Figs 4a, 80-91, 150-151, 161, 173, Map 3.

MATERIAL EXAMINED. Holotype $\sigma^{7}$ and paratypes $5 \sigma^{7} \sigma^{\top} 1$ क (ZMMU), RUSSIA, Maritime Prov., Gornotayozhnoye Village, 24.07.2007 (M.M. Omelko).

ETYMOLOGY. The specific name is a patronym in honour of our friend and colleague Dmitri V. Logunov (Manchester, UK).

DIAGNOSIS. This species is most similar to $P$. canadensis. Males of $P$. logunovi sp.n. can be easily distinguished from the latter by their larger body size, and thinner tip of the tegular apophysis, more slender cymbium (length/width ratio 1.83 as opposed to 1.57 in $P$. canadensis). All segments of the palps, femurs, distal parts of tibiae and lateral surfaces of patellae are dark grey or black. Females of $P$. logunovi sp.n. have a more distinct and dark carapace pattern than those of $P$. canadensis (grey marginal stripes). The epigynes of these two species are rather similar and are difficult to distinguish without extraction. In addi- 


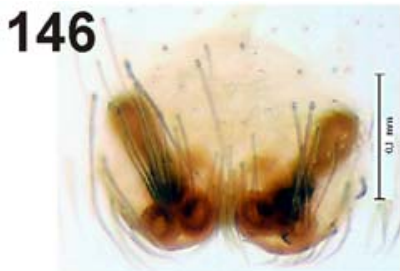

147

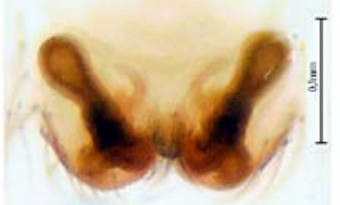

canadensis
150

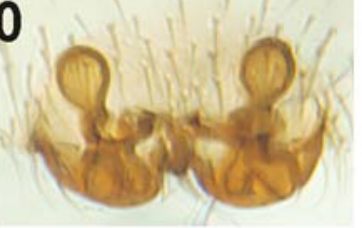

151

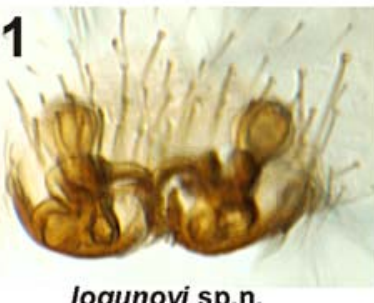

logunovi sp.n.

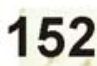

148

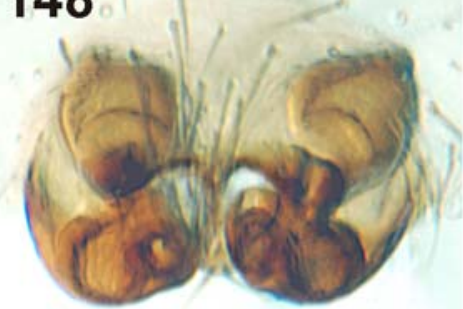

149

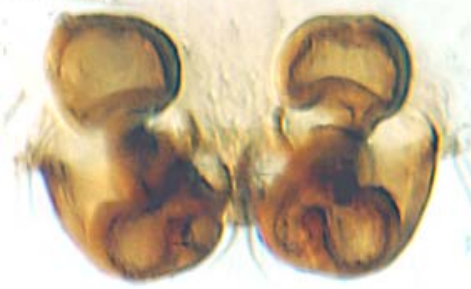

serrulata

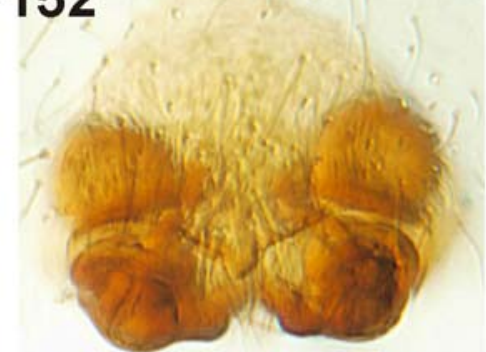

153

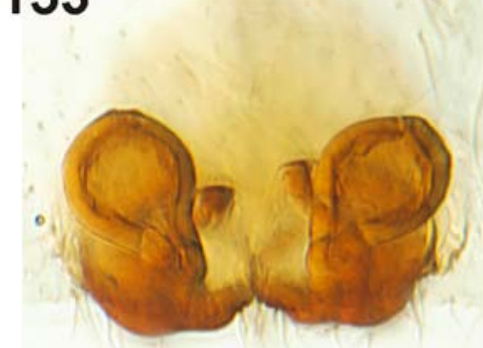

meridionalis

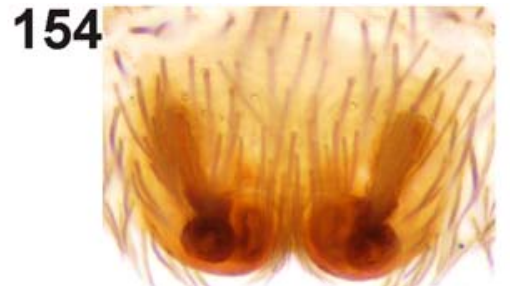

155

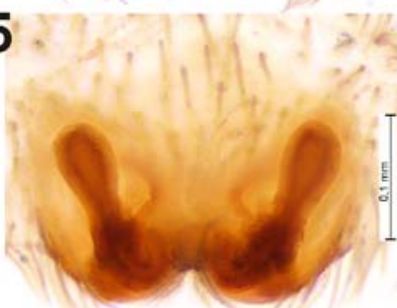

insularis
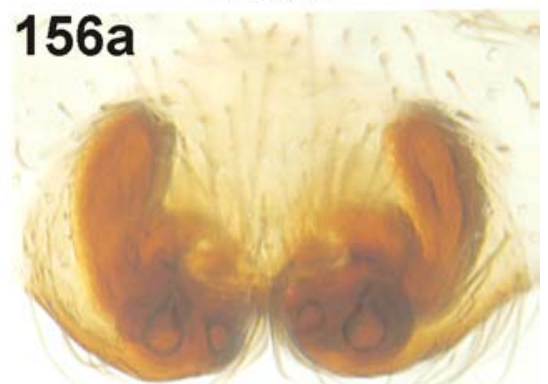

$156 b$

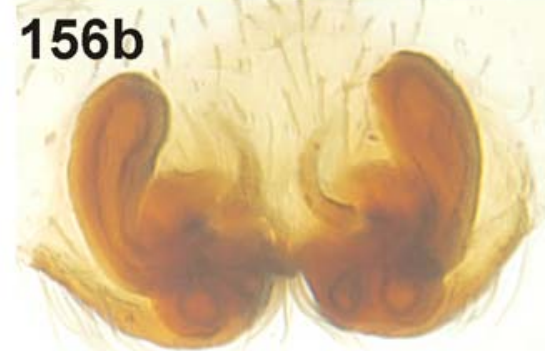

yaginumai

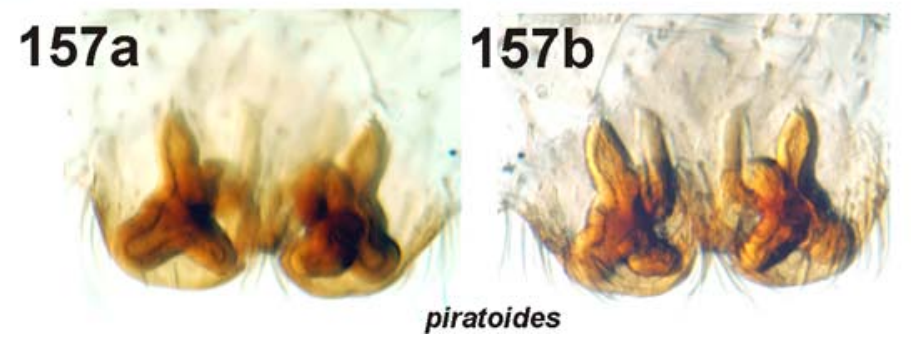

Figs 146-157. Epigyne and vulva of Piratula canadensis (146, 147), P. serrulata (148, 149), P. logunovi sp.n. (150, 151), P. meridionalis $(152,153)$, P. insularis $(154,155)$, P. yaginumai $(156 \mathrm{a}-\mathrm{b})$, , P. piratoides $(157 \mathrm{a}-\mathrm{b})$.

Рис. 146-157. Эпигина и вульва Piratula canadensis $(146,147)$, P. serrulata $(148,149)$, P. logunovi sp.n. (150, 151), P. meridionalis $(152,153)$, $P$. insularis $(154,155)$, P. yaginumai $(156 \mathrm{a}-\mathrm{b}), P$. piratoides $(157 \mathrm{a}-\mathrm{b})$.

tion, $P$. logunovi sp.n. is close to $P$. tanakai in coloration of the legs and body but is easily distinguished by the structure of the copulatory organs. P. logunovi sp.n. and $P$. canadensis differ from other congeners by their very small body size.

DESCRIPTION. Measurements. Male. Total length 4.1-4.5. Carapace: 1.85-2.08 long, 1.3-1.4 wide. Cara- pace/femur I length ratio 1.54-1.59. Leg I joints: $1.2+$ $0.5+1.05+1.1+0.6$.

Female. Total length 4.1. Carapace: 1.9 long, 1.35 wide. Carapace/femur I length ratio 1.36. Leg I joints: $1.4+0.55+1.0+1.05+0.55$.

Male. Carapace dark brown with yellow median band and submarginal stripes. Median band with dis- 
tinct V-mark. Marginal stripes dark. Eye field black. Clypeus and chelicerae brown. Maxilla and labium yellowish brown. Sternum greyish yellow with a light longitudinal stripe (Fig. 4a). Abdomen grey with pattern. Femur I with 3 dorsal spines and 1 prolateral; tibia with 1 prolateral, 1 retrolateral and 2-2 ventral; metatarsus with 2-2 ventral spines.

Palp as in Figs 80-82, 86-91. Tibia straight, slightly shorter than cymbium (Fig. 173). Tegular apophysis curved with thin tip, inner tooth wide, basal tooth absent. Terminal apophysis with ridge-like subterminal apophysis.

Female. Coloration of the body as in males but somewhat lighter. Femur I with 3 dorsal spines and 1 prolateral; patella without spines; tibia with 1 prolateral and 2-2 ventral; metatarsus with 2-2 ventral spines. Epigyne as in Figs 85, 150-151. Receptacula spherical.

BIOLOGICAL NOTES. Most of the specimens were collected by pitfall traps in a moist meadow. The maximum number of adult spiders occurs in June-July. Only females (many with cocoons) were observed in August.

DISTRIBUTION. Maritime Province of Russia only (Map 1).

Piratula meridionalis (Tanaka, 1974), comb.n.

Figs 4c-d, 92-101, 152-153, 165, 170, Map 3.

Pirata m. Tanaka, 1974: 31, f. 15-17 ( $\left.\sigma^{\top}+\right)$.

Pirata m: Tanaka, 1988: 52, f. 21-24 ( $\left.\sigma^{7}+\right)$.

Pirata m.: Chikuni, 1989: 114, f. 23 ( $\sigma^{\top}+$ ).

Pirata m.: Song et al., 1999: 344. f. 200I,U ( $\left(\sigma^{7}+\right)$.

Pirata m.: Tanaka, 2009: 225, f. 24-25 ( $\sigma^{7}+$ ).

For more references see Platnick [2011].

Faunistic records. Pirata meridionalis: Omelko [2006].

MATERIAL EXAMINED. RUSSIA, Maritime Prov.: $60^{7} \sigma^{7}$ (ZMMU), Lazovski Dist., Chukhunenko Lake, 20.07.2005 (M.M. Omelko); $121 \sigma^{7} \sigma^{\top} 24$ 우 (GTS), Lazovski Dist., Chukhunenko Lake, 10-25.07.2005 (M.M. Omelko); 2 ơ + (ZMMU), Khasanski Dist., Lotos Lake, 14.08.2004 (M.M. Omelko).

DIAGNOSIS. Males can be easily separated from other congeners except for $P$. borea by their modified tip of the tegular apophysis and curved tibia of the palp with thick retrolateral spines. The differences between $P$. meridionalis and $P$. borea are indicated in the diagnosis of the latter species. Females of $P$. meridionalis are similar to those of $P$. serrulata and $P$. logunovi sp.n. but differ by possessing a single retrolateral spine on femur I.

DESCRIPTION. This species was well described by Tanaka [1974, 1988]. Carapace and abdomen with pattern as in Figs 95-96. Marginal stripes dark brown, as wide as light yellow submarginal stripes, median band light yellow. Sternum dark brown with yellowish longitudinal stripe and three pairs of spots (Figs 4c-d). Abdomen brown with heart mark and a series of strokes and white spots in both sexes. Legs without annulations. Chaetotaxy of leg I as shown in Tables 1-2. Palp as in Figs 92-94, 98-101. Cymbial length/width ratio 1.68. Tibia curved with thick retrolateral spines, shorter than cymbium (Fig. 170). Tegular apophysis modified with rectangular inner tooth shifted towards tip of apophysis (Fig. 98). Basal tooth small (Fig. 98). Subterminal apophysis long and pointed unlike in other Piratula (Fig. 101). Epigyne and vulva as in Figs 97, 152, 153. Receptacula spherical.

COMMENTS. This species has an unusual conformation of the male palp (shape of tegular apophysis, sharply pointed "subterminal" apophysis, curved and thick palpal tibia) and may possibly belong in a separate genus.

BIOLOGICAL NOTES. This species is common and sometimes very numerous on the moist shores of lakes. In Japan it was observed living in small and scanty webs [Tanaka, 1988].

DISTRIBUTION. This species has a Far Eastern range and is known from Japan (Honshu), China, South Korea and Maritime Province of Russia.

Piratula piratoides (Bösenberg et Strand, 1906), comb.n.

Figs 2b, 102-113, 157a-b, 160, 171, Map 3.

Pirata p.: Tanaka, 1988: 49, f. 17-20 (○'o).

Pirata p.: Chikuni, 1989: 113, f. 20 (ठㅇ).

Pirata p.: Song et al., 1999: 344, f. 200L, 201C ( (

Pirata p.: Tanaka, 2009: 225, f. 22-23 ( $\mathrm{O}^{7}+$ ).

For more references see Platnick [2011].

MATERIAL EXAMINED. RUSSIA, Maritime Prov.: $1 \sigma^{7} 2$ of (ZMUT), Khanka Lake CW shore, Sosnovy Isl. \& peninsula nearby, $44^{\circ} 52^{\prime} \mathrm{N} 132^{\circ} 07^{\prime} \mathrm{E}, 17.07 .1998$ (Y.M. Marusik); 7 우 (ZMUT), Khanka Lake, S shore, Luzanova Sopka, $44^{\circ} 33^{\prime} \mathrm{N}$

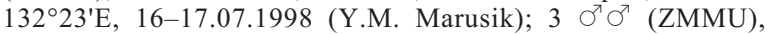
Khasanski Dist., Lotos Lake, 17-18.07.2004 (M.M. Omelko); 3 우 (ZMUT), Gornotayozhnoye Vil., 01.08.2003 (M.M. Omelko); 1 フ (ZMUT), Gornotayozhnoye Vil., 16.06.2007 (M.M. Omelko); 3 $\mathrm{O}^{\top} \mathrm{O}^{\top} 3$ 우 (GTS), Spasskii Dist., environs of Novoselskoe Vil., 1521.07.2005 (M.M. Omelko); $1 \sigma^{7} 2$ 우 (GTS), Lazovskii Dist., old mouth of Kievka River, 10-25.07.2005 (M.M. Omelko).

DIAGNOSIS. $P$. piratoides is most similar to $P$. yaginumai but has a smaller tegular apophysis with two additional teeth and laterally located subtegulum. Females of $P$. piratoides are easily distinguishable from other congeners by the shape of the epigyne and the structure of the vulva.

DESCRIPTION. This species was well described by Tanaka [1988]. Carapace and abdomen with pattern as in Figs 105-106. Marginal stripes dark brown. Submarginal stripes light, almost as wide as submedian bands, median band light brown. Eye arrangement as in Fig. 2b. Median row of eyes as wide as anterior. Abdomen brown with indistinct heart mark and series of light strokes. Legs without annulations. Chaetotaxy of leg I as shown in Tables 1-2. Palp as in Figs 102-104, 108-113. Cymbial length/width ratio 2.13. Tibia straight, shorter than cymbium (Fig. 171). Tegular apophysis curved with pointed tip; inner tooth mediumsized, basal tooth very long and thin with additional minute tooth located by its base (noticeable only from behind, Fig. 110). Subterminal apophysis ridge-like. Epigyne and vulva as in Figs 107, 157a-b. Receptacula small and elongate.

COMMENTS. This species is a new record for Russia, with previous records from China, South Korea and Japan. 

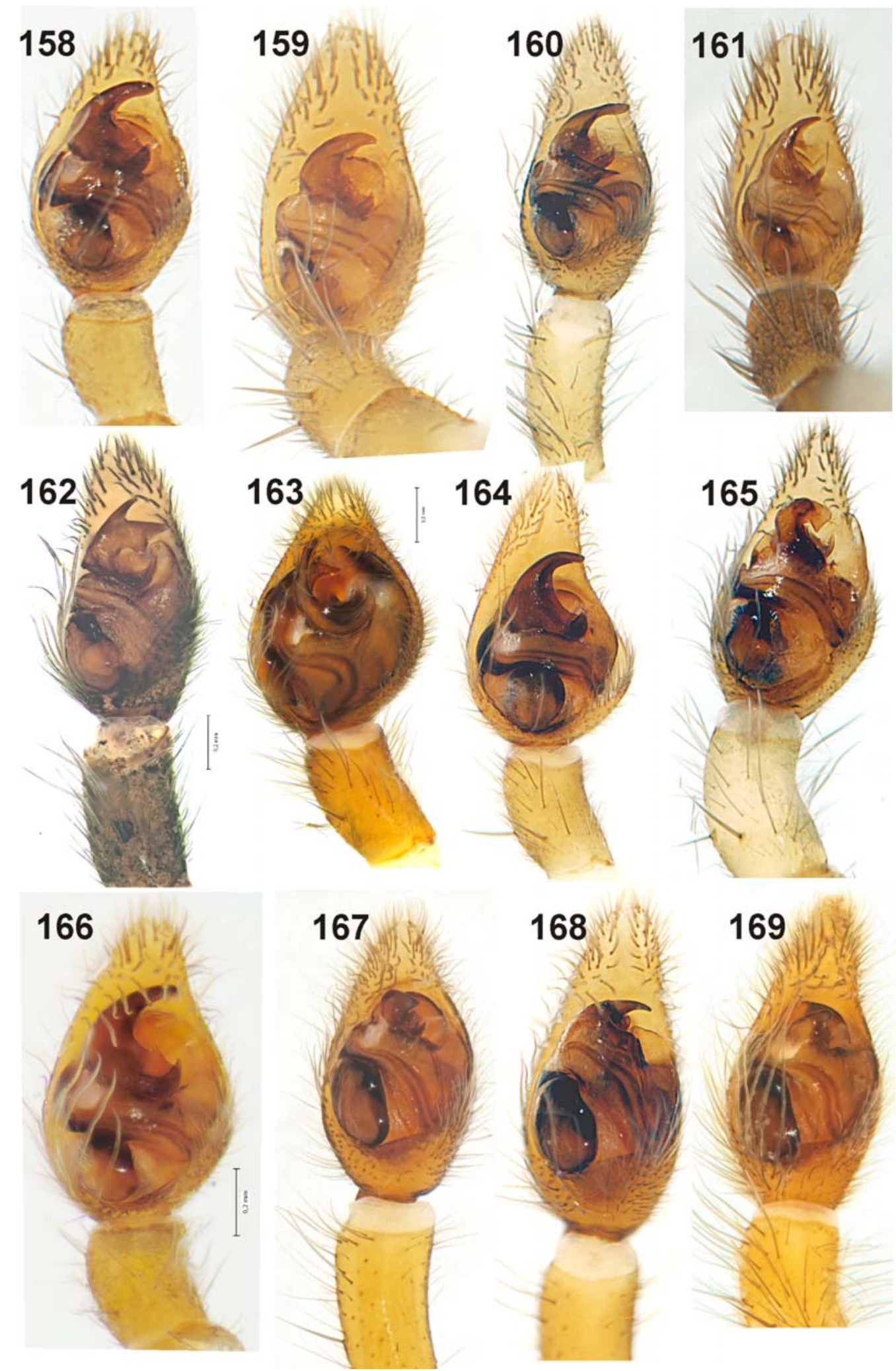

Figs 158-169. Palp of Piratula canadensis (158), P. serrulata (159), P. piratoides (160), P. logunovi sp.n. (161), P. tanakai (162), P. hygrophila (163), P. yaginumai (164), P. meridionalis (165), P. insularis (166), Pirata piraticus (167), P. subpiraticus (168), P. praedo (169).

Рис. 158-169. Пальпа Piratula canadensis (158), P. serrulata (159), P. piratoides (160), P. logunovi sp.n. (161), P. tanakai (162), P. hygrophila (163), P. yaginumai (164), P. meridionalis (165), P. insularis (166), Pirata piraticus (167), P. subpiraticus (168), $P$. praedo (169). 
BIOLOGICAL NOTES. This species occurs in various types of moist habitats such as lake shores, ponds and humid meadows.

DISTRIBUTION. This species has a Far Eastern range and is known from Japan (Honshu), China, South Korea and Maritime Province of Russia.

Piratula serrulata (Song et Wang, 1984), comb.n. Figs 5a, 114-123, 148, 149, 159, 172, Map 4.

Pirata serrulatus: Song et al., 1984: 149, f. 1-4 (○’ㅇ).

P. serrulatus: Logunov, 1992: 59, f. 5 ( ( $\left.{ }^{7}+\right)$

For more references see Platnick [2011].

MATERIAL EXAMINED. RUSSIA, Maritime Prov.: $1 \sigma^{7}$ (ZMMU), Khasanski Dist., Lotos Lake, 19.07.2004 (M.M. Omelko); $25 \sigma^{7} \sigma^{\top} 17$ 우 (GTS), Spasskii Dist., environs of Novoselskoe Vil., 15-21.07.2005 (M.M. Omelko); 4 ○ ○ $^{\top} 14$ 우 (ZMMU),

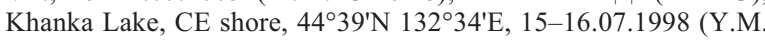
Marusik); $10^{7} 1$ 을 (ZMUT), Khanka Lake, S shore, Luzanova

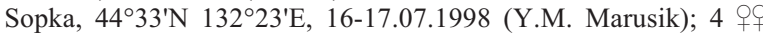
(ZMMU), Khanka Lake CW shore, Sosnovy Isl. \& peninsula nearby, $44^{\circ} 52^{\prime} \mathrm{N} 132^{\circ} 07^{\prime} \mathrm{E}, 17.07 .1998$ (Y.M. Marusik).

DIAGNOSIS. $P$. serrulata is most similar to $P$. logunovi sp.n. and P. canadensis. Males of P. serrulata differ from $P$. logunovi sp.n. by their thicker and shorter tegular apophysis and the light coloration of legs I and the palps. From $P$. canadensis it can be distinguished by its larger body size. Females of $P$. serrulata differ from both by possessing chitinized swellings on the lower part of the epigyne.

DESCRIPTION. Carapace and abdomen with pattern as in Figs 117-118. Marginal stripes dark brown. Submarginal stripes light, almost as wide as marginal stripes, submedian bands light brown. Sternum dark brown with yellowish longitudinal stripe and three pairs of spots (Fig. 5a). Abdomen brown with indistinct heart mark and a series of light strokes and spots. Legs without annulations. Chaetotaxy of leg I as shown in Tables 1-2. Palp as in Figs 114-116, 120-123. Cymbial length/width ratio 1.85 . Tibia straight, shorter than cymbium (Fig. 172). Tegular apophysis comparatively small, curved with pointed tip. Inner tooth short and broad with round tip, basal tooth with additional tooth located by its base (noticeable only from behind, Fig. 121). Subterminal apophysis ridge-like. Epigyne and vulva as in Figs 119, 148, 149. Receptacula spherical.

COMMENTS. This species was reported from Russia for the first time by Logunov [1992], from the environs of Khabarovsk.

BIOLOGICAL NOTES. The species occurs on lake shores and river banks.

DISTRIBUTION. This species has a Far Eastern range and is known from northeastern China (Heilongjiang Province) and in Far East Russia (Khabarovsk and Maritime Province).

Piratula tanakai (Brignoli, 1983), comb.n. Figs 124-135, 162, Map 4.

P. exiguus Tanaka, 1974: 37, f. 25-27 ( $\sigma^{7}+$, preoccupied by Banks [1892]).

Pirata t.: Tanaka, 1988: 61, f. 33-36 ( $\left.\mathrm{O}^{7}+\right)$.

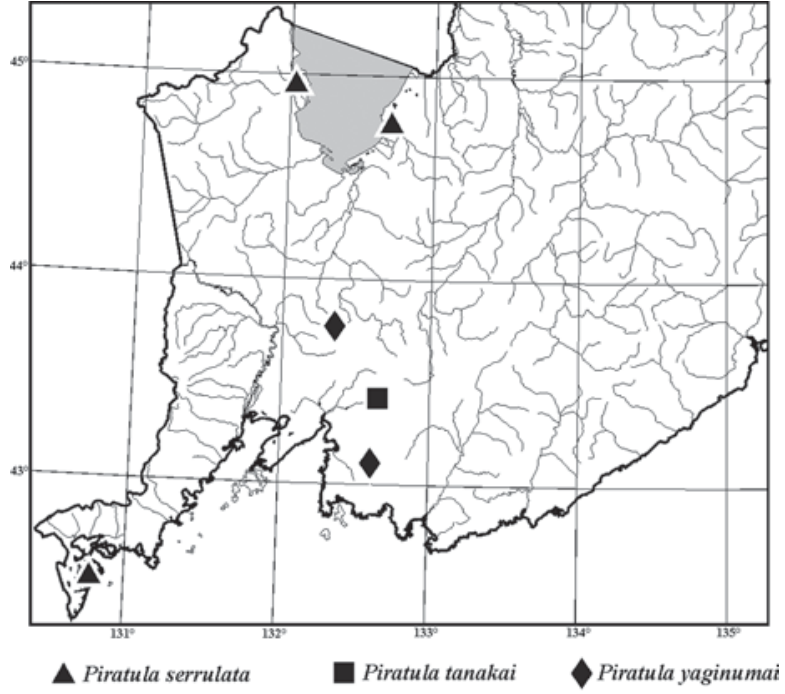

Map. 4. Distribution of species of Piratula in south Primorie: $P$. serrulata $(\mathbf{\Delta})$, P. tanakai $(\boldsymbol{\square})$ and $P$. yaginumai $(\boldsymbol{\bullet})$.

Карта 4. Распространение видов рода Piratula в южном Приморье: $P$. serrulata $(\boldsymbol{\Delta})$, P. tanakai $(\boldsymbol{\square})$ и $P$. yaginumai $(\diamond)$.

Pirata t.: Chikuni, 1989: 113, f. 22 (○'o).

Pirata t.: Tanaka, 2009: 227, f. 32-33 ( $\left.\sigma^{7}+\right)$.

For more references see Platnick [2011].

MATERIAL EXAMINED. RUSSIA, Maritime Prov.: $1 \sigma^{7}$ (ZMMU), Novaya Moskva Vil. environs, 02.07.2010 (M.M. Omelko).

DIAGNOSIS. $P$. tanakai has an unusual type of tegular apophysis and differs distinctly from others congeners except for $P$. yesoensis (Tanaka, 1985). Both sexes of $P$. tanakai can be distinguished by the presence of black markings on the patellae and tibia I.

DESCRIPTION. This species was well described by Tanaka [1988]. Carapace and abdomen with pattern as in Fig. 126. Marginal stripes dark brown, submarginal stripes yellowish, indistinct, submedian bands yellowish. Legs without annulations. Femur I and all segments of palp including lower part of cymbium blackish. Chaetotaxy of leg I as shown in Table 1. Palp as in Figs 124-125, 127-135. Cymbial length/ width ratio 2.13 . Tibia straight, shorter than cymbium. Tegular apophysis unusual for the genus with tip subdivided into three teeth (Figs 129-132). Basal tooth absent. Subterminal apophysis comparatively long with obtuse tip.

COMMENTS. The species is a new record for Russia, with previous records from Japan and South Korea.

BIOLOGICAL NOTES. The only male was collected on a pebble shore of a small stream. In Japan this species inhabits shores of streams also.

DISTRIBUTION. This species has a Far Eastern distribution and is known from Japan (Hokkaido and Honshu), South Korea and Maritime Province of Russia. 


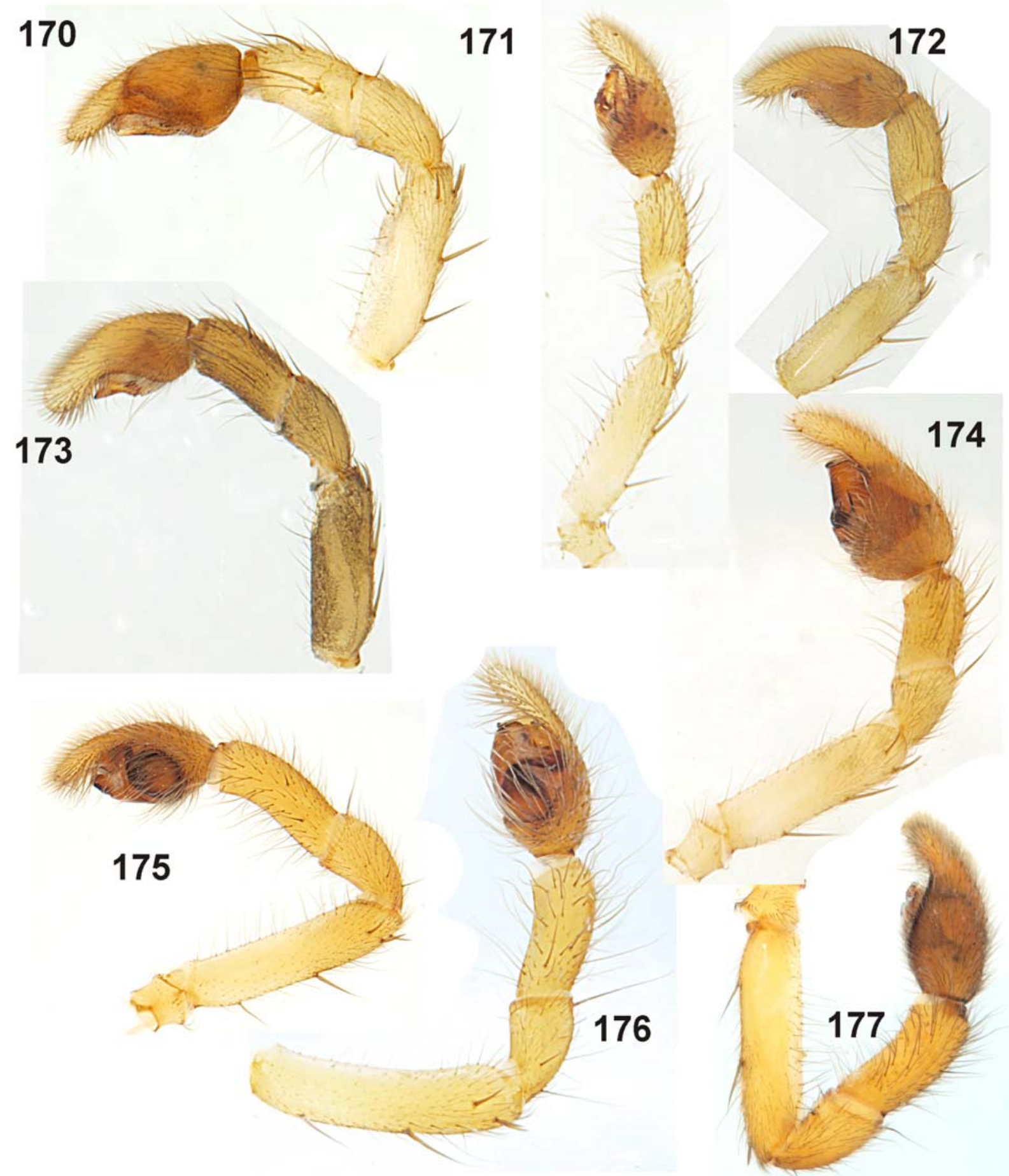

Figs 170-177. Whole palp of Piratula meridionalis (170), P. piratoides (171), P. serrulata (172), P. logunovi sp.n. (173), P. yaginumai (174), Pirata piraticus (175), P. subpiraticus (176), P. praedo (177).

Рис. 170-177. Целая пальпа Piratula meridionalis (170), P. piratoides (171), P. serrulata (172), P. logunovi sp.n. (173), P. yaginumai (174), Pirata piraticus (175), P. subpiraticus (176), P. praedo (177).

Piratula yaginumai (Tanaka, 1974), comb.n.

Figs 2c, 5b-c, 136-145, 156a-b, 164, 174, Map 4.

Pirata y. Tanaka, 1974: 27, f. 7-10 ( ( 7 + ).

Pirata y.: Tanaka, 1988: 46, f. 13-16 (ठ'i).
Pirata y.: Chikuni, 1989: 114, f. 24 (О'o).

Pirata y.: Song et al., 1999: 344, f. 200P, 201G (O'o).

Pirata y.: Tanaka, 2009: 225, f. 20-21 ( $\left.\sigma_{+}^{\top}\right)$

For more references see Platnick [2011].

MATERIAL EXAMINED. RUSSIA: Maritime Prov.: 1 \% (ZMUT), Gornotayozhnoye Vil., 11.06.2003 (M.M. Omelko); 2 우 

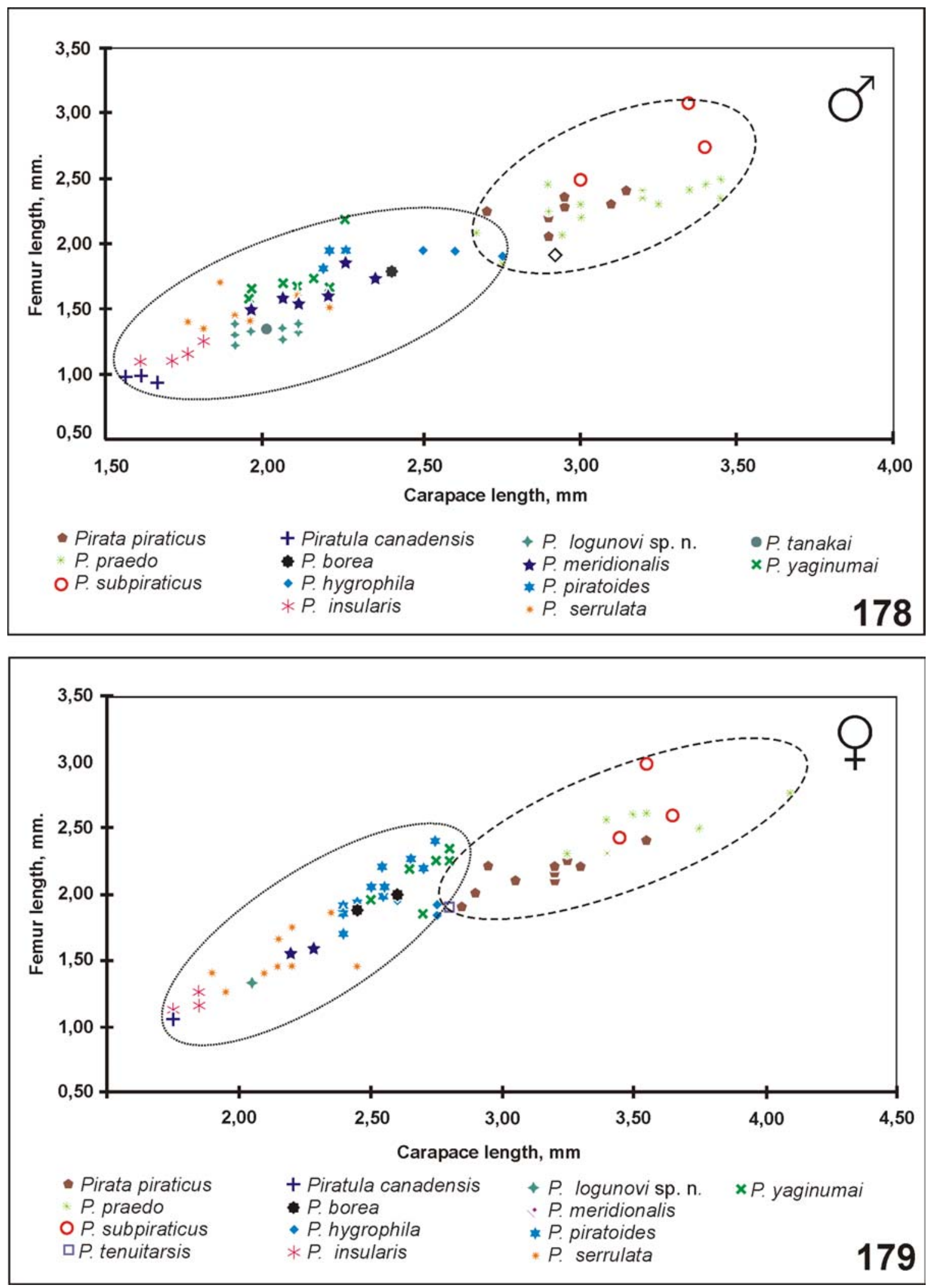

Figs 178-179. Diagrams showing carapace length / femur I length in males (178) and in females (179) in Pirata and Piratula. Рис. 178-179. Диаграммы показывающие соотношение длины карапакса и бедра I у самцов (178) и самок (179) разных видов Pirata и Piratula. 
(ZMMU), Gornotayozhnoye Vil., 21.08.2003 (M.M. Omelko); 1

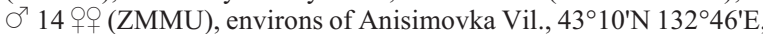
28.07.1998 (Y.M. Marusik). Sakhalin Area: $6 \sigma^{7} \sigma^{7} 7$ + 9 (ZMUT), Sakhalin Isl. SE part, W of Sokol Town, Malyi Takoi River, uppermiddle flow, $47^{\circ} 15.093^{\prime} \mathrm{N} 142^{\circ} 38.983^{\prime} \mathrm{E}, 20.07 .2001$ (Y.M. Marusik).

DIAGNOSIS. This species resembles $P$. piratoides. For differences between the males of these species, see the comments under the latter. Males of $P$. yaginumai differ distinctly from other Piratula species by lacking additional teeth on the tegular apophysis and in having the subtegulum located centrally.

DESCRIPTION. This species was well described by Tanaka [1974, 1988]. Carapace and abdomen with pattern as in Figs 139-140. Marginal stripes dark brown. Submarginal stripes light, almost as wide as marginal stripes. Median band light brown. Sternum dark brown with yellowish longitudinal stripe and three pairs of spots (Figs 5b-c). Eye arrangement as in Fig. 2c. Median row of eyes wider than anterior. Abdomen brown with heart mark and series of light strokes. Legs with distinct circles. Chaetotaxy of leg I as shown in Tables 1-2. Palp as in Figs 136, 137, 142-145. Cymbial length/ width ratio 1.59 . Tibia straight, shorter than cymbium (Fig. 174). Tegular apophysis curved with pointed tip. Inner and basal teeth absent. Subterminal apophysis ridge-like. Epigyne and vulva as in Figs 141, 156a-b. Receptacula elongate, large.

BIOLOGICAL NOTES. $P$. yaginumai occurs in moist habitats such as lake shores, ponds and humid meadows.

DISTRIBUTION. This species has a Far Eastern range and is known from Japan, China, South Korea. In Russia it is found in Sakhalin Island and Maritime Province.

ACKNOWLEDGMENTS. We wish to express our deep gratitude to our colleagues Hozumi Tanaka (Amagasakishi, Japan), Gergin Blagoev (Guelph, Canada), Charles D. Dondale (Ottawa, Canada) and Laimonas Trilikauskas (Uskuch, Russia) who provided us with comparative material. H. Don Cameron advised us about grammatic gender of Piratula and corrected the ending of the species names transferred from Pirata to Piratula. C.D. Dondale compared on our request our figures of $P$. praedo with Canadian specimens of $P$. zelotes. Special thanks go to Mykola Kovblyuk (Simpheropol, Ukraine) and to Dmitri Logunov (Manchester, UK) for their valuable comments on an earlier draft. Laura Leibensperger (MCZ) sent us holotype and allotype of Pirata zelotes. The English of the final draft was kindly checked by David Penney (Manchester, UK).

This work was supported in part by the RFFI grants \#\# 09-04-01365 and 11-04-01716-a.

\section{References}

Almquist S. 2005. Swedish Araneae, part 1: families Atypidae to Hahniidae (Linyphiidae excluded) // Insect Syst. Evol. Suppl. Vol.62. P.1-284.

Banks N. 1872. The spider fauna of the Upper Cayuga Lake Basin // Proc. Acad. nat. Sci. Philad. No.1892. P.11-81.

Barrion A.T, Litsinger J.A. 1995. Riceland Spiders of South and Southeast Asia. Wallingford: CAB International. 700 pp.
Chai B.Q. 1987. Two new species of the genus Pirata (Araneae: Lycosidae) // Acta zootaxon. sin. Vol.12. No.4. P.362-366.

Chamberlin R.V. 1908. Revision of North American spiders of the family Lycosidae// Proc. Acad. nat. Sci. Philad. Vol.60. P.158318.

Chikuni Y. 1989. Pictorial Encyclopedia of Spiders in Japan. Kaisei-sha Publ. Co. Tokyo. 310 pp.

Dondale C.D., Redner J.H.1981. Description of a new wolf spider in the genus Pirata (Araneae: Lycosidae) // Psyche. Vol.87. P.193-197.

Dondale C.D., Redner J.H. 1990. The insects and arachnids of Canada, Part 17. The wolf spiders, nurseryweb spiders, and lynx spiders of Canada and Alaska, Araneae: Lycosidae, Pisauridae, and Oxyopidae. Research Branch, Agriculture Canada. Publ. No.1856. 383 pp.

Eskov K.Y. 1988. [Aranei of Central Siberia] // Materialy po faune Srednei Sibiri i prilezhashchikh rayonov Mongolii. Moscow. P.101-155 [in Russian].

Heimer S., Nentwig W. 1991. Spinnen Mitteleuropas: Ein Bestimmungsbuch. Verlag Paul Parey. Berlin. 543 S.

Holm Å. 1947. Svensk Spindelfauna III. Oxyopidae, Lycosidae, Pisauridae. Stockholm. $48 \mathrm{~S}$.

Kronestedt T. 1980. Comparison between Pirata tenuitarsis Simon, new to Sweden and England, and P. piraticus (Clerck), with notes on taxonomic characters in male Pirata (Araneae: Lycosidae) // Entomol scand. Vol.11. P.65-77.

Logunov D.V. 1992. [On the spider fauna of the Bolshekhekhtsyrski State Reservation (Khabarovsk Province). I. Families Araneidae, Lycosidae, Philodromidae, Tetragnathidae and Thomisidae] // Sib. Biol. Zhurn. Vyp.4. P.56-68 [in Russian].

Marusik Yu.M. 2007. [Spiders (Arachnida: Aranei) of Asian part of Russia: taxonomy, fauna, zoogeography]. Doctoral thesis. St.Petersburg, St. Petersburg University. 335 pp. [in Russian].

Marusik Yu.M., Koponen S. 2000. New data on spiders (Aranei) from the Maritime Province, Russian Far East // Arthropoda Selecta. Vol.9. No.1. P.55-68.

Marusik Yu.M., Logunov D.V., Koponen S. 2000. Spiders of Tuva, South Siberia. IBPN FEB RAS, Magadan. 252 pp.

Marusik Yu.M., Omelko M. M., Koponen S. 2010. A survey of the east Palearctic Lycosidae (Aranei). 5. Taxonomic notes on the easternmost Palearctic Pirata species and on the genus Piratosa Roewer, 1960 // Arthropoda Selecta. Vol.19. No.1. P.29-36.

Nadolny A.A., Kovblyuk M.M. 2011. The spider genus Pirata Sundevall, 1833 (Aranei, Lycosidae) in Crimea and Abkhazia // Arthropoda Selecta. Vol.20. No.3. P.175-194.

Omelko M.M. 2006. [Biological and faunistic survey of the wolf spiders (Aranei, Lycosidae) from environs of marine field station "Zapovednoe" (South Primirye)] // Chtenyia pamyati A.I. Kurentsova. Vladivostok: Dalnauka. Vyp.17. P.128-133 [in Russian].

Paquin P., Dupérré N. 2003. Guide d'identification des araignées de Québec // Fabreries, Suppl. Vol.11. P.1-251.

Roberts M.J. 1995. Collins Field Guide: Spiders of Britain \& Northern Europe. London: Harper Collins. 383 pp.

Roberts M.J. 1998. Spinnengids. Tirion, Baarn, Netherlands. 397 pp.

Roewer C.F. 1960. Araneae Lycosaeformia II (Lycosidae) (Fortsetzung und Schluss) // Explor. Parc natn. Upemba Miss. G. F. de Witte. Fasc.55. P.519-1040.

Song D.X., Wang H. 1984. A new species of the genus Pirata (Araneae: Lycosidae) // Acta zootaxon. sin. Vol.9. No.2. P.149-150.

Song D.X., Zhu M.S., Chen J. 1999. The spiders of China. Shijiazhuang: Hebei Sci. Technol. Publ. House. 640 pp.

Tanaka H. 1974. Japanese wolf spiders of the genus Pirata, with descriptions of five new species (Araneae: Lycosidae) // Acta arachnol. Vol.26. No.1. P.22-45.

Tanaka H. 1988. Lycosid spiders of Japan I. The genus Pirata Sundevall // Acta arachnol. Vol.36. No.1. P.33-77.

Tanaka H. 1995. A new species of the genus Pirata Sundevall (Araneae: Lycosidae) from Japan // Acta arachnol. Vol.44. No.1. P.47-49.

Tanaka H. 2009. Lycosidae // Ono H. (ed.). The Spiders of Japan with keys to the families and genera and illustrations of the species. Kanagawa: Tokai Univ. Press. P.222-248. 
Wallace H.K., Exline H. 1978. Spiders of the genus Pirata in North America, Central America and the West Indies (Araneae: Lycosidae) // J. Arachnol. Vol.5. No.1. P.1-112.

Yin C.M. 1978. [A study on the general orb-weaver spiders and wolf-spiders (Araneae: Araneidae, Lycosidae) from rice fields] // J. Hunan Teacher's Coll. Vol.10. P.1-21.
Zyuzin A.A. 1985. [Generic and subfamilial criteria in the systematics of the spider family Lycosidae (Aranei), with the description of a new genus and two new subfamilies] // Fauna I ekologiya paukov SSSR. Trudy Zool. Inst. AN SSSR. Leningr. T.139. P.40-51 [in Russian].

Responsible editor K.G. Mikhailov 